\title{
Doorwerking van het gemeen contractenrecht in het vennootschappelijk rechtspersonenrecht
}

Koen Geens \& Marieke Wyckaert*

\section{Inleiding: de contractuele versus de institutionele visie}

I. Situering - De vraag naar de doorwerking van het gemeen contractenrecht in het vennootschapsrecht behoeft naar Belgisch recht wat herformulering in die zin dat de maatschap, hoewel zij pas kort geleden (I999) haar plaats heeft gevonden in het Wetboek van vennootschappen (W.Venn.), in wezen nog steeds een contract is, in alle betekenissen van het woord. Het vennootschapsrecht in brede zin omvat in Boek II van het wetboek een aantal Napoleontische bepalingen van gemeen recht die in de eerste plaats de maatschap gelden, maar principieel algemeen vennootschappelijke toepassing vinden (artikel ig W.Venn.), terwijl het vennootschapsrecht in een engere betekenis enkel op de vennootschappelijke rechtspersonen doelt. De vraag is dus eigenlijk in welke mate het gemeen contractenrecht, waaronder met name gemeld Boek II, doorwerkt in het rechtspersonenrecht. Daarbij is het de Belgische preadviseurs niet ontgaan dat het Nederland op dit ogenblik vooral te doen is om de kwestie of allerlei extra-statutaire overeenkomsten de wettelijke en statutaire regels van de betrokken rechtspersoon terzijde kunnen stellen, of in ieder geval parallel daarmee uitwerking kunnen krijgen.

Dit probleem is de Belgen op het stuk van stem- en overdrachtsbeperkende overeenkomsten enigszins vertrouwd, maar het heeft niet de Nederlandse graad van acuutheid bereikt, omdat de recente globale tendens van flexibilisering van het vennootschapsrecht de klassieke cartesiaanse indelingen in België nog niet ter discussie heeft gesteld.

Het komt ons voor dat deze flexibiliseringstendens op de eerste plaats het voordeel van de beperkte aansprakelijkheid aan minder stringente voorwaarden wil onderwerpen. Daarvoor moet in het vennootschapsrecht een van twee heilige huisjes worden gesloopt. Ofwel geeft men aan de vennoten van een of ander type van personenvennootschap (bijvoorbeeld de V.O.F.) heel atypisch de beperkte aansprakelijkheid: er is dan sprake van een LLP of een limited liability partnership. Ofwel maakt men van

* Koen Geens \& Marieke Wyckaert zijn verbonden aan het Jan Ronse Instituut voor Vennootschaps- en Financieel recht, KU Leuven. 
de BVBA een verkapte personenvennootschap, en ontzegt men de derden die met dergelijke vennootschap handelen de kapitaalbescherming (met mogelijke compensatie in bijvoorbeeld het aansprakelijkheidsrecht of het insolventierecht) en aan de vennoten zelf de dwingende werking van een aantal meer 'institutionele' regels: men komt dan tot een LLC of limited liability company.

Zoals gezegd heeft België op dit stuk nog geen cruciale stappen gezet. Er is weliswaar de starters-BVBA voor beginnende ondernemers. Zij krijgen gedurende maximaal vijf jaar een light vehicle-regime op het vlak van kapitaal. ${ }^{.}$Tot een ingrijpende wijziging zoals de Nederlandse die de bv aftuigt, en maakt tot een 'one size fits all', dat is alles behalve de kleine zus van de NV, kwam het in België vooralsnog niet. ${ }^{2}$

Het is dus voor de Belgische preadviseurs gemakkelijker om afstand te bewaren ten aanzien van het thema van de doorwerking van het gemeen contractenrecht in het vennootschapsrecht, dan voor de Nederlandse collega's, omdat de BVBA naar Belgisch recht nog steeds als een besloten kapitaalvennootschap wordt aangezien, en zij nog niet de verregaande contractualisering heeft doorgemaakt van de Nederlandse bv.

2. Enkele weetjes vooraf: Belgische eigenaardigheden - In België is het onderscheid tussen personen- en kapitaalvennootschappen, hoewel descriptief en niet constitutief van aard, steeds zeer instructief geweest. ${ }^{3}$ Het wordt gemaakt volgens drie klassiek geworden criteria. Kapitaalvennootschappen worden niet aangegaan uit aanmerking van de persoon: hun geldigheid bij oprichting en hun voortbestaan worden dus in geen geval in het gedrang gebracht door gebreken of elementen van discontinuïteit op het niveau van de oprichters of de leden, terwijl de personenvennootschap bij oprichting staat (dat wil zeggen geldig of nietig is) en bij discontinuïteitselementen valt (dat wil zeggen wordt ontbonden) met ieder van de vennoten. Bovendien verloopt de besluitvorming in de kapitaalvennootschappen bij meerderheid, en niet bij unanimiteit, zoals in een personenvennootschap. Ten slotte is de overdracht van aandelen mogelijk in de kapitaalvennootschap, terwijl deze in een personenvennootschap in beginsel is uitgesloten.

Merkwaardig genoeg maakt het criterium van de (on)beperkte aansprakelijkheid geen deel uit van het onderscheid. Het betreft immers de verhouding met derden, en niet die tussen de vennoten onderling. Toch is impliciet in het onderscheid dat de personenvennootschap de onbeperkte aansprakelijkheid van de vennoten in het

Zie bijvoorbeeld C. Clottens en S. De Dier, 'De S-BVBA: een Minerva-light?', in: Overzicht wetgeving vennootschappen 2007-2011, Antwerpen: Biblo 20II, p. II-45.

2 Op I3 september 2013 keurde de Ministerraad wel een voorontwerp goed, waarbij de S-BVBA eerder naar een volwaardig en permanente light vehicle toe evolueert, maar de voorgestelde wijzingen blijven beperkt.

3 K. Geens en M. Wyckaert, m.m.v. C. Clottens, F. Parrein en S. De Dier, 'Verenigingen en vennootschappen - Deel II - De Vennootschap, A. Algemeen deel', in: Beginselen van Belgisch privaatrecht, Mechelen: Kluwer 201 (verder aangehaald als Algemeen deel), nr. 86 e.v., p. 158 e.v. 
gedrang brengt, terwijl de leden van een kapitaalvennootschap hun aansprakelijkheid beperken tot de inbreng.

De NV is uiteraard de archetypische kapitaalvennootschap, zoals de maatschap het paradigma van de personenvennootschappen is. In België wordt de BVBA omwille van de geldende wettelijke overdrachtsbeperkingen ook wel besloten kapitaalvennootschap genoemd. ${ }^{4}$ De V.O.F. en de Comm.V. zijn dan weer personenvennootschappen.

Als meestal meerzijdige ${ }^{5}$ rechtshandeling is de vennootschap dubbel: er is de vennootschap als momentane rechtshandeling waarbij de verschillende vennoten hun toestemming geven om met de vennootschap van wal te steken; maar er is ook de precies aan die wilsovereenstemming ontspruitende vennootschap als langdurige verhouding tussen partijen en veelal ook als 'openbare' verhouding ten aanzien van derden.

Ook hier is er een wezenlijk onderscheid tussen personen- en kapitaalvennootschappen. De personenvennootschap is een contract in twee tijden: zij is een contract bij de oprichting, en blijft dat gedurende haar bestaan; de contractanten blijven elkaars 'partner'. Voor de kapitaalvennootschap is de meerderheidsopvatting aangevoerd door Ronse ${ }^{6}$ dat zij als rechtspersoon weliswaar haar ontstaan dankt aan een zogenoemde oprichtingsovereenkomst, maar dat de oprichters nadien lid zijn van dezelfde rechtspersoon, en onderling geen contractuele verhouding van 'partnership' hebben. Hebben zij nog een contractuele verhouding, dan is het met de rechtspersoon.

4 Anders dan de insteek van onze Nederlandse collega's, zullen wij eerder focussen op de naamloze vennootschap. De BVBA heeft dan wel recent de NV ingehaald als meest opgerichte vennootschapsvorm (D. Vivet, 'Resultaten en financiële situatie van de ondernemingen in 20Io', Economisch Tijdschrift 20II, 80), maar de NV blijft in de praktijk de meest gehanteerde vennootschapsvorm om het vennootschapsleven door contractueel maatwerk een aangepaste vorm te geven (bijvoorbeeld in een joint venture, in een familiale constellatie, in een private equity-omgeving). De BVBA is daarvoor voorlopig minder geschikt (zeker in vergelijking met de geflexibiliseerde bv) omdat zij op het vlak van winstrechten weinig plooibaarheid toont (zie art. 275 W.Venn.), en haar beslotenheid nog vrij letterlijk te nemen valt (zie verder nr. 35). De CVBA is - eerder uit onbeslistheid van de wetgever over waarmee hij precies met die CVBA naartoe wilde dan uit bewuste keuze - de vennootschapsvorm die theoretisch de grootste contractuele vrijheid biedt (zie bijvoorbeeld J. Wouters, 'De coöperatieve vennootschap als alternatief voor de naamloze vennootschap?', in: IBJ (red.), Tendensen in het bedrijfsrecht - 3-Vennootschappen - nieuwe technologieën-bankrecht-mededinging, Brussel/Antwerpen: Bruylant/Kluwer 1992, p. 45-I27), maar wordt uit angst voor het onbekende en twijfel over de grenzen van de flexibiliteit niet massaal gebruikt. Omdat de aangewende contractuele technieken nauw aansluiten bij die van de NV, en het wettelijk kader van het contractueel maatwerk in de NV het best is geregeld, is het voor een goede verkenning van de impact van het privaatrecht op het vennootschapskader niet onontbeerlijk om ons ook op de CVBA toe te spitsen. Een tweede reden om niet op de CVBA in te gaan, is dat zij naar Nederlands recht vereniging is.

5 Vgl. H. De Page, Traité élémentaire de droit civil, Brussel: Bruylant II ig64, nr. 447, p. 409; M. Planiol en G. Ripert, Traité pratique de droit civil français, VI, Parijs: L.G.D.J. 1952, nr. I3, p. I7; E. Dirix, 'De meerpartijenovereenkomst', TPR I983, 759, nr. 4 en 766 , nr. II.

6 Deze vertoont sterke verwantschap met die van Meijers aangehaald in het rapport van de Nederlandse preadviseurs onder nr. ATV. 
De drie klassieke verschilpunten tussen personen- en kapitaalvennootschappen zijn precies terug te brengen op het gegeven dat de personenvennootschap ook gedurende haar bestaan een contract blijft: het wegvallen van een contractspartner, zijn vervanging door een andere of een contractswijziging verlopen daar volgens het geëigende contractuele regime; beter gezegd, contracten zijn niet gemaakt voor dat soort voorvallen, en hebben dus niet de flexibiliteit die daarvoor in een kapitaalvennootschap wordt geboden.

Hoe dan ook is duidelijk dat de aanleiding tot verdubbeling van afspraken in statuten enerzijds en overeenkomsten anderzijds in een personenvennootschap veel geringer is dan in een kapitaalvennootschap.

Door de beslotenheid en het geringe aantal vennoten leidt een overdracht van een participatie door een uittredende vennoot aan een nieuwe vennoot vanzelfsprekend tot een aanpassing van de basisvennootschapsovereenkomst. Zij kan daarom alle afspraken integreren. Afspraken op de achtergrond waarbij niet alle vennoten partij zijn, zijn eerder zeldzaam. Croupier-overeenkomsten en stille maatschappen van één vennoot met derden die niet mogen toetreden van de andere vennoten kaart de wetgever dan weer zelf aan (artikel 38 W.Venn.).

In een kapitaalvennootschap daarentegen zijn er meer partijen, en impliceert de overdraagbaarheid van aandelen door een lid aan een derde, buiten de instemming van de vennootschap en de andere leden om, dat deze derde moet kunnen toetreden tot de statutaire afspraken zonder meer. Mede omwille van de mogelijke verhoudingen tussen meerderheid en minderheid, kunnen afspraken tussen bepaalde partijen buiten de statuten om in dat geval aangewezen zijn.

Het gemaakte onderscheid tussen personen- en kapitaalvennootschappen geldt naar Belgisch recht op eigenzinnige, onvolkomen wijze voor de V.O.F. en de Comm.V., en zulks anders dan in Nederland waar V.O.F. en Comm.V. volledig het regime van de maatschap volgen. Zijn in een Belgische V.O.F. of Comm.V. de vennoten ook na de oprichting elkaars partner, en blijven zij dus in die zin contractueel in de tweede tijd, dan vertonen deze vennootschappen niettemin een aspect van rechtspersoonlijkheid naar derden toe: de zaakvoerders vertegenwoordigen inderdaad een rechtspersoon en niet de gezamenlijke vennoten, ook al zijn die op onbeperkte wijze aansprakelijk voor de vennootschapsschulden. Men zou kunnen zeggen dat de V.O.F. en de Comm.V. daarom slechts semicontractuele personenvennootschappen zijn. Toch is het onderscheid met de maatschap vooral een kwestie van publicatie of kenbaarheid voor derden: de maatschap is aan geen enkele publicatie- of jaarrekeningverplichting onderworpen, de oprichtingsakte van V.O.F. en Comm.V. moeten daarentegen bij uittreksel worden opgenomen in het Belgisch Staatsblad (artikel 68-69 W.Venn.) en zij zijn in beginsel onderworpen aan de jaarrekeningplicht (artikel 92-93 W.Venn.). De belangrijkste consequentie daarvan is dat de zaakvoerders de bevoegdheidsbeperkingen die zij lijden niet moeten voorleggen aan de wederpartij om ze tegenwerpelijk te maken, zoals dat in een maatschap het geval is door toepassing van de regels van de lastgeving. Maar de vertegenwoordiging zelf kan 
door publicatie in het Staatsblad in elk opzicht op aan derden tegenwerpelijke wijze worden beperkt, terwijl in een NV of een BVBA natuurlijk het Prokurasysteem geldt dat dergelijke statutaire beperkingen precies niet-tegenwerpelijk maakt aan derden te goeder trouw (artikel 257 en 522 W.Venn.).

Overigens is het verschil tussen de vennootschappen zonder rechtspersoonlijkheid en die met rechtspersoonlijkheid maar zonder beperkte aansprakelijkheid verwaarloosbaar: met name de continuïteit die zo typisch wordt geacht voor de rechtspersoon ontbreekt grotendeels in de onvolkomen rechtspersoon, ${ }^{7}$ terwijl het afgescheiden vermogen waarvan men zou denken dat het ontbreekt in de vennootschap zonder rechtspersoonlijkheid daar niettemin voorhanden is. ${ }^{8}$

Het is de lege ferenda zonder meer verkieslijk dat de wetgever de vennootschappen zonder en die met onvolkomen rechtspersoonlijkheid over een kam zou scheren. ${ }^{9}$ Het Nederlandse ontwerp personenvennootschappen dat zojuist en net vóór de eindstreep faalde, kan daarbij als inspirerend voorbeeld dienst doen.

3. De totstandkoming van de rechtspersoon naar Belgisch recht: een oprichtingsovereenkomst in de eerste tijd, lidmaatschapsverhoudingen in de tweede tijd - De vraag naar de aard van de oprichtingshandeling zou het debat over de doorwerking van het gemeen contractenrecht kunnen vertroebelen. Het antwoord erop zal aantonen dat de kwestie van secundair belang is. De doorwerking doet immers haar intrede na de oprichting. Niettemin moet het vraagstuk kort worden aangesneden.

De Belgische wetgever volgde bij de codificatie van het vennootschapsrecht in 1999 de opvatting van Ronse dat de rechtspersoon tot stand komt door een overeenkomst tussen de oprichters, ${ }^{\text {Io }}$ althans voor zover de oprichtingsakte ook effectief wordt neergelegd (artikel I W.Venn.). Deze bepaling laat de Belgische meerderheidsopvatting duidelijk tot zijn recht komen.

7 Geens en Wyckaert, Algemeen deel, nr. 403, p. 689.

8 J. Vananroye, Onverdeelde boedel en rechtspersoon als technieken van vermogensafscheiding en vermogensovergang (doctoraatsthesis KU Leuven), 20II, nr. I-6, p. I-4; Geens en Wyckaert, Algemeen deel, nr. I72, p. 323.

9 Geens en Wyckaert, Algemeen deel, nr. 9, p. I8-r9.

Io In die zin: België: L. Frédéricq, Traité de droit commercial, Gent: Féchyer, IV, I950, nr. 6, p. 6o e.v.; L. en S. Frédéricq, Handboek van het Belgisch handelsrecht, Brussel: Bruylant, I, I962, nr. 496, p. 430; C. Resteau, A. Benoit-Moury en A. Gregoire, Traité des sociétés anonymes, Brussel: Swinnen (verder aangehaald als Traité), I, I98I, nr. 8, p. 39 e.v.; M. Coipel, 'La théorie de l'engagement par volonté unilatérale', noot onder Cass. I8 december I974, RCJB I980, 87; H. Laga, Statuten, statutenwijziging en reglement van inwendige orde getoetst aan algemene beginselen van contractenrecht. Een toepassing op de coöperatieve vennootschap (doctoraatsthesis KU Leuven), I99I, p. II-I2; M. Wyckaert, Kapitaal in N.V. en B.V.B.A., Antwerpen: Biblo 1995 (verder aangehaald als Kapitaal in N.V. en B.V.B.A.), nr. 29-38, p. 46-52; Frankrijk: J. Hamel en G. Lagarde, Traité de droit commercial, I, Parijs: Dalloz I954, nr. 385 , p. 469; J. Hemard, F. Terre en P. Mabilat, Sociétés commerciales, Parijs: Dalloz I972, nr. 65I e.v., p. 594, inz. nr. 659, p. 598; Nederland: A. Pitlo en M.J.G.C. Raaijmakers, Vennootschaps- en rechtspersonenrecht, Deventer: Gouda Quint 2000, nr. 2.39, p. I35; M.J.G.C. Raaijmakers, Joint ventures: enkele beschouwingen omtrent het rechtskarakter en de concernbetrekkingen van de gemeenschappelijke dochteronderneming (diss. Tilburg), Deventer: Kluwer i976, p. II6 e.v.). 
Het feit dat een overeenkomst tegelijkertijd een rechtspersoon tot stand brengt (Organisationsvertrag, Vereinbarung), ${ }^{\mathrm{II}}$ tegenover wie de vennoten-oprichters rechten verkrijgen en verplichtingen opnemen, is niet merkwaardiger dan de overeenkomst waaruit de verbintenis ontstaat om een bepaalde zaak te leveren en die het zakenrechtelijk effect van eigendomsoverdracht tot gevolg heeft. ${ }^{12}$

Samen met de oprichting stellen de oprichters de statuten vast volgens welke de rechtspersoon zal functioneren en, in voorkomend geval, benoemen zij ook de bestuurders van de vennootschap in de oprichtingsakte. Uit de statuten volgen voor de rechtspersoon verplichtingen van contractuele aard jegens zijn leden, een en ander binnen de perken getrokken door de dwingendrechtelijke bepalingen die de door de oprichters gekozen rechtsvorm beheersen. Deze dwingendrechtelijke bepalingen vloeien voort uit de beperkte aansprakelijkheid van de vennoten, en meer bepaald uit de door wetgever als noodzakelijk beschouwde bescherming van de derden die alleen kunnen rekenen op het vermogen van die rechtspersoon.

Het typische aan de oprichtingsovereenkomst in de volkomen rechtspersoon is dus dat, anders dan in een gewone verbintenisscheppende overeenkomst, de partijen niet jegens elkander verbintenissen aangaan, ${ }^{13}$ maar jegens de rechtspersoon zelf. ${ }^{14}$ Het is alsof de rechtspersoon, hoewel geen partij bij de oprichtingsovereenkomst, toch op hetzelfde moment door zijn oprichters wordt vertegenwoordigd. In de oprichtingsovereenkomst verbinden de oprichters zichzelf als leden jegens de rechtspersoon en de rechtspersoon jegens zijn leden, zoals zij hem in het algemeen door de in de oprichtingsakte vervatte statuten verbinden. De rechtsgevolgen van de oprichtingshandeling worden aan de rechtspersoon toegerekend. In wezen gaan de oprichters jegens elkaar geen andere verbintenissen aan dan de verbintenis om de rechtspersoon op te richten, dit is de eerste betekenis van de oprichtingsovereenkomst. Enkel in de relatie tot de rechtspersoon, die uit de overeenkomst ontstaat, worden voortdurende verbintenissen geschapen, in de tweede betekenis van de oprichtingsovereenkomst. Het belang van deze eerste betekenis van de oprichtingsovereenkomst is dus sterk gereduceerd. ${ }^{15}$

II Vgl. o.m. H. Würdinger, Aktien- und Konzernrecht, Karlsruhe: Müller I973, par. I8, p. 89 e.v.; G. Hueck, Gesellschaftsrecht, Munchen: Beck I99I, par. 6, p. 46; H. Lehmann en R. Dietz, Gesellschaftsrecht, Berlijn: Vahlen I970, par. 5, p. 45 e.v.; R.Reinhardt en D. Schultz, Gesellschaftsrecht, Tübingen: Mohr I98I, nr. 53, p. 33 .

I2 J. Hamel, 'Quelques réflexions sur le contrat de société', in: Mélanges à lahonneur de Jean Dabin, II, Brussel: Bruylant ig65, p. 656.

I3 De uitzonderingssituatie van het beding ten behoeve van een derde (art. II2I B.W.) buiten beschouwing gelaten.

I4 Resteau e.a., Traité, I, I982, nr. 503, p. 304; W.L.P.A. Molengraaff, Leidraad bij de beoefening van het Nederlandsche Handelsrecht, I, Haarlem: Bohn I930, p. 249.

I5 Maar niet onbestaande. Het verklaart immers waarom ook de deelneming aan de oprichtingshandeling voor nietigverklaring in aanmerking komt of zelfs aanleiding kan geven tot schadeloosstelling, bijvoorbeeld bij incidenteel bedrog door een medeoprichter (Geens en Wyckaert, Algemeen deel, nr. 44 e.v. (inz. nr. 48), p. 86 e.v.). 
Pleidooien om de oprichting van een rechtspersoon niet als overeenkomst te beschouwen maar, zoals in Nederland, als een meerzijdige rechtshandeling sui generis, ${ }^{16}$ compliceren de zaken voor België nodeloos, omdat, zoals hiervoor (nr. 2) aangeduid, in België de V.O.F. en de Comm.V. worden beschouwd als zogenoemde onvolkomen rechtspersonen met een semicontractueel karakter. Het zou immers paradoxaal zijn dat de oprichting van een onvolkomen rechtspersoon wel, en die van een volkomen rechtspersoon niet-contractueel zou zijn.

4. De institutionele verleiding: geen contract of meerzijdige rechtshandeling sui generis maar een eenzijdige toetreding? - Uiteraard kan de oprichting van een eenhoofdige vennootschap, zoals de eenpersoons-BVBA, geen contract zijn. ${ }^{17}$ Haar oprichting kan enkel het gevolg zijn van een eenzijdige wilsverklaring. Het wordt algemeen aanvaard dat de eenzijdige wilsverklaring verbindende kracht heeft. ${ }^{18}$ Men kan die verbindende kracht geredelijk aannemen bij enkele vermogensrechtelijke rechtshandelingen zoals het aanbod, de volmacht, de bekrachtiging e.a. Ook in het vennootschapsrecht kan ze dus noodzakelijke diensten bewijzen om de oprichting van de eenpersoonsvennootschap te verklaren.

Het dient ook te worden toegegeven dat deze laatste analyse een zekere aantrekkingskracht vertoont om het verloop van de oprichtingshandeling te verklaren wanneer zij het gevolg is van een openbaar beroep op het spaarwezen (artikel 45I W.Venn.). Maar ook in die hypothese kan men het geheel van de verrichtingen niet verklaren zonder de figuur van de overeenkomst of minstens, van de meerzijdige rechtshandeling.

In het (zeldzame) geval van oprichting door openbare inschrijving worden inschrijvers gesolliciteerd nadat de initiatiefnemers de authentieke vennootschapsakte in ontwerp hebben bekend gemaakt. Deze initiatiefnemers, door de wetgever aangeduid als oprichters, sluiten als het ware een oprichtingsovereenkomst onder de opschortende voorwaarde dat (I) voldoende inschrijvers worden gevonden om het vooropgestelde maatschappelijk kapitaal te plaatsen, en (2) dat ter vergadering meer

I6 G. van Solinge en M.P. Nieuwe Weme (m.m.v. R.G.J. Nowak), Mr. C. Asser's Handleiding tot de beoefening van het Nederlands burgerlijk recht. 2. Rechtspersonenrecht. Deel II. De naamloze en besloten vennootschap, Deventer: Kluwer 2009, nr. 37, p. 50-5I.

I7 K. Geens en M. Wyckaert, 'De BVBA herschreven voor één persoon', TRV I988, 5, nr. 2.

I8 Cass. I8 december 1974, Arr.Cass. I975, 46o, JTT 1975, 53, concl. O.M., Pas. I975, 425, RCJB I980, 6I, RW I974-75, I827; Cass. 9 mei I980 (2 arresten), Arr.Cass. 1979-80, II32 en II39, Pas. I980, II2I en II27, JTT 1981, 206, RW I982-83, 3I9, not, T.Aann. I98I, 46, m.nt. M. Senelle; Cass. 3 september I98I, T. Aann. I982, I3I, m.nt. L. Cornelis; J. Van Ryn, 'L'engagement par déclaration unilatérale de volonté en droit commercial', in: Mélanges à l'honneur de Jean Dabin, II, Brussel: Bruylant I965, p. 953-963; P. Van Ommeslaghe, 'Examen de jurisprudence - Obligations', RCJB I975, 629 e.v.; R. Kruithof, 'Overzicht van rechtspraak (I98I-I992) - Verbintenissen', TPR I994, p. 2I9, nr. 34. Anders: F. Dumon, conclusie voor Cass. 28 april I978, Arr.Cass. I978, ror6 e.v.; M. Coipel, 'La théorie de l'engagement par volonté unilatérale', RCJB I980, 65 e.v. Later heeft Coipel de verbindende kracht van de eenzijdige wilsverklaring wel erkend: M. Coipel, 'La théorie de l'engagement par volonté unilatérale et son intérêt particulier en droit des sociétés', in: Mélanges offerts à Pierre van Ommeslaghe, Brussel: Bruylant 2000, p. 2I-5I. 
dan de helft van de bereid gevonden inschrijvers zich niet tegen de oprichting verzetten (artikel 452 W.Venn.).

De kandidaten schrijven zich inderdaad in door een eenzijdige rechtshandeling van toetreding tot de reeds bestaande vennootschapsovereenkomst - zij het dat de opschortende voorwaarde voor haar uitvoering nog niet is vervuld - die hen slechts definitief verbindt indien het volledig kapitaal is geplaatst én niet meer dan de helft van de andere inschrijvers zich verzetten.

Volgens een opvatting die in Frankrijk en in België verdedigers vindt, zou de oprichting van elke, dus ook elke meerhoofdige vennootschap (en ook de toetreding tot een bestaande vennootschap bij kapitaalverhoging) bestaan uit een reeks eenzijdige rechtshandelingen waarbij de deelnemers toetreden tot een instituut. ${ }^{19}$

De zogenoemde institutionele leer is ontleend aan de Franse publieke rechtsleer ${ }^{20}$ en werd aangepast voor de naamloze vennootschap door Gaillard. ${ }^{21}$ Deze theorie poogde te doen inzien dat tal van als geheel op te vatten rechtsbetrekkingen en -situaties die door hun doel zijn geordend, in ruime mate aan de greep van de wilsautonomie zijn onttrokken omdat de wetgever ze op dwingende wijze heeft geregeld. Als types van privaatrechtelijke instituten worden genoemd: het huwelijk, de naamloze vennootschap en de met rechtspersoonlijkheid beklede vereniging. De partijen zouden slechts vrij zijn al dan niet toe te treden tot zulk een instituut waarvan het stelsel van te voren geheel door het objectieve recht is vastgelegd. Anders dan bij de overeenkomst, waarin de partijen vrij hun onderlinge rechtsbetrekkingen regelen, is bij het instituut aan de wil een veel geringere rol toebedeeld. De wilsakt is niets meer dan een toetreding tot ('acte-condition'), de aanvaarding van het gereedliggend geheel van normen en rechtsgevolgen; nevenkwesties alleen zijn vatbaar voor nadere of afwijkende regeling door de partijen.

Bovendien wil de leer van de instelling de nadruk leggen op de doelgerichtheid van het verband. Aan de belangen van de instelling zouden private belangen van de leden ondergeschikt zijn.

I9 Vnl. G. Ripert, Aspects juridiques du capitalisme moderne, Parijs: Pichon et Durand-Auzias I95I, nr. 46, p. Iog e.v.; G. Ripert en R. Roblot, Traitéde droit commercial, Parijs: L.G.D.J. I998, nr. IoI4, p. 79I; J. Van Ryn, Principes, I, nr. 30 I e.v., p. 205, nr. 3I2, 217 en nr. 480, 330; J. Van Ryn, 'L'engagement par déclaration unilatérale de volonté en droit commercial', in: Mélanges à l'honneur de Jean Dabin, II, Brussel: Bruylant I965, p. 953 e.v., inz. p. 957; P.C., noot onder Cass. 27 juni 1975, RPS I975, nr. 5860, 22I.

20 M. Hauriou, Principes de droit public, Parijs: Sirey rgr6; M. Hauriou, Aux sources du droit. Le pouvoir, l'ordre et la liberté, Parijs: Bloud\&Gay I933.

2I E. Gaillard, La société anonyme de demain. La théorie institutionnelle et le fonctionnement de la société anonyme, Parijs: Sirey 1932. 
Deze theorie is het voorwerp geweest van heftige kritiek omdat niet duidelijk is wat zij precies wil aantonen. ${ }^{22}$ Wellicht is zij meer geschikt om bijzondere familiale rechtsfiguren, zoals huwelijk en adoptie, te verklaren dan de naamloze vennootschap. ${ }^{23}$ Kan zij dan nog geschikt zijn om een beter inzicht te verkrijgen in de publieke of beursgenoteerde naamloze vennootschap met multinationale dimensies, dan is zij dat zeker niet voor de veel talrijkere besloten naamloze vennootschappen, laat staan voor de andere vennootschapsvormen. ${ }^{24}$ De leer heeft weliswaar het voordeel gehad het autonoom belang van de instelling te onderlijnen, maar laat in een vennootschap behoorlijk weinig ruimte om de verschillende belangen af te wegen tegen elkaar, het vennootschapsbelang enerzijds, het belang van de leden en dat van de werknemers alsook het algemeen belang anderzijds. ${ }^{25}$ Een aantal vaste wettelijke regels, waarvan de toepassing wegens hun dwingend karakter aan de wil van de partijen is onttrokken, belet niet dat de oprichting een overeenkomst is die contractuele betrekkingen doet ontstaan. Een gelijkaardige toestand kan worden vastgesteld in andere overeenkomsten die duurverhoudingen doen ontstaan, zoals handelshuur, landpacht, arbeidsovereenkomst en dergelijke. Daarmee wil niet zijn gezegd dat de contractuele vrijheid niet fundamenteel groter is in de vennootschappen zonder rechtspersoonlijkheid dan in de vennootschappen met rechtspersoonlijkheid. Maar in verband met deze laatste werd recent te veel aandacht besteed aan het fenomeen van de contractualisatie, ${ }^{26}$ om er zonder meer van uit te gaan dat het om loutere instellingen, of hoogstens om toetredingscontracten zou gaan.

Wanneer men de eigen aard van de oprichtingsovereenkomst en de daaruit in de opgerichte rechtspersoon ontstane betrekkingen in acht neemt, blijkt van de 'institutionele' kritiek niet veel stand te houden. ${ }^{27}$ Het lijkt dus niet erg zinvol de wilsovereenstemming waardoor de meerzijdige rechtshandeling en met name de overeenkomst tot stand komt, te herleiden tot de som van twee of meer eenzijdige rechtshandelingen.

22 Deze kritieken worden duidelijk samengevat door A. François, Vennootschapsbelang in het Belgische vennootschapsrecht: inhoud en grondslagen, Antwerpen: Intersentia 1999 (verder aangehaald als Vennootschapsbelang), nr. 73, p. IO2 e.v.

23 Geen inzicht wordt verkregen uit 'le culte de l'institution et la phobie du contrat' (J. Hamel en G. Lagarde, Traité de droit commercial, Parijs: Dalloz I954, nr. 587, p. 708; vgl. P.J.A. Clavareau, Eenige hulpovereenkomsten: rechtsvergelijkende en dogmatische studie in het bijzonder naar tegenwoordig positief Nederlandsch recht, Leiden: Universitaire Pers leiden I947, p. I55).

24 Vgl. M.J.G.C. Raaijmakers, Rechtspersonen tussen contract en instituut, Deventer: Kluwer 1987, p. 4.

25 J. Ronse, 'Vennootschaps- en verbintenissenrecht', in: Op de grenzen van komend recht. Opstellen aangeboden aan Prof. mr. J.H. Beekhuis, Deventer/Zwolle: Kluwer/W.E.J. Tjeenk Willink I969, p. 207-208 en voetnoot (I).

26 T. Tilquin en V. Simonart, Traité, I, nr. I36, p. IIo e.v.; V. Simonart, 'La contractualisation des sociétés, ou les aménagements contractuels des méchanismes sociétaires', R.P.S. I995, nr. 6668, p. 75 .

27 Vgl. L. Dabin, 'Le droit des sociétés anonymes et la conception contractuelle', Ann. fac. dr. Liège. IV (I959), p. 237 e.v., inz. p. 256; vgl. ook M.J.G.C. Raaijmakers, Joint Ventures: enkele beschouwingen omtrent het rechtskarakter en de concernbetrekkingen van de gemeenschappelijke dochteronderneming (diss. Tilburg), Deventer: Kluwer 1976, p. II2 e.v.; A. Pitlo en M.J.G.C. Raaijmakers, Vennootschaps- en rechtspersonenrecht, Deventer: Gouda Quint 2000, nr. 2.I6, p. II8. 


\section{Dwingend vennootschapsrecht: statuten versus overeenkomst}

\section{I Enkele Vorfragen: de statuten, de overeenkomst en de incorporation by reference}

5. Gemeen recht: statuten en extra-statutaire overeenkomst, soms enkel een kwestie van instrumentum? - Het voorgaande samenvattend kan worden gesteld dat de meeste vennootschappelijke rechtspersonen bij oprichting een contractueel, minstens een meerzijdig moment doormaken. Nadien zijn de volkomen rechtspersonen echter aangewezen op het eigen recht van lidmaatschapsverhoudingen dat grondig verschilt van de duurzame partnership-verhouding in een maatschap. Vragen naar doorwerking van buitenvennootschappelijke contracten tussen leden van een volkomen rechtspersoon vergen een grondig inzicht in het waarom van de verschillen in regeling tussen duurzame lidmaatschapsverhoudingen en duurzame maatschapsverhoudingen (hierna, nr. 7 e.v.).

Vooraf merken we nog op dat doorwerking van het gemeen contractenrecht in het vennootschapsrecht een thema is dat o.i. geen overdreven belang mag hechten aan het instrumentum waarbinnen die doorwerking haar ruimte vindt. De vraag naar de doorwerking betreft met andere woorden zowel de statuten als de extra-statutaire overeenkomst die de vennootschap in een of ander aspect wil beheersen, en uiteraard het gebeurlijk op gespannen voet staan van statuten en extra-statutaire overeenkomst.

Wie het Wetboek van vennootschappen erop naslaat, stelt vast dat de wetgever slordig is omgesprongen met de opsomming van wat in de statuten moet worden opgenomen. ${ }^{28}$

In de volkomen rechtspersonen zijn er vooreerst op straffe van nietigheid voorgeschreven minimale vermeldingen ${ }^{29}$ die de essentiële kenmerken van de betrokken rechtspersoon betreffen: naam, doel, inbreng en kapitaal (artikel 227, $2^{\circ}$ en $454,2^{\circ}$ W.Venn.). Bij gebreke van vermelding van een van deze elementen, is niet alleen de akte, maar ook de vennootschap nietig, behoudens regularisatie.

Daarnaast moet onderscheid worden gemaakt tussen de statutaire vermeldingen die op straffe van niet-tegenwerpelijkheid bij uittreksel moeten worden gepubliceerd in het Belgisch Staatsblad en de andere vermeldingen waarvan het volstaat dat

28 Daarover H. Laga, 'Het reglement van inwendige orde in vennootschappen', TPR I993, 895; J. Pattyn, Aandeelhoudersovereenkomsten. Overdrachtsbeperkingen en stemafspraken in een niet-publieke NV, Brussel: Larcier 2012 (verder aangehaald als Pattyn, Aandeelhoudersovereenkomsten), nr. 20, p. I2-I3; A. Coibion, Les conventions d'actionnaires en pratique. Contraintes juridiques, typologie et application aux opérations de Private Equity, Brussel: Larcier 2010 (verder aangehaald als Coibion, Les conventions d'actionnaires), nr. I527, p. 2 I-26.

29 Buiten de notariële vermeldingen die zijn vereist om van een geldige authentieke akte te kunnen spreken. 
ze samen met de akte worden neergelegd ter griffie (vgl. bijvoorbeeld artikel 69 jo. artikel 453 W.Venn.).

Tot de eerste vermeldingen ${ }^{\circ}$ die worden opgesomd in artikel 69 W.Venn. en die worden gesanctioneerd met niet-tegenwerpelijkheid horen de rechtsvorm; de zetel; de duur; de oprichters en vennoten die hun inbreng nog niet hebben volgestort; het geplaatst, gestort en toegestaan kapitaal; de samenstelling van het vermogen en de conclusies van de bedrijfsrevisor met betrekking tot de inbrengen in natura; het begin en het einde van het boekjaar; de verdeling van de winst (reserves, dividenden, liquidatiesaldo); plaats, dag en uur van de jaarvergadering, alsook voorwaarden van toelating daartoe en van uitoefening van het stemrecht. Benevens deze statutaire vermeldingen moeten ook de aanduiding van bestuurders en commissarissen en hun vertegenwoordigingsmacht worden opgenomen in het uittreksel. Zij horen strikt genomen niet tot de statuten, maar wel tot de oprichtingsakte.

Tot de tweede reeks vermeldingen behoort een veel grotere waslijst, waarvan een gedeelte is opgesomd in artikel 453 W.Venn. voor de NV (artikel 226 voor de BVBA). In dit laatste artikel betreft het merendeel van de vermeldingen de oprichtingsakte in de strikte zin van het woord, en niet de statuten. Toch zijn er interessante bepalingen: de abstracte wijze waarop het bestuur wordt samengesteld, benoemd, gevoerd en vertegenwoordigd; het aantal, de nominale waarde en de soorten van aandelen, en met name in de NV of er ook andere dan aandelen op naam kunnen zijn; de bijzondere voorwaarden die hun overdracht regelen; als er winstbewijzen zijn, hun aantal en hun rechten.

Naast deze statutaire vermeldingen van artikel 453 W.Venn. schrijft het wetboek er ook nog vele andere voor die in hoofdzaak gevallen betreffen waarin de statuten iets 'kunnen' bepalen, in afwijking van een suppletieve wetsbepaling, of 'iets meer' of 'iets minder' kunnen bepalen dan minimaal of maximaal dwingend door de wetgever is vereist. Deze vermeldingen opsommen zou een eindeloze waslijst geven.

Er zijn ook heel wat gevallen waar de wetgever een aanvullende mogelijkheid aanbiedt aan de oprichters en aandeelhouders, en waarvan zij gebruik kunnen maken of niet. Het elektronisch stemrecht en stemmen per brief (artikelen 270 bis en 550 W.Venn.) zijn slechts twee voorbeelden van regelingen waarin de statuten kunnen voorzien. In de NV kunnen de oprichters of de algemene vergadering ook de bevoegdheid om het kapitaal te verhogen binnen zekere grenzen van duur en bedrag aan het bestuur delegeren (toegestaan kapitaal, artikel 603 W.Venn.). Wanneer daarvan gebruik wordt gemaakt, wordt dit een minstens tijdelijke statutaire bepaling.

Vanzelf spreekt dat een reeks door de wetgever aangegeven vermeldingen eenvoudig in de statuten moet zijn opgenomen om de vennootschap rechtsgeldig te maken

30 Sommige daarvan, bijvoorbeeld kapitaal en doel, maken dubbel gebruik uit, want zijn ook op straffe van nietigheid van de akte voorgeschreven. 
(bijvoorbeeld naam) of om enig effect te sorteren (bijvoorbeeld delegatie van emissiebevoegdheid voor toegestaan kapitaal). ${ }^{3 \mathrm{I}}$

In andere gevallen is de keuze van de wetgever voor het instrumentum 'statuten' minder trefzeker, en is de uitwerking van bepaalde gemeenrechtelijk doorwerkende bepalingen zelfs niet noodzakelijk fundamenteel verschillend naargelang ze hun plaats vinden in de statuten of in extra-statutaire bepalingen. Het negotium kan perfect hetzelfde zijn. Zo wordt voor winstverdeling of nog, overdraagbaarheidsbeperkingen, algemeen aanvaard dat, hoewel de wetgever ze in de statuten (artikel 453, $3^{\circ}$ W.Venn.) of zelfs het uittreksel (artikel $69,8^{\circ}$ W.Venn.) wil ingeschreven zien, ze ook geldig extra-statutair kunnen worden overeengekomen. Met betrekking tot overdraagbaarheidsbeperkingen in de NV heeft de wetgever bovendien zelf beide mechanismen, zowel de statutaire als de extra-statutaire, gelijk geregeld (artikel 5 Io W.Venn., zie verder nr. 44 e.v.).

Enkele meer uitgewerkte voorbeelden kunnen helpen aantonen dat statuten en overeenkomsten erg gelijkaardige afspraken met een erg gelijkaardige uitwerking kunnen bevatten.

Traditioneel werd de theorie van de verworven rechten ingeroepen met betrekking tot een aan een welbepaalde aandeelhouder toegekend recht in de statuten, waarmee werd bedoeld dat zodanig recht hem alleen kan worden ontnomen met zijn instemming, zoals elk contractueel recht, ook al werd dat dan in de statuten toegekend..$^{22}$ In zoverre moet deze aandeelhouder worden beschouwd als een derde die een contract heeft gesloten met de vennootschap dat enkel met de wederzijdse toestemming bedoeld in artikel II34 Burgerlijk Wetboek (B.W.) kan worden gewijzigd:33 althans in dit opzicht maakt het weinig uit of het nu een aandeelhouder dan wel een derde is aan wie bijvoorbeeld de statuten een bijzonder voordrachtrecht voor een bestuursmandaat toekennen. ${ }^{34}$ Het in de statuten toegekend contractueel recht verschilt wel in ieder geval daardoor van de extra-statutaire rechten die een vennootschap toekent dat het 'kenbaar' is voor een nieuwe aandeelhouder en derden door enkele lezing van de statuten.

3I K. Geens, 'Draagwijdte van artikel 9, $\mathrm{I}^{\circ}$ Eerste Richtlijn i.v.m. facultatieve bevoegdheden van de raad van bestuur', noot onder HvJ EG I6 december 1997, nr. C-I04/96, Vecht en Plassengebied, TRV I998, 4I.

32 Vgl. Cass. 5 juni I947, Pas. I947, I, (240), 246 : ‘(...) que seuls désormais constituent des droits acquis aux actionnaires et intangibles conformément à l'article II34 du Code Civil, les avantages attribués par le pacte social à certains associés personnellement, et créant, dans le chef de ceuxci, des intérêts propres et spéciaux, à l'exclusion des droits conférés par les statuts à des catégories d'actionnaires.'

33 P. Coppens, L'abus de majorité dans les sociétés anonymes, Gembloux I947, nr. I05, p. I40.

34 Over de aard van dit recht, dat in de Belgische praktijk gemakshalve maar niet helemaal terecht aan een soort van aandelen wordt verbonden, zie Wyckaert, Kapitaal in N.V. en B.V.B.A., nr. 785 , p. 534-535. 
Een ander voorbeeld van relatieve impertinentie van het gebruikte instrumentum is de neerwaartse wijziging van een statutair of extra-statutair vereiste versterkte meerderheid voor een bepaalde beslissing (bijvoorbeeld 90\% voor wijziging van de statutaire bepaling die de samenstelling van de raad van bestuur beheerst). Het is moeilijk denkbaar dat een statutair versterkte meerderheid zou kunnen worden afgezwakt (bijvoorbeeld van 90\% naar $80 \%$ ) door een statutenwijziging bij wettelijke meerderheid die lager zou zijn (per hypothese $75 \%$ ) dan de meerderheid die men wil afzwakken. Dat wijst op een impliciete contractualisering van het instrumentum statuten. Indien een dergelijke versterkte meerderheid door een extra-statutaire overeenkomst zou zijn bepaald, en neerwaarts moet worden aangepast, zou tussen partijen unanimiteit worden gevergd.

Er is weliswaar een verschil naargelang een bepaling (negotium) is opgenomen in het instrumentum 'statuten' of overeenkomst: de statuten zijn de bevoorrechte plaats waar de leden van de vennootschap zich het aanvullend of het suppletief vennootschapsrecht eigen maken. ${ }^{35}$ Zodra dat is gebeurd, makkt dat recht deel uit van hun vennootschappelijke 'overeenkomst', dit zijn de werkingsregels van de vennootschap. In die zin is er geen échte keuze tussen statuten en overeenkomst om van een suppletieve of in één richting dwingende wetsbepaling af te wijken, of om van een wettelijke aanvullingsmogelijkheid gebruik te maken: doet men dat niet in de statuten, dan integreren de statuten stilzwijgend wat volgens de wet rechtens is, en is dat integrerend deel van 'de' statuten.

Zo is bijvoorbeeld van minimaal dwingend recht dat er minstens drie bestuurders moeten zijn. Dus kunnen de statuten bepalen dat er meer moeten zijn. Is dat niet zo, dan is het alsof werd overeengekomen dat er minstens drie moeten zijn. Een afwijkende overeenkomst staat daar haaks op. Bij uitzondering laat de wetgever toe dat er slechts twee bestuurders zijn, met name indien er slechts twee aandeelhouders zijn. Ook in dat geval kunnen de statuten een hoger minimum voorschrijven. Doen ze dat niet, dan staat een afwijkende overeenkomst terzake (die er bijvoorbeeld in voorziet dat er ook dan drie moeten zijn) evenzeer haaks. En men kan verder gaan. Bij een even aantal bestuurders voorziet de wet niet in een doorslaggevende stem voor de voorzitter. Dit is impliciet suppletief, zo blijkt uit het feit dat de wetgever een dergelijke statutaire bepaling uitdrukkelijk buiten werking stelt indien er slechts twee bestuurders zijn.

De superioriteit van de statuten sluit aan bij hun reikwijdte: de statuten zijn bindend voor alle aandeelhouders, voor de organen, voor wie aandeelhouder wordt, en uiteraard voor de vennootschap zelf. De overeenkomst bindt enkel de partijen: het is allerminst evident dat de vennootschap en al haar vennoten partij zijn bij een parallelle overeenkomst (zie ook hierna, nr. 37 en 45). De vennootschap en de 
vennoten die geen partij zijn bij de extra-statutaire overeenkomst moeten zich met andere woorden enkel het bestaan ('extern gevolg') ervan laten tegenwerpen..$^{36}$

De superioriteit van de statuten ten aanzien van extra-statutaire overeenkomsten is apert voor wie direct is betrokken bij de vennootschap. Is zij veel minder duidelijk jegens derden, dan geldt niettemin voor alles het aanvoelen dat derden te goeder trouw ervan mogen uitgaan dat de toestand is geregeld zoals de gepubliceerde statuten aangeven. ${ }^{37}$

Doorgaans houdt men niettemin voor dat de openbaarheid van de statuten enerzijds en de niet-kenbaarheid van de overeenkomst anderzijds geen wezenlijk verschil uitmaken ten aanzien van de tegenwerpelijkheid van de negotia. Ook statuten zouden, ondanks hun neerlegging ter griffie, en hun publicatie bij uittreksel in het Belgisch Staatsblad, in hun obligatoir-intern aspect geen gevolg hebben voor derden.

Inderdaad is de stelling dat de niet-openbaarmaking van de statuten op de correcte wijze tot gevolg heeft dat het bestaan van de desbetreffende bepaling niet tegenwerpelijk is aan de door die openbaarmaking beschermde derden; dit zijn derden die met de vennootschap of met haar organen als zodanig hebben gehandeld en voor wie het feit dat ze kennis hebben van de openbaar te maken akten relevant is of kan zijn voor hun beslissing om op een bepaalde manier met de vennootschap al dan niet te handelen..$^{8}$

Anderzijds zou de correcte openbaarmaking van diezelfde statuten geenszins de tegenwerpelijkheid aan beschermde derden met zich brengen van het obligatoirintern gevolg van de overeenkomst. Niettemin wordt aanvaard dat de correcte publicatie van een statutaire bepaling een vermoeden van kennis teweeg brengt in hoofde van beschermde derden. Dit is het corrolarium van de niet-tegenwerpelijkheid van het niet-gepubliceerde document. Dat dit niet het type kennis is dat volgt uit nemo censetur ignorare legem voor een in het Belgisch Staatsblad gepubliceerde wettekst ligt voor de hand, omdat zo'n vermoeden alle derden treft, en niet enkel de beschermde:

36 Over de draagwijdte van dit beginsel neergelegd in art. II65 B.W. ('res inter alios acta'), zie L. Cornelis, Algemene theorie van de verbintenis, Antwerpen: Intersentia 2000 (verder aangehaald als Algemene theorie van de verbintenis), nr. 28I e.v., p. 345 e.v.; W. Van Gerven en S. Covemaeker, Verbintenissenrecht, Leuven: Acco 200I (verder aangehaald als Verbintenissenrecht), p. I35 e.v. Zie verder ook Coibion, Les conventions d'actionnaires), nr. I3-I4, p. I9-20.

37 H. Laga, 'Het reglement van inwendige orde in vennootschappen', TPR I993, (895), p. 924.

38 Cass. I7 september 1965 , Pas. I966, I, 78, R.W. 1965-66, 989, JT 1966, 91, RPS 1967, nr. 539I 264 ; Kh. Antwerpen 23 juni I969, RHA I969, 47I; J. Ronse, 'Overzicht', T.P.R. I967, 679, nr. 90; J. Ronse, De vennootschapswetgeving 1973, nr. 39-40, p. 20-2I; P. Kileste en C. Bertsch, 'Des effets de la publication de la démission d'un administrateur de société anonyme', JDSC 200I, I44; S. Rutten, 'Art. 76 W.Venn.', in: Artikelsgewijze commentaar, 6, nr. 5; L. Simont, La loi du 6 mars 1973 modifiant la législation relative aux sociétés commerciales, Brussel: Bruylant I975, nr. 25, p. 23-25; T. Tilquin en V. Simonart, Traité, III, nr. 2055, p. 230-23I; M. Van Gils, 'Derdentegenwerpelijkheid van akten van een NV', TRV 2004, p. 707-708. Anders: D. De Marez, 'Een derde is een derde. Over de tegenwerpelijkheid aan derden van akten betreffende rechtspersonen', TRV 2005, 537, nr. Io, die verdedigt dat het onderscheid tussen derden die zich wél en derden die zich niet op de niet-tegenwerpelijkheid kunnen beroepen strijdig is met de bepalingen van de Eerste Richtlijn. 
wie zich niet kan beroepen op een niet-openbaarmaking, kan ook geen nadeel ondervinden van de publicatie. ${ }^{39}$ Zelfs voor beschermde derden zou een echt wettelijk onweerlegbaar vermoeden van kennis de verplichting inhouden steeds de statuten te raadplegen, ongeacht het belang of de urgentie van de transactie. ${ }^{40}$ In elk geval is de schijn tégen de professionele derde die voorwendt onwetend te zijn van het bestaan en de inhoud van die statuten. Ten minste derde-medeplichtigheid aan contractbreuk zal sneller worden aangenomen bij een vennootschapsakte omwille van zijn publicatie (zie ook hierna, nr. 49).

Enkele voorbeelden tonen aan dat de publicatie van de statuten daaraan ook jegens derden in bepaalde gevallen een onmiskenbaar efficiëntie-voordeel geeft boven een gewone overeenkomst. ${ }^{4 \mathrm{I}}$ Voorafgaand merken we op dat, in een aantal gevallen, door het wetboek zelf uitdrukkelijk wordt geweigerd om aan de correcte statutaire bekendmaking het gevolg te koppelen dat de derde wordt geacht ervan op de hoogte te zijn: dat is met name zo voor beperkingen aan bestuurs- en vertegenwoordigingsbevoegdheden (artikel 257 en 522 W.Venn.) en de statutaire doelclausule (artikel 258 en 526 W.Venn.). Hoewel altijd voorzichtig moet worden omgesprongen met a contrario redeneringen, valt er toch iets voor te zeggen dat opname van een bepaling in de statuten haar in de andere gevallen een verhoogde juridische waarde geeft.

Laat ons even uitgaan van de principiële geldigheid van een versterkte meerderheidsbepaling voor statutenwijziging: in plaats van de wettelijke drie vierde meerderheid, zou voor een bepaalde $\mathrm{NV}$ in een meerderheid van vier vijfde worden voorzien. Als deze bepaling in correct openbaar gemaakte statuten staat, zal niemand op het idee komen om een voorstel van statutenwijziging dat met $77 \%$ van de stemmen is aanvaard, als goedgekeurd te beschouwen. Stel nu dat deze vier vijfde-bepaling in een overeenkomst staat, waarbij alle oprichters partij zijn, en waarvan zelfs de vennootschap kennis heeft, en hetzelfde voorstel van statutenwijziging wordt met $77 \%$ aanvaard. Uiteraard zullen derden te goeder trouw gerechtigd zijn ervan uit te gaan dat deze statutenwijziging is verworven, ook al behaalde ze geen vier vijfde meerderheid. Deze conclusie dringt zich des te meer op indien inmiddels vennoten zijn toegetreden die geen oprichter waren, of indien de vennootschap geen kennis heeft van de overeenkomst.

Moet een werkgever, door het loutere feit van de publicatie van de oprichtingsakte van een vennootschap met een concurrerende doelomschrijving waarvan zijn werknemer de belangrijkste aandeelhouder is, ervan op de hoogte zijn dat zijn werknemer

39 S. Rutten, 'Art. 76 W.Venn.', in: Artikelsgewijze commentaar, I2, nr. Io; B. Tilleman, Bestuur van vennootschappen, Brugge: Die Keure 2005 (verder aangehaald als Tilleman, Bestuur), nr. IIo6, p. 70I702.

40 Tilleman, Bestuur, nr. II07, p. 702; S. Rutten, 'Art. 76 W.Venn.', in: Artikelsgewijze commentaar, Io, nr. Io; L. Simont, 'Les règles relatives à la publicité, aux nullités et aux actes accomplis au nom d'une société en formation', in: Les sociétés commerciales, Brussel: Editions Jeune Barreau I985, p. $7 \mathrm{I}$, nr. 9.

4I Zie ook K. Geens, 'L'opposabilité d'une clause statutaire d'agrément ou de préemption', in: Liber Amicorum Commission Droit et Vie des Affaires, Brussel: Bruylant I998, p. 507 e.v. 
hem onrechtmatige concurrentie aandoet en dus een dringende reden voor ontslag creëert die de werkgever slechts beperkte tijd na de ontdekking ervan kan inroepen? Het Hof van Cassatie oordeelde terecht van niet, omdat er door publicatie geen onweerlegbaar vermoeden van kennis ontstaat in hoofde van alle derden. ${ }^{42}$

Delicaat is ook een niet-nageleefde aandelenoverdraagbaarheidsbeperking. Kan men met hetzelfde gezag aan de verwerver te goeder trouw deze niet-naleving door de overdrager tegenwerpen indien de beperking niet in de statuten, maar slechts in een overeenkomst was opgenomen? Dit vraagstuk zal met name het voorwerp uitmaken van paragraaf 3 van dit preadvies. Niet zelden maakt zo'n overdraagbaarheidsbeperking indien ze extra-statutair is, deel uit van een stemovereenkomst, wat in brede zin een verzamelbenaming voor allerlei extra-statutaire afspraken is, maar in enge zin een syndicatair engagement dat ter vergadering van de vennootschap eenieder zal stemmen zoals de meerderheid van de syndicaatsleden in een voorvergadering heeft voorbestemd, ook door wie in de minderheid werd gesteld binnen het syndicaat. De vraag naar de tegenwerpelijkheid van een dergelijke syndicataire afspraak aan de vennootschap en aan de niet-leden van het syndicaat, is natuurlijk de archetypische doorwerkingsvraag, en zal evenzeer in paragraaf 3 de nodige aandacht krijgen (zie hierna, nr. 36 en 44).

Omdat de stemovereenkomst in haar strikte betekenis regelrecht afbreuk doet aan het dwingende meerderheidsbeginsel en de even dwingende regel 'een aandeel, één stem' (zie hierna, nr. 29), kon enkel de wetgever klaarheid scheppen in de geldigheid van dergelijke overeenkomsten. Hij heeft dat ook gedaan, zoals hierna zal blijken (zie hierna, nr. 36 e.v.).

6. Statuten en governance verklaringen: incorporation by reference? - Over de vraag wat er geschiedt indien men in het instrumentum statuten verwijst naar een ander negotium, en of dit negotium door de verwijzing dan ook het statutair karakter aanneemt, is in België weinig of niets geschreven wanneer de statutaire verwijzing een aandeelhoudersovereenkomst zou betreffen. Met verwijzen wordt werkelijk 'verwijzen' bedoeld en in geen geval 'citeren zonder vindplaats', ${ }^{43}$ want in dat geval wordt minstens de indruk gegeven dat het om een échte statutaire bepaling gaat.

Een document waarover wel doctrine bestaat, is het zogenoemde reglement van inwendige orde, dat Laga uitvoerig bestudeerde in haar proefschrift. ${ }^{44}$ Het reglement is een vennootschapsbesluit van het orgaan waarvan het de interne orde regelt,

42 Cass. 5 mei 1976, Arr.Cass. 1976, 994 en Pas. 1976, I, 957: 'uit [art. 76 W.Venn.] volgt niet dat door die bekendmaking een wettelijk vermoeden ontstaat waardoor men zou moeten oordelen dat alle derden op de hoogte zijn van die bekendmaking'.

43 Zie bijvoorbeeld over de vraag wat de regel is indien de statuten letterlijk de (oude) wet zonder verwijzing overnemen, en de wet inmiddels gewijzigd is, K. Geens, 'Principes généraux du régime transitoire de la loi de I8 juillet I99I', in: Le Nouveau droit des sociétés (S.A et S.P.R.L.), Liège: Ed. Scientifique de la Faculté de Droit de Liège I992, p. II-2I.

44 Waarvan een extract werd gepubliceerd in het in voetnoot 34 aangehaalde artikel in TPR I993, p. 895 . 
en deelt dus niet in de bevoorrechte status van de statuten. Overigens kan het reglement alleen afwijken van suppletief of aanvullend recht, in de mate waarin daarvoor een duidelijke grondslag in de statuten te vinden is. Indien de statuten verwijzen in het algemeen naar een reglement van inwendige orde, is dit ruimschoots onvoldoende. Enkel een afwijking die met zoveel woorden is aangekondigd in de statuten als mogelijk te maken in een reglement van inwendige orde houdt steek. Daarmee verwerft de in het reglement voorkomende afwijking niet dezelfde tegenwerpelijkheid aan derden als de statuten. Mogen derden er te goeder trouw van uitgaan dat de toestand is zoals in de statuten beschreven, dan is dat vertrouwen niet zonder meer gerechtvaardigd indien de statuten een expliciete machtiging bevatten om in een reglement van inwendige orde van een bepaalde suppletieve wetsbepaling af te wijken.

In die context is de vergelijking interessant met corporate governance verklaringen waarnaar in statuten wordt verwezen, en met name met wat de bekende Fortis-zaak daarover leert.

In artikel I4a van de statuten van Fortis NV werd bepaald dat 'het bestuur overleg voert en beslist volgens de regels van het Fortis Governance Statement dat van tijd tot tijd wordt aangepast in overeenstemming met de in de statuten van de beide vennootschappen vastgelegde bepalingen.' Dat Governance Statement bepaalt in artikel II.3.2 dat:

'aan de algemene vergadering van aandeelhouders ter besluitvorming moeten worden voorgelegd, onder meer: beslissingen die zo verstrekkend zijn dat ze de identiteit van de Vennootschap veranderen, met inbegrip van, maar niet beperkt tot,

- overdracht aan een derde-partij van een belangrijk deel van Fortis, of één van haar dochtermaatschappijen, zodanig dat Fortis zou stoppen met haar activiteiten in hetzij het verzekeringsbedrijf dan wel het bankbedrijf;

- overname of desinvestering door Fortis, of een dochtermaatschappij, van een belang in het kapitaal van een onderneming, resulterend in een stijging of vermindering van meer dan een derde van het kernvermogen van Fortis zoals bekendgemaakt in de meest recente Jaarrekeningen van Fortis.'

Die bepaling van het Governance Statement is duidelijk opgesteld naar het voorbeeld van artikel 2:Io7a van het Nederlandse Burgerlijk Wetboek dat bepaalt dat:

'Aan de goedkeuring van de algemene vergadering zijn onderworpen de besluiten van het bestuur omtrent een belangrijke verandering van de identiteit of het karakter van de vennootschap of de onderneming, waaronder in ieder geval:

a. overdracht van de onderneming of urijwel de gehele onderneming aan een derde;

b. het aangaan of verbreken van duurzame samenwerking van de vennootschap of een dochtermaatschappij met een andere rechtspersoon of vennootschap dan wel als volledig aansprakelijke vennoten in een commanditaire vennootschap of vennootschap onder firma, indien deze samenwerking of verbreking van ingrijpende betekenis is voor de vennootschap; 
c. het nemen of afstoten van een deelneming in het kapitaal van een vennootschap ter waarde van ten minste een derde van het bedrag van de activa volgens de balans met toelichting of, indien de vennootschap een geconsolideerde balans opstelt, volgens de geconsolideerde balans met toelichting volgens de laatst vastgestelde jaarrekening van de vennootschap, door haar of een dochtermaatschappij.'

Desondanks besliste de raad van bestuur van Fortis alleen, zonder toestemming van de algemene vergadering, om belangrijke delen van Fortis te verkopen, waarop de aandeelhouders naar de rechter gingen. Als verweer riep de raad van bestuur artikel 2:8 lid 2 van het Nederlandse Burgerlijk Wetboek in:

'Een tussen [een rechtspersoon en degenen die krachtens de wet en de statuten bij zijn organisatie zijn betrokken] krachtens wet, gewoonte, statuten, reglementen of besluit geldende regel is niet van toepassing voor zover dit in de gegeven omstandigheden naar maatstaven van redelijkheid en billijkheid onaanvaardbaar zou zijn.'

Dit verweer werd door het Hof van Beroep te Brussel ${ }^{45}$ - zetelend in kort geding verworpen omdat die uitzondering niet terug te vinden was in het Governance Charter. Het hof bevestigt het statutair karakter van het Governance Charter door te overwegen dat 'il ne se conçoit pas que le conseil d'administration puisse infléchir le contenu du chapitre relatif à ce dialogue sans heurter la volonté exprimée par le statement, qu'il est tenu de respecter aux termes des statuts.' De schending van de statuten en van het Governance Charter konden volgens het hof de schorsing van de beslissingen van de raad van bestuur rechtvaardigen.

Die redenering van het Hof van Beroep verschilde grondig van die van de eerste rechter in kort geding. Die laatste stelde immers: ${ }^{46}$

'que le fait qu'il soit fait référence au Statement dans les statuts de Fortis ne saurait avoir pour effet d'incorporer le Statement aux statuts, ni de conférer au Statement le caractère d'une norme statutaire. Qu'il contient au mieux une référence à un acte sous seing privé comportant des règles de bonne gouvernance que le groupe Fortis entend promouvoir dans la gestion de ses affaires; Qu'en ce sens, il est utile de relever que lorsque Fortis entend conférer à une règle particulière la force obligatoire d'une norme statutaire, cette règle semble figurer à la fois dans le Fortis Governance Statement et dans les statuts; (...).'

Daarnaast wees de rechter in kort geding er ook op dat de wettelijke vereisten voor de statutenwijziging niet gelden voor de wijziging van een Governance Charter van de vennootschap. ${ }^{47}$

45 Brussel I2 december 2008, Droit Bancaire et Financier 2008, VI, p. 399-4I9; TRV 2009, 579.

46 KG Kh. Brussel I8 november 2008, Droit Bancaire et Financier 2008, VI, p. 387-395.

47 Op ig februari 2010 heeft het Hof van Cassatie de uitspraak van het Hof van Beroep te Brussel vernietigd en de zaak verwezen naar het Hof van Beroep te Luik (Cass. I9 februari 2oro, JLMB, 20Io, 392). De verbreking van de uitspraak van het Hof van Beroep gebeurde op grond van een motiveringsgebrek en ging niet in op ons vraagstuk. 
De stelling dat corporate governance bepalingen zonder incorporatie in de statuten geen bindende kracht hebben, wordt geschraagd door het argument dat de wijziging van de bepalingen inzake corporate governance niet aan bijzondere regels is onderworpen, wat wel het geval is met statutenwijzigingen. Het Corporate Governance Statement kan inderdaad eenzijdig gewijzigd worden door de raad van bestuur, zelfs wanneer er in de statuten naar wordt verwezen. Dit argument werd zowel door de rechter in kort geding ontwikkeld als door de Raad van State in een advies over de toepasselijkheid van artikel 528 W.Venn. op corporate governance bepalingen.

Een ander argument houdt in dat de verklaring van de onderneming om zich te houden aan een corporate governance code als zodanig geen verbintenis uit eenzijdige wilsverklaring doet ontstaan en sluit zo eerder aan bij de argumentatie in eerste aanleg. ${ }^{48}$ Bekendmakingen inzake het corporate governance beleid hebben immers niet hetzelfde onveranderlijke karakter als de wet of de statuten aangezien de Belgische Code zelf in principe in de mogelijkheid voorziet om het Corporate Governance Charter op elk moment te actualiseren. ${ }^{49}$ Rechtsgevolgen verbinden aan de verklaring inzake corporate governance als ware zij een verbintenis uit eenzijdige wilsuiting zou immers het soft law karakter van de corporate governance volledig uithollen..$^{\circ}$

Mutatis mutandis kunnen gelijkaardige argumenten worden ontwikkeld voor het geval in statuten naar een aandeelhoudersovereenkomst zou worden verwezen. De partijen bij de aandeelhoudersovereenkomst willen deze graag zelf kunnen wijzigen, en de andere partijen, met inbegrip van de vennootschap zelf, durven rekenen op de overeenkomst zoals ze (menen dat ze) luidde ten tijde van de invoeging van de verwijzing in de statuten. Het vermengen door verwijzing van statuten en overeenkomsten ('mélanger les genres') is dus niet aangewezen.

\subsection{De rechtstreekse en onrechtstreekse doorwerking van het gemeen recht in het rechtspersonenrecht: algemeen ${ }^{51}$}

\section{Inleiding - Is er een gemeen vennootschapsrecht? - Op zoek naar de beginselen van de vennootschappen met beperkte aansprakelijkheid - Het vennootschapsrecht}

48 X. Dieux, 'Droit, morale et marché: réflexions sur l'autorégulation en droit des sociétés et en droit financier', in: $X$, La régulation économique dans la vie des affaires: actes du $56^{6}$ séminarie de la commission droit et vie des affaires, Brussel: Bruylant 2007, p. 36; A. Autenne en R. Aydogdu, 'La transparence dans la loi du 6 avril visant à renforcer le gouvernement d'entreprise', Droit Bancaire et financier 2010, p. I72.

49 X. Dieux, 'La responsabilité civile des diregeants', in: X, Actualités en droit des sociétés, Brussel: Bruylant 2006, p. II4-II5.

50 A. Autenne en R. Aydogdu, 'La transparence dans la loi du 6 avril visant à renforcer le gouvernement d'entreprise', Droit Bancaire et financier 20I0, p. I72. Anders liggen de zaken uiteraard voor de regel comply or explain die onder Europese impuls sedert kort in België, althans voor beursgenoteerde ondernemingen, een wettelijk - dat wil zeggen 'hard' - karakter gekregen heeft, zie K. Geens, m.m.v. V. Withofs, 'What if you don't explain why you don't comply?', in: IBJ (red.), Corporate Governance: keurslijf of sleutel tot succes, Brussel/Antwerpen: Bruylant/Kluwer 2010, p. I-43.

$5 \mathrm{I}$ Dit hoofdstuk is gebaseerd op onze eerdere bijdragen 'Les espaces de liberté contractuelle dans le droit des sociétés à responsabilité: entre rapprochement et palliation', in: Les espaces de liberté 
zit geprangd tussen het gemeen burgerlijk recht van 1804 en het bijzonder afwijkend handelsrecht van I807. Deze scheidingslijn valt grotendeels samen met het onderscheid tussen, enerzijds, het recht van de vennootschappen die hun vennoten geen recht geven op de beperkte aansprakelijkheid en, anderzijds, het recht van de vennootschappen met beperkte aansprakelijkheid.

De doorwerking van het privaat recht in het vennootschapsrecht is in de eerste plaats de vraag naar de verhouding tussen het gemeen recht, met inbegrip van het gemeen vennootschapsrecht, en het afwijkend recht van de vennootschappelijke rechtspersonen met beperkte aansprakelijkheid - hierna het rechtspersonenrecht. Prioritair is om te begrijpen in welke mate een systematische en logische interpretatie van het gemeen én afwijkend vennootschapsrecht ruimte laat voor contractuele vrijheid van de partijen. Dat beantwoordt meteen de vraag waarom en in welke mate het gemeen én het afwijkend vennootschapsrecht dwingend zijn. De reden waarom een bepaalde regel dwingend is, kan meestal worden gevonden in de verschillen tussen het gemeen en het afwijkend vennootschapsrecht.

De vraag of voor de benutting van deze contractuele vrijheid de statutaire of de extra-statutaire ruimte moet worden opgezocht, kwam hiervoor (nr. 5) al aan bod.

Historisch is het niet evident om de handelsvennootschappen te beschouwen als een evolutie van de zogenoemde burgerlijke vennootschappen van gemeen recht..$^{2} \mathrm{De}$ Romeinsrechtelijke societas is inderdaad, zonder noemenswaardige potten te breken in de middeleeuwen, door Pothier opnieuw tot leven gewekt. In die zin is zij vanuit het Romeins recht quasi-rechtstreeks in het Burgerlijk Wetboek van I804 terechtgekomen. Van hun kant hebben de handelsvennootschappen in de middeleeuwen een autonome genese en evolutie meegemaakt. Zonder in aanraking te komen met de Romeinsrechtelijke traditie, deed die evolutie hen langs de omweg van de Ordonnance de Commerce (I673) in het Wetboek van Koophandel van I807 belanden.

Hoewel er zich geschiedkundig twee parallelle processen afspeelden, heeft de I 9 -eeuwse wetgever in oud artikel I873 B.W. (I804) en in oud artikel I Boek I, titel IX, W.Kh. (I873) een verbinding gecreëerd: volgens de eerste bepaling vinden de burgerrechtelijke artikelen inzake het vennootschapscontract slechts toepassing op de handelsvennootschappen op die punten die geheel niet strijdig zijn met de wetten en gebruiken op de koophandel; volgens de tweede bepaling vinden op de handelsvennootschappen de overeenkomsten van partijen, de handelsrechtelijke gewoonten en

en droit des affaires, p. I39-I90, in het Nederlands verschenen als 'De ruimte voor contractuele vrijheid bij de vennootschappen met beperkte aansprakelijkheid: tussen toenadering en remederiëring', TRV 2008, p. 527-558 en Algemeen deel, nr. I5-43, p. 38-88. Daarin vindt de lezer ook een volledige inventaris van de wettelijke bepalingen die de BVBA en de NV regelen in het licht van de gemaakte analyse.

52 X. Dieux, 'Les structures élémentaires de la société: "la trahison des images" (à l'ocassion du Ioième anniversaire du Code des sociétés)', in: 10 jaar Wetboek van vennootschappen, Mechelen: Kluwer 20II, p. 5 I e.v. 
het burgerlijk recht toepassing. Daaruit is de gedachte van een gemeen vennootschapsrecht ontstaan dat aansluit bij het contract van burgerlijke vennootschap..$^{53}$

Beide bepalingen werden samengevat in nieuw artikel I8 van Boek II van het Wetboek van vennootschappen (I999). Als eerste bepaling van het boek 'Bepalingen gemeenschappelijk aan alle vennootschappen', schrijft dit artikel voor dat dit boek van toepassing is op alle vennootschappen tenzij daarvan in de volgende boeken wordt afgeweken, en voor de handelsvennootschappen, voor zover de bepalingen van Boek II niet strijdig zijn met de wetten en de gebruiken van de koophandel. Daarmee is niets gezegd over het al dan niet dwingend karakter van de bepalingen van Boek II waarvan voor een volkomen rechtspersoon niet wordt afgeweken, noch over het al dan niet dwingend karakter van een afwijkende bepaling.

Hoe dan ook wordt van die 'gemeenrechtelijke' vennootschapsbepalingen van Boek II niet afgeweken voor de vennootschappen zonder rechtspersoonlijkheid (Boek III), en ternauwernood voor de zogenoemde onvolkomen rechtspersonen (de vennootschappen met rechtspersoonlijkheid maar zonder beperkte aansprakelijkheid, zoals de V.O.F. en de Comm.V (Boek V)).

Het Wetboek van vennootschappen bevat geen boek van gemeenschappelijke bepalingen die enkel gemeen zijn aan alle vennootschappen met volkomen rechtspersoonlijkheid, dat wil zeggen met beperkte aansprakelijkheid voor haar vennoten. Het is ten dele naar die gemeenschappelijke bepalingen dat op zoek wordt gegaan, in ieder geval naar de beginselen die de afwijkingen van het gemeen vennootschapsrecht schragen.

8. Drie types beginselen - Wij pogen de analyse te vereenvoudigen door drie concepten af te spreken. Vooreerst zijn er de beginselen van gemeen recht ${ }^{54}$ waarvan het recht van de vennootschappen met beperkte aansprakelijkheid, dat wil zeggen het rechtspersonenrecht afwijkt (zie Tabel I, kolom I). Dit laatste geschiedt met als leidraad een aantal afwijkende beginselen die het rechtspersonenrecht kenmerken (zie Tabel I, kolom II). Ten slotte zijn er de remediërende mechanismen: zij hebben tot doel deze afwijkingen van het gemeen recht te matigen of te compenseren (zie Tabel I, kolom III). De afwijkende beginselen vormen dus een afwijking van het gemeen recht: indien in tegengestelde richting opnieuw aansluiting of toenadering wordt gezocht bij het gemeen recht, bij wet, statuten of contract, is er sprake van rechtstreekse doorwerking van het gemeen recht in het rechtspersonenrecht. De remediërende mechanismen van hun kant versterken in zekere zin het gemeen recht opnieuw, of zorgen in elk geval zorgen voor een nieuw evenwicht dat in de plaats komt van het

53 Anders: X. Dieux, 'Les structures élémentaires de la société: “la trahison des images” (à l'ocassion du roième anniversaire du Code des sociétés)', in: 10 jaar Wetboek van vennootschappen, Mechelen: Kluwer 20II, p. 68, nr. Io.

54 De bepalingen gemeenschappelijk aan alle vennootschappen, die in Boek II van het Wetboek van vennootschappen zijn opgenomen, maken deel uit van het gemeen recht. 
evenwicht van het gemeen recht. In dit laatste geval spreken we van de onrechtstreekse doorwerking van het gemeen recht in het rechtspersonenrecht.

Tabel I

\begin{tabular}{|c|c|c|}
\hline $\begin{array}{l}\text { I } \\
\text { GEMEEN RECHT }\end{array}$ & $\begin{array}{l}\text { II } \\
\text { RECHTSPERSONENRECHT } \\
\text { (afwijkende beginselen) }\end{array}$ & \begin{tabular}{|l} 
III \\
ONRECHTSTREEKSE DOOR- \\
WERKING GEMEEN RECHT \\
(remediërende beginselen) \\
\end{tabular} \\
\hline $\begin{array}{l}\text { Contractuele band intuitu } \\
\text { personae }\end{array}$ & $\begin{array}{l}\text { Continuïteit van de rechtsper- } \\
\text { soonlijkheid }\end{array}$ & $\begin{array}{l}\text { Overdraagbaarheid } \\
\text { Gedwongen overname }\end{array}$ \\
\hline Eenheid van vermogen & Beperkte aansprakelijkheid & $\begin{array}{l}\text { Maatschappelijk kapitaal } \\
\text { (oprichting, handhaving, } \\
\text { vermindering, oprichtersaan- } \\
\text { sprakelijkheid...) }\end{array}$ \\
\hline $\begin{array}{l}\text { Bindende kracht van de over- } \\
\text { eenkomst }\end{array}$ & Meerderheidsbesluit & Evenredigheid van rechten \\
\hline $\begin{array}{l}\text { Beheersautonomie van de } \\
\text { eigenaar }\end{array}$ & Macht van het bestuursorgaan & $\begin{array}{l}\text { Belangenconflictprocedures } \\
\text { Rekenschapsverplichting } \\
\text { Herroepbaarheid ad nutum } \\
\text { Controle }\end{array}$ \\
\hline
\end{tabular}

De ruimte tussen de gemeenrechtelijke beginselen en de afwijkende beginselen hebben we de 'rechtstreekse doorwerkingszone' gedoopt (zie Tabel 2, kolom Aa). Zo duiden we aan dat het steeds mogelijk is voor aandeelhouders of vennoten, in hun onderlinge verhouding en in die met derden, om het gemeen recht rechtstreeks te laten doorwerken in het rechtspersonenrecht. Hoewel een dergelijke toenadering tot het gemeen recht de partijen verbindt, kan de wetgever ervoor opteren om de doorwerking niet-tegenwerpelijk te verklaren aan derden indien ze hun rechten minder beschermt dan het afwijkend beginsel.

In sommige gevallen heeft de wetgever zelf voor rechtstreekse doorwerking van het gemeen recht in het rechtspersonenrecht gezorgd door middel van specifieke regels (zie Tabel 2, kolom Ab). In dat geval ligt het voor de hand dat de partijen het gemeen recht nog sterker kunnen laten doorwerken dan de wetgever, maar niet minder sterk. Inderdaad, als de wetgever zelf het gemeen recht opnieuw laat doorwerken, duidt hij daarmee aan dat hij op dwingende wijze de belangen wil beschermen van hen die het slachtoffer zouden kunnen worden van de afwijking van het gemeen recht (zie Tabel 2, kolom Ac). 
Tabel 2

\begin{tabular}{|c|c|c|c|c|c|}
\hline \multirow[t]{2}{*}{$\begin{array}{l}\text { I } \\
\text { GEMEEN RECHT }\end{array}$} & \multicolumn{3}{|c|}{$\begin{array}{l}\text { RECHTSTREEKSE } \\
\text { DOORWERKING } \\
\text { GEMEEN RECHT } \\
\text { (toenadering) } \\
\end{array}$} & \multirow{2}{*}{$\begin{array}{l}\text { II } \\
\text { RECHTSPERSONEN- } \\
\text { RECHT } \\
\text { (afwijkende } \\
\text { beginselen) }\end{array}$} & \multirow{2}{*}{$\begin{array}{l}\text { III } \\
\text { ONRECHTSTREEKSE } \\
\text { DOORWERKING } \\
\text { GEMEEN RECHT } \\
\text { (remediërende } \\
\text { mechanismen) }\end{array}$} \\
\hline & $\mathrm{Aa}$ & $\mathrm{Ab}$ & Ac & & \\
\hline $\begin{array}{l}\text { Contractuele banden } \\
\text { intuitu personae }\end{array}$ & \multirow{4}{*}{ 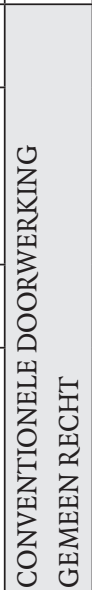 } & \multirow{4}{*}{ 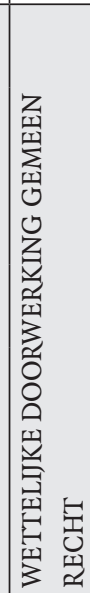 } & \multirow[b]{4}{*}{ 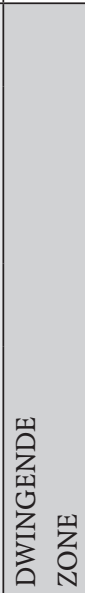 } & $\begin{array}{l}\text { Continuïteit van de } \\
\text { rechtspersoonlijkheid }\end{array}$ & $\begin{array}{l}\text { Overdraagbaarheid } \\
\text { Gedwongen overname }\end{array}$ \\
\hline $\begin{array}{l}\text { Eenheid van } \\
\text { vermogen }\end{array}$ & & & & $\begin{array}{l}\text { Beperkte } \\
\text { aansprakelijkheid }\end{array}$ & $\begin{array}{l}\text { Maatschappelijk kapitaal } \\
\text { (oprichting, handhaving, } \\
\text { vermindering, oprichter- } \\
\text { aansprakelijkheid ...) }\end{array}$ \\
\hline $\begin{array}{l}\text { Bindende kracht van } \\
\text { de overeenkomst }\end{array}$ & & & & $\begin{array}{l}\text { Meerderheids- } \\
\text { beslissingen }\end{array}$ & $\begin{array}{l}\text { Evenredigheid van } \\
\text { rechten }\end{array}$ \\
\hline $\begin{array}{l}\text { Beheersautonomie } \\
\text { van de eigenaar }\end{array}$ & & & & $\begin{array}{l}\text { Macht van het } \\
\text { bestuursorgaan }\end{array}$ & $\begin{array}{l}\text { Belangenconflict- } \\
\text { procedure } \\
\text { Rekenschapsverplichting } \\
\text { Herroepbaarheid ad } \\
\text { nutum } \\
\text { Controle }\end{array}$ \\
\hline
\end{tabular}

De ruimte tussen de afwijkende beginselen van het rechtspersonenrecht en de remediërende mechanismen van de onrechtstreekse doorwerking hebben we de 'aanpassingszone' genoemd (zie Tabel 3, van links naar rechts, kolom B). De remediërende mechanismen zijn uit hun aard dwingender dan de afwijkende beginselen die vooral het leven in de vennootschappelijke rechtspersoon willen vergemakkelijken. Het is precies door te remediëren aan de afwijking, dat deze mechanismen in zekere zin het gemeen recht 'versterken', veelal door een principe ervan uit te werken of te verdiepen en aldus een nieuw evenwicht te scheppen: we spreken daarom van onrechtstreekse doorwerking van het gemeen recht in het rechtspersonenrecht.

De aanpassingen die kunnen worden aangebracht aan de remediërende mechanismen worden dikwijls beperkt door een kleine zone van vrijheid die de wetgever zelf heeft gecreëerd, en dit onder voorwaarde dat de aanpassing door het belang van de vennootschap wordt gerechtvaardigd: zo bijvoorbeeld voor stemovereenkomsten en voor standstill-bepalingen (zie Tabel 3, kolom Ba) (zie ook hierna, nr. 38 en 46). Daarbuiten bestaat de enige wijze om een aanpassing door te voeren in de verzaking. Zij is slechts mogelijk indien het remediërend mechanisme niet aan de openbare orde raakt (zie Tabel 3, kolom Bb). In elk geval kan de verzaking in beginsel slechts geldig geschieden nadat de bescherming van het remediërend mechanisme is ontstaan. 
Tabel 3

\begin{tabular}{|c|c|c|c|c|c|c|c|}
\hline \multirow[t]{2}{*}{$\begin{array}{l}\text { I } \\
\text { GEMEEN } \\
\text { RECHT }\end{array}$} & \multicolumn{3}{|c|}{$\begin{array}{l}\text { RECHTSTREEKSE } \\
\text { DOORWERKING } \\
\text { GEMEEN RECHT } \\
\text { (toenadering) } \\
\end{array}$} & \multirow{2}{*}{$\begin{array}{l}\text { II } \\
\text { RECHTSPER- } \\
\text { SONENRECHT } \\
\text { (afwijkende } \\
\text { beginselen) }\end{array}$} & \multicolumn{2}{|c|}{$\begin{array}{l}\text { AANPAS- } \\
\text { SINGSZONE }\end{array}$} & \multirow{2}{*}{\begin{tabular}{|l} 
III \\
ONRECHT- \\
STREEKSE DOOR- \\
WERKING GEMEEN \\
RECHT \\
(remediërende \\
mechanismen)
\end{tabular}} \\
\hline & Aa & $A b$ & Ac & & $\mathrm{Ba}$ & $\mathrm{Bb}$ & \\
\hline $\begin{array}{l}\text { Contractuele } \\
\text { banden intuitu } \\
\text { personae }\end{array}$ & \multirow{4}{*}{ 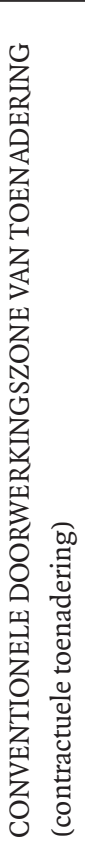 } & \multirow{4}{*}{ 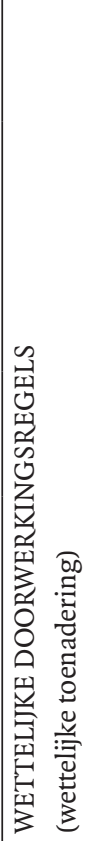 } & \multirow[b]{4}{*}{ 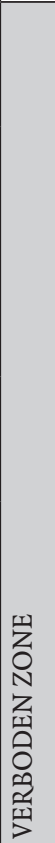 } & $\begin{array}{l}\text { Continuïteit van } \\
\text { de rechtspersoon- } \\
\text { lijkheid }\end{array}$ & \multirow{4}{*}{  } & \multirow[b]{4}{*}{ 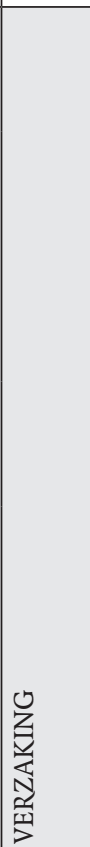 } & $\begin{array}{l}\text { Overdraagbaarheid } \\
\text { Gedwongen over- } \\
\text { name }\end{array}$ \\
\hline $\begin{array}{l}\text { Eenheid van } \\
\text { vermogen }\end{array}$ & & & & $\begin{array}{l}\text { Beperkte aanspra- } \\
\text { kelijkheid }\end{array}$ & & & $\begin{array}{l}\text { Maatschappelijk } \\
\text { kapitaal (oprich- } \\
\text { ting, handhaving, } \\
\text { vermindering, } \\
\text { oprichteraansprake- } \\
\text { lijkheid ...) }\end{array}$ \\
\hline $\begin{array}{l}\text { Bindende } \\
\text { kracht van de } \\
\text { overeenkomst }\end{array}$ & & & & $\begin{array}{l}\text { Meerderheids- } \\
\text { beslissingen }\end{array}$ & & & $\begin{array}{l}\text { Evenredigheid van } \\
\text { rechten }\end{array}$ \\
\hline $\begin{array}{l}\text { Beheersauto- } \\
\text { nomie van de } \\
\text { eigenaar }\end{array}$ & & & & $\begin{array}{l}\text { Macht van het } \\
\text { bestuursorgaan }\end{array}$ & & & \begin{tabular}{|l|} 
Belangenconflict- \\
procedures \\
Rekenschaps- \\
verplichting \\
Herroepbaarheid ad \\
nutum \\
Controle
\end{tabular} \\
\hline
\end{tabular}

\subsection{De vier afwijkende beginselen van het rechtspersonenrecht}

9. De grote beginselen van het gemeen recht en de afwijkende beginselen van het recht van de vennootschappen met beperkte aansprakelijkheid - Het recht van de vennootschappen met beperkte aansprakelijkheid wijkt af van enkele van de meest fundamentele beginselen van gemeen recht.

a. Een eerste fundamenteel principe van gemeen recht is dat het bestaan, de geldigheid en de voortzetting van een 'persoonlijk' (intuitu personae) contract zoals dat van een vennootschap afhankelijk zijn van de 'persoon' van de contracterende partijen. Het recht van de volkomen vennootschappelijke rechtspersonen wijkt daarvan af omdat de rechtspersoon voortduurt niettegenstaande de aantasting door wilsgebreken van de toestemming van één of meer vennoten bij de oprichting, of nog, omdat de rechtspersoon voortduurt ondanks het overlijden of het faillissement van een vennoot (artikelen 229, 3I4, 456 en 6ro W.Venn.).

b. Het tweede fundamenteel beginsel van gemeen recht waarvan het recht van de vennootschappen met volkomen rechtspersoonlijkheid afwijkt, is de eenheid 
van vermogen (artikel 7-8 Hypotheekwet (Hyp.W.)). Krachtens dit beginsel van openbare orde is een schuldenaar verbonden onder al zijn goederen. De beperkte aansprakelijkheid van de vennoten vormt daarop in zekere zin een uitzondering (artikelen 210 en 437 W.Venn).

c. Het derde beginsel van gemeen recht behelst de bindende kracht van overeenkomsten. Dit beginsel betekent dat een overeenkomst niet kan worden gewijzigd dan met de toestemming van alle partijen (artikel II34 B.W.). Het recht van de vennootschappen met volkomen rechtspersoonlijkheid wijkt daarvan af met de meerderheidsregel binnen de algemene vergadering (artikel 63 W.Venn.).

d. Het vierde beginsel van gemeen recht is het recht van de eigenaar om autonoom zijn goederen te beheren (artikel 544 B.W.).

Zijn de eerste twee uitzonderingen goed bekend, dan behoeven de laatste twee enige toelichting. De inbrenger geeft, in ruil voor een aandeel met stemrecht (naar verhouding met de waarde van de inbreng), zijn individuele macht op ten voordele van een collegiaal orgaan, dat wil zeggen de algemene vergadering, waarvan hij lid is, en waarvan de beslissingen zich aan hem opdringen op grond van de meerderheidsregel (derde beginsel). Door middel van deze algemene vergadering verleent hij een beheersmandaat aan een nagenoeg almachtig bestuursorgaan (artikel 257 en 522 W.Venn.) waarvan hij de samenstelling kan beïnvloeden door zijn stemrecht, maar wiens bevoegdheden zijn vastgelegd bij wet (vierde beginsel).

I0. De redenen waarom wordt afgeweken van het gemeen recht - De redenen waarom voor de volkomen rechtspersonen van het gemeen recht wordt afgeweken op deze vier punten, zijn wel bekend.

De eerste bedoeling is zeker de continuïteit van de ondernemingen te bevorderen door hen onafhankelijk te maken van gebeurtenissen die enkel de vennoten treffen, zoals overlijden, faillissement, kennelijk onvermogen, onbekwaamverklaring enzovoort (vgl. artikel 39 W.Venn.).

Op dezelfde wijze is de beperkte aansprakelijkheid een aanmoediging om het ondernemingsrisico te wagen.

Verder vergemakkelijkt het vennootschapsrecht door de meerderheidsregel de besluitvorming in de algemene vergadering.

Ten slotte geeft het vennootschapsrecht aan het bestuursorgaan van de volkomen rechtspersoon de middelen om de vennootschappelijke onderneming op een efficiente manier tot bloei te brengen, in haar eigen belang en dat van al haar 'stakeholders'.

II. De afwijking van het gemeen recht met kennis van zaken, behoudens misbruik - De vennoten of de aandeelhouders en de derden aanvaarden in beginsel de afwijkingen van het gemeen recht. De openbare bekendmaking van de wet en van de vennootschapsstatuten waarborgt afdoende dat deze partijen dit doen met kennis van zaken (zie evenwel ook hiervoor, nr. 5). De toekomstige vennoot of aandeelhouder 
geeft zich bijvoorbeeld rekenschap van de betekenis van het meerderheidsprincipe, of van de verzaking aan bepaalde prerogatieven van een eigenaar. Op dezelfde wijze weet de derde-medecontractant van de vennootschap met beperkte aansprakelijkheid wat hij kan verwachten wanneer hij onderhandelt met een dergelijke vennootschap, of wanneer hij onderhandelt met een vennootschap in oprichting waarvan de promotor zich laat voorstaan op het stelsel van artikel 6o W.Venn., en zich zodoende onttrekt aan zijn verantwoordelijkheid voor eigen handeling.

Gewapend met deze kennis, 'ondergaat' de toekomstige vennoot, aandeelhouder of derde de afwijking van het gemeen recht, of poogt hij op zijn beurt, door onderhandeling, af te wijken van die afwijking (zie hierna, nr.I2). In de twee gevallen oefent deze toekomstige aandeelhouder, vennoot of derde zijn contractuele vrijheid uit, in de eerste hypothese door het vooraf vastgestelde stelsel te aanvaarden waarvan hij kennis had, in het tweede door in onderling overleg met de medecontractant afwijkingen aan te brengen.

De afwijking van het gemeen recht 'ondergaan' betekent in beginsel dat men er niet op wil terugkomen. Er bestaat inderdaad geen wezenlijk verschil tussen de derde die in de uitoefening van zijn contractuele vrijheid aanvaardt om te contracteren met een wederpartij die zich exonereert, en de derde die een overeenkomst sluit met een rechtspersoon met beperkte aansprakelijkheid. In elk geval blijft de uitzondering van misbruik steeds van toepassing: fraus omnia corrumpit. Zo kan de curator trachten de uitbreiding van het faillissement tot de achterman te bekomen om reden van misbruik van rechtspersoonlijkheid, zoals ook de minderheidsaandeelhouder de nietigheid van een vennootschapsbesluit wegens manifest misbruik van meerderheid kan inroepen.

\subsection{De conventionele doorwerking van het gemeen recht in het rechtspersonenrecht}

12. Afwijken van de afwijking van het gemeen recht. Rechtstreekse doorwerkingszone (toenadering) - Omdat de afwijking van het gemeen recht die het rechtspersonenrecht betekent, de essentie zelf van dit laatste recht behelst, is de vraag naar de mate waarin van zijn vier grote afwijkende beginselen kan worden afgeweken erg pertinent. Zoals men zich herinnert, zijn deze principes de continuïteit van de rechtspersoon, de beperkte aansprakelijkheid, de meerderheidsregel en de relatief absolute bevoegdheden van het bestuursorgaan.

Gelet op de bestaansreden van deze vier afwijkende beginselen is het de vennoten en de aandeelhouders, zowel onderling als in hun relatie met derden, toegestaan om van deze beginselen af te wijken in de mate waarin, en precies omdat een dergelijke afwijking het 'afwijkende' vennootschapsrecht opnieuw dichter bij het gemeen recht brengt, dat wil zeggen het gemeen recht laat doorwerken in het rechtspersonenrecht (de zogenoemde toenaderingszone). De afwijkende beginselen van het recht van de volkomen rechtspersonen hebben immers tot doel het vennootschapsleven te vergemakkelijken. Ze beogen niet om op dwingende wijze de belangen te beschermen van de partijen die aan dat 
leven deelnemen. Het is niettemin belangrijk om goed de reden van de doorwerking te vatten en te begrijpen tussen welk beginsel van gemeen recht en welke afwijkende regel zij zich situeert.

\section{Afwijking van beperkte aansprakelijkheid en van eenvoudige meerderheidsregel}

- Hierna volgen enkele voorbeelden van een toenadering tot het gemeen recht van de onbeperkte aansprakelijkheid, respectievelijk de unanimiteit, de eerste strekkende tot voordeel van een derde, de tweede tot voordeel van vennoten of aandeelhouders.

Een afwijking onderhandelen van de beperkte aansprakelijkheid veronderstelt uiteraard een zeker soortelijk gewicht, en blijft dus het voorrecht van bepaalde types van schuldeisers, vennoten en aandeelhouders. Zo kan een institutionele schuldeiser, om het risico dat de beperkte aansprakelijkheid voor hem inhoudt te ontgaan, de persoonlijke borg eisen van een grootaandeelhouder of van de belangrijkste vennoot. Om deontologische redenen engageerden beoefenaars van vrije beroepen die deel uitmaken van een professionele vennootschap zich er in het verleden vaak statutair toe, bij de oprichting of de toetreding tot hun vennootschap, om persoonlijk onbeperkt in te staan voor de schadelijke gevolgen van hun beroepsfouten. Zo men wil, zijn dit twee voorbeelden van doorwerking van privaatrecht in rechtspersonenrecht, het ene in de louter contractuele sfeer, het andere in de statutaire sfeer.

Om de meerderheidsregel te ontgaan kan de oprichter van een vennootschap voor bepaalde beslissingen een goedkeuringspercentage in de statuten doen inschrijven dat de unanimiteitsregel meer benadert. Niets verzet zich er bijvoorbeeld tegen dat in de statuten voor de goedkeuring van de jaarrekening een twee derde meerderheid wordt vereist. Indien een dergelijke bijzondere meerderheid louter contractueel is genegocieerd, zou de jaarrekening die met de gewone meerderheid wordt goedgekeurd, evenwel geldig zijn. Hoogstens bestaat aanleiding tot schadeloosstelling van diegenen die de jaarrekening hebben goedgekeurd jegens de contractanten die dat zonder misbruik niet hebben gedaan (zie hierna, nr. 42).

I4. Mildering van continuïteit door verruimde ontbindingsmogelijkheden - Een oprichter wiens deelname cruciaal is, zou de opname in de statuten kunnen eisen van een clausule op grond waarvan de vrijwillige ontbinding van een vennootschap kan worden beslist met een gewone meerderheid in plaats van met een drie vierde meerderheid. Indien een dergelijke clausule in het licht van de afwijkende regel van de continuïteit wordt bekeken, is ze geldig omdat ze de gemeenrechtelijke regel laat doorwerken of in ieder geval dichter benadert, op grond waarvan elke vennoot eenzijdig de ontbinding van de vennootschap kan uitlokken door eenvoudige opzegging (zie hierna, nr. I9). De ontbinding van gemeen recht, d.i. door de enkele wil van een vennoot, komt inderdaad dichterbij omdat het gemakkelijker is voor één persoon om op meer dan 50\% van het kapitaal in te schrijven dan op $75 \%$. Indien deze clausule daarentegen wordt bekeken tegen de achtergrond van het afwijkende beginsel van de meerderheidsregel, zou ze niet geldig zijn omdat ze zich situeert in de dwingende zone: ze verzacht immers de wettelijke toenaderingsregel die erin 
bestaat een meerderheid van drie vierde te vergen voor elke statutenwijziging (zie hierna, nr. 2I).

Wij kiezen voor de eerste invalshoek, namelijk die van de continuïteit. Kiezen voor de invalshoek van de meerderheid zou betekenen dat de beslissing tot ontbinding in het gemeen recht in beginsel met unanimiteit zou worden genomen. Dit is uiteraard niet het geval, nu het daar precies volstaat dat één enkele vennoot de vennootschap opzegt (artikel 43 W.Venn.). Er is trouwens geen reden om het belang van de continuïteit te overschatten. Het is perfect mogelijk om een vennootschap met beperkte aansprakelijkheid voor een bepaalde duur van bijvoorbeeld twee jaar op te richten. Het gevolg van een dergelijke duurbeperking bestaat erin dat, behoudens misbruik van minderheid, aandeelhouders of vennoten die een blokkeringsminderheid van $25 \%+$ I stem in handen hebben, in staat zijn om elke verlenging te blokkeren.

In datzelfde perspectief, en onder verwijzing naar de alarmbelregel bij een verlies van drie vierde van het kapitaal (artikel 633 W.Venn.) (zie nr. I9), is het zeker niet onlogisch om de geldigheid te verdedigen van een statutaire clausule die de vrijwillige ontbinding onderwerpt aan een percentage van slechts $25 \%$. Ook een dergelijke clausule brengt de vennootschap met volkomen rechtspersoonlijkheid dichter bij het gemeen recht, omdat het voor één persoon gemakkelijker is om $25 \%$ dan $75 \%$ van het kapitaal te onderschrijven.

Opnieuw kan de vraag gesteld worden naar de efficiëntie van een louter contractuele versoepeling van deze meerderheden voor ontbinding. Het spreekt vanzelf dat een ontbinding met minder dan de wettelijk bepaalde meerderheid, ook al is ze dan contractueel voldoende, geen effect kan sorteren. Wel kunnen diegenen die de ontbinding wensen, en contractueel in voldoende getal zijn om zulks te eisen, vanwege de andere partijen bij de overeenkomst, voor zover de stem van deze laatsten toereikend is om de wettelijke meerderheid te bereiken, schadeloosstelling vorderen, misschien zelfs uitvoering in natura (zie hierna, nr. 42).

15. Afwijking van 'de inbreng is de maat van verbintenis' - Zoals men weet, wordt de beperkte aansprakelijkheid dikwijls verwoord als 'de inbreng is de maat van de verbintenis'. Daarmee wordt bedoeld dat een vennoot of aandeelhouder in een vennootschap met beperkte aansprakelijkheid niet kan zijn gehouden tot meer dan tot zijn inbreng. Maar wat indien een clausule een vennoot verplicht om in bepaalde omstandigheden (bijvoorbeeld een bindende derden-beslissing) een nieuwe inbreng te doen in de vennootschap, bovenop de volstorting van zijn oorspronkelijke inbreng? Uiteraard moet een dergelijke verbintenis bepaald of bepaalbaar zijn. Zij beantwoordt niet aan het gemeen vennootschapsrecht, ${ }^{55}$ zodat er van doorwerking geen sprake kan zijn. Inderdaad, behoudens specifieke clausule in die zin, kent

55 De aandeelhouder of vennoot geniet inderdaad verder van de beperkte aansprakelijkheid, maar verhoogt zijn inbreng. Bovendien wordt een dergelijke verbintenis in de praktijk zelden aangegaan in het kader van de relatie met de schuldeisers (die dan zouden kunnen genieten van de toenadering), maar veeleer in de relatie tussen aandeelhouders of vennoten onderling. 
het gemeen recht geen verplichting tot bijkomende inbreng, maar enkel een verplichting voor de vennoten om bij te dragen in de verliezen, de ene tegenover de andere (contributio), in de mate waarin derden-schuldeisers bepaalde vennoten hebben verplicht om de schulden van de vennootschap te betalen (obligatio).

Is het gemakkelijk zo'n verplichting tot bijkomende inbreng te concipiëren in de statuten bij de oprichting van een vennootschap met beperkte aansprakelijkheid ${ }^{5}$ of zelfs later in een contract tussen de belover en de vennootschap en/of andere vennoten of aandeelhouders, dan kan zo'n verplichting tot bijkomende inbreng 'voor het geval dat' niet worden ingevoerd bij een statutenwijziging behoudens unanimiteit (zie hierna, nr. I6). Ook het 'stockdividend'57 moet in het Belgisch recht altijd een optioneel karakter vertonen: de aandeelhouder kan niet worden verplicht om zich te verbinden boven zijn oorspronkelijke inbreng, zelfs indien de middelen die hij daartoe aanwendt afkomstig zijn van een dividend.

I6. Meerderheid vereist voor afwijking van beperkte aansprakelijkheid - Een doorwerking van het gemeen recht inzake onbeperkte aansprakelijkheid vergt de unanieme instemming van elke vennoot of aandeelhouder: hij geeft immers zijn beperkte aansprakelijkheid op. Als deze bepaling niet werd opgenomen bij de oprichting, kan ze later enkel bij unanimiteit worden ingevoegd. Werd ze wel opgenomen bij de oprichting (of nadien bij unanimiteit), dan moeten de 'toekomstige' aandeelhouders of vennoten, dit zijn degenen die later toetreden, zich er wel aan onderwerpen: zij hadden immers de mogelijkheid de statuten te lezen vóór hun toetreding.

Men kan vanzelfsprekend de aandeelhouder of vennoot die heeft gekozen voor de beperkte aansprakelijkheid niet dwingen daaraan te verzaken zonder zijn toestemming. Deze regel wordt overigens bevestigd door artikel 78I W.Venn. dat de unanimiteit vergt voor de omzetting van een vennootschap met beperkte in een vennootschap met onbeperkte aansprakelijkheid..$^{8}$

17. Afwijking van almacht bestuursorgaan - Evenzeer stelt zich de vraag naar de mogelijkheid van een statutaire clausule die de voorafgaande toestemming vergt van de algemene vergadering voor beslissingen die normalerwijze onder de bevoegdheid ressorteren van het bestuursorgaan. Een dergelijke clausule komt dichter bij het gemeen recht omdat ze aan de eigenaar-aandeelhouder een grotere macht geeft

56 Zij die tot de vennootschap toetreden na de oprichting, doen het met kennis van zaken en kunnen zich onthouden indien de statutaire verbintenis die ze zodoende zouden nemen hen niet aanstaat.

57 Dit wil zeggen de mogelijkheid voor de aandeelhouder om zijn dividend onmiddellijk te benutten om een kapitaalverhoging te onderschrijven.

58 Op het eerste gezicht is er maar één uitzondering op die regel, en zij heeft een wettelijke oorsprong: de obligatiehouder kan worden gedwongen door een meerderheid van drie vierde in de algemene vergadering van obligatiehouders om zijn obligaties te converteren in aandelen, en dus om een inbreng in vennootschap te doen (art. 568 W.Venn.). Men moet deze uitzondering relativeren omdat de obligatiehouder erin toestemt bij de onderschrijving van zijn obligatie: nemo censetur ignorare legem. 
over zijn goederen. Zoals men weet, heeft de wetgever de tegenwerpelijkheid aan derden van dergelijke clausules beperkt in de naamloze vennootschap en de besloten vennootschap met beperkte aansprakelijkheid: hun schending wordt gesanctioneerd met louter interne bestuurdersaansprakelijkheid jegens de vennootschap. De vennootschap zelf blijft verbonden door het extern gevolg van de beslissing die het - althans wettelijk bevoegde - bestuursorgaan heeft genomen zonder voorafgaande machtiging van de algemene vergadering (artikel 257 en 522 W.Venn.).

In de reeds uitvoerig besproken Fortis-zaak (zie hiervoor, nr. 6) ${ }^{59}$ kwam de vraag aan de orde of in aanwezigheid van een clausule die de instemming van de algemene vergadering met een belangrijke overdracht van activa voorschreef, een dergelijke overdracht uitwerking kon hebben wanneer de raad van bestuur daartoe besliste zonder die instemming. Traditioneel wordt in België aanvaard dat de overdracht van activa, zelfs van de ganse handelszaak, ressorteert onder de residuaire bevoegdheid van de raad van bestuur, en dat daarvan in de statuten niet op aan derden tegenwerpelijke wijze kan worden afgeweken. In de statuten van de Belgische Fortis Holding NV lagen de zaken specifieker omdat erin werd verwezen naar het binationale Corporate Governance Statement. In dat extra-statutaire Statement dat uitging van de raad van bestuur werd het Nederlandse BW geciteerd op grond waarvan een vennootschap (Fortis Holding NV) geen deelneming in het kapitaal van een andere vennootschap (Fortis Bank) ter waarde van meer dan een derde van het eigen kernvermogen (van Fortis Holding dus) kan overdragen zonder goedkeuring van de algemene vergadering. In dit citaat werd artikel 2:8 $\mathrm{BW}$ weggelaten - waarin met name de derogerende werking van de redelijkheid en de billijkheid wordt gestipuleerd. De rechter in eerste aanleg ging uit van de traditionele Belgische opvatting, namelijk de almacht van de raad van bestuur, en was van oordeel dat de overdracht hoogstens neerkwam op een impliciete wijziging van het Corporate Governance Statement, nu dit een document was dat de raad van bestuur alleen had goedgekeurd. In hoger beroep luidde de beslissing op dit stuk omgekeerd, dat wil zeggen er werd een schending van de statuten aanvaard. Omdat beide beslissingen in kort geding waren, en niet de geldigheid van de overdracht ten gronde betroffen, is hun invloed beperkt. In beroep werd immers mede op grond van andere elementen tot een tijdelijk overdrachtsverbod en de noodzaak van een algemene vergadering beslist. Bovendien werd het arrest van het Hof van Beroep te Brussel vernietigd in cassatie, op andere gronden. Wel heeft de Belgische wetgever op ro juni $2010^{60}$ beslist dat banken tijdens een systeemcrisis door de raad van bestuur alleen, of zelfs door de Staat kunnen worden overgedragen, in beide gevallen in weerwil van een statutaire clausule dat de algemene vergadering moet tussenkomen.

59 Zie ook K. Geens, M. Wyckaert, C. Clottens, F. Parrein, S. De Dier en S. Cools, m.m.v. F. Jenne en A. Steeno, 'Overzicht van rechtspraak - Vennootschapsrecht (2000-20I0)', TPR 2012, 27I, nr. 202.

6o Ingevoegd in artikel $36 / 27$ en $36 / 28$ van de organieke wet op de Nationale Bank van België van 22 februari 1998. 


\subsection{De wettelijke doorwerking van het gemeen recht in het rechtspersonenrecht}

I8. Contractuele of statutaire mogelijkheid om dichter bij het gemeen recht te komen - Verboden zone - Hij die de vrije ruimte tussen het gemeen recht en het afwijkend recht van de vennootschappen met beperkte aansprakelijkheid doorkruist, botst nog op enkele wettelijke regels die zelf een vorm van toenadering tot het gemeen recht behelzen. Het komt voor dat de wetgever zelf een uitzondering invoert op het door hem in eerste instantie geponeerde afwijkende beginsel. Dit beperkt de vrije zone die zich in dat geval enkel uitstrekt in de richting van het gemeen recht, terwijl de ruimte tussen de wettelijke toenaderingsregel en het afwijkende beginsel verboden terrein blijft. De wetgever heeft immers, door zelf het gemeen recht te laten doorwerken, de ruimte voor contractuele vrijheid ingeperkt omdat hij op dwingende wijze de belangen wenst te beschermen van hen die slachtoffer hadden kunnen worden van de afwijking van het gemeen recht.

Men vindt dergelijke wettelijke toenaderingsregels op het niveau van elk van de vier afwijkende wettelijke beginselen.

I9. Alarmbelprocedure - De regel dat bij een vermindering van het netto-actief beneden een vierde van het maatschappelijk kapitaal tot de ontbinding kan worden besloten met een vierde meerderheid is een mooi voorbeeld (artikel 332 en 633 W.Venn.). Zo komen de rechten van de vennoot of aandeelhouder dichter bij het gemeen recht, met name bij het uitgangspunt van artikel 43 W.Venn. op grond waarvan elke vennoot in een vennootschap die voor onbepaalde duur werd aangegaan, haar ontbinding kan teweeg brengen door de louter eenzijdige opzegging. Het principe van de continuïteit wordt door voormeld artikel 633 W.Venn. terzijde gesteld indien een vennoot een vierde van het kapitaal bezit en zijn inbreng geheel dreigt te verliezen. In die logica is het mogelijk om het vereiste stemquotum beneden de drempel van $25 \%$ te leggen, en de ontbinding bij een verlies van drie vierde van het kapitaal in de handen van één vennoot of aandeelhouder te leggen. Anderzijds is het niet aanvaardbaar het in dat geval vereiste stempercentage van $25 \%$ op te trekken (zie hiervoor, nr. I4).

20. Eenhoofdigheid van de NV - Een andere regel die dichter bij het principe van eenheid van vermogen komt, is die op grond waarvan de aandeelhouder die als enige overblijft in een naamloze vennootschap hoofdelijk en onbeperkt aansprakelijk wordt voor alle schulden die werden aangegaan na de eenhoofdigheid, althans indien de vennootschap niet binnen het jaar wordt ontbonden, een tweede aandeelhouder vindt of wordt omgezet in een BVBA (artikel 646 W.Venn.). Het is zeker mogelijk statutair te bepalen dat de enige aandeelhouder al aansprakelijk wordt na zes maanden, of weliswaar pas na een jaar maar voor alle schulden van de vennootschap, zelfs voor degene die werden aangegaan vóór het tot eenhoofdigheid kwam. Maar omgekeerd is het onmogelijk om het ogenblik van hoofdelijke en onbeperkte aansprakelijkheid te verdagen tot na de twaalfmaandenperiode. 
2I. Versterkt aanwezigheids- of meerderheidsquorum bij statutenwijziging - De wettelijke regels van quorum en versterkte meerderheid die gelden bij statutenwijzing behelzen een toenadering tot het gemeen recht (in de zin van de bindende kracht van de contracten). Vanzelfsprekend kunnen de statuten dit percentage van versterkte meerderheid nog verhogen. Maar omgekeerd kunnen de statuten het versterkte meerderheidsvereiste niet verlagen: de doorwerking van het gemeen recht wil inderdaad de (toekomstige) aandeelhouders beter beschermen.

Mogelijk kan een dergelijke statutaire verstrenging van het meerderheidsvereiste voor zekere beslissingen (zoals de wijzigingen van het kapitaal) de facto - in de context van een welbepaalde aandeelhoudersstructuur - een vetorecht aan één aandeelhouder geven. Niettemin is een statutair versterkte meerderheid te verkiezen boven een formeel vetorecht. Een dergelijk vetorecht dreigt immers te worden beschouwd als het contractueel recht van één vennoot of aandeelhouder, en zou hem in dat geval niet kunnen worden ontnomen dan met zijn toestemming, ook indien zijn participatie nadien zou worden verwaterd. Zoals hiervoor (nr. 5) aangeduid, is het moeilijk denkbaar dat een statutair versterkte meerderheid zou kunnen worden afgezwakt (bijvoorbeeld van 90\% naar $80 \%$ ) door een statutenwijziging bij wettelijke meerderheid die lager zou zijn (per hypothese $75 \%$ ) dan de meerderheid die men vermindert. Niettemin blijft een neerwaartse wijziging mogelijk nadat de participatie van de betrokken aandeelhouder is verwaterd tot een niveau beneden het blokkeringsniveau (in het voorbeeld, met 90\% van de stemmen voor een daling naar $80 \%$ ), wat niet het geval zou zijn met een formeel vetorecht.

22. Bijzondere algemene vergadering - Een onrechtstreekse contractuele doorwerking inzake het vierde beginsel is te vinden in de artikelen 556-557 W.Venn. Deze bepalingen herstellen de algemene vergadering in haar autonomie als 'eigenaar' voor zover de vennootschap doelwit wordt van een vijandig openbaar bod, en een van haar kroonjuwelen in het belang van de vennootschap wordt benut in het kader van een beschermingsconstructie. Enkel de algemene vergadering kan, in tempore non suspecto, met gewone meerderheid, een dergelijke maatregel nemen, onder opschortende voorwaarde van het welslagen van zo'n bod (artikel 556 W.Venn.). Een vergelijkbare regel van bevoegdheidstoewijzing is van toepassing wanneer het bod reeds is gelanceerd (artikel 557 W.Venn.).

\subsection{Onrechtstreekse doorwerking van het gemeen recht in het rechtspersonenrecht: door remediëring op zoek naar een nieuw evenwicht}

23. De remediërende mechanismen en hun aanpassingszones. Belang van de vennootschap-Ondanks de fundamentele afwijking van het gemeen recht die het recht van de vennootschappen met beperkte aansprakelijkheid inhoudt, zoekt dit laatste recht ook een nieuw evenwicht dat het gemeenrechtelijke evenwicht vervangt, en wel om mogelijke slachtoffers te beschermen tegen de afwijkingen die de keuze voor een vennootschap met beperkte aansprakelijkheid impliceert. 
Sommige van deze wettelijke regels zoeken opnieuw toenadering tot het gemeen recht, en werden hiervoor reeds aangehaald als voorbeelden van wettelijke rechtstreekse doorwerking van het gemeen recht (zie nr. I8 e.v.). Andere regels komen neer op een uitdieping of een versterking van een gemeenrechtelijk principe dat bijzonder geschikt is om de afwijking van een ander gemeenrechtelijk principe te compenseren of recht te zetten: dan is er sprake van onrechtstreekse doorwerking van dat gemeen recht. Soms kan het remediërend mechanisme niet tot een principe van gemeen recht worden herleid en is het volstrekt oorspronkelijk.

De remediërende regels verschillen dus van de toenaderingsregels door hun techniek. Maar hun strekking is dezelfde, met name de matiging van de radicaliteit van de afwijking afzwakken, en dus een doorwerking van het gemeen recht bekomen. Precies gelet op deze strekking, zijn ze even dwingend als de toenaderingsregels.

De 'aanpassingszones' vormen de ruimte tussen de afwijkende beginselen van het rechtspersonenrecht en de remediërende mechanismen (zie Tabel 3, kolom B). De remediërende mechanismen zijn uit hun aard dwingender dan de afwijkende beginselen die vooral het vennootschappelijk leven willen vergemakkelijken. Door aan de afwijking te remediëren, versterken deze mechanismen in zekere zin het gemeen recht, vaak door een van zijn principes uit te werken of te verdiepen, of eenvoudigweg door dit principe dwingend te maken waar het in het gemeen recht slechts suppletieve werking heeft.

De mogelijke aanpassingen aan de remediërende mechanismen betekenen een kleine zone van vrijheid die de wetgever zelf heeft gecreëerd om wat manoeuvreerruimte te geven aan de contractanten.

De leidraad die moet worden gevolgd bij de uitoefening van deze vrijheid is het belang van de vennootschap: als rechtvaardiging voor een aanpassing van de remedie speelt dit concept een evenwichtsrol. Wat het belang van de vennootschap precies inhoudt, is niet meteen en in algemene termen te definiëren (zie ook artikel ig W.Venn.). Wij omschreven dit begrip al eerder als de vennootschapsrechtelijke vertaling van de goede trouw, dat de grenzen van de subjectieve rechten van de aandeelhouder aangeeft. Zo is bijvoorbeeld het stemrecht een van de belangrijkste van die subjectieve rechten (zie ook hierna, nr. 36). De vrijheid erover te contracteren mag dus niet worden misbruikt, en het belang fungeert dan als correctiemechanisme op die vrijheid..$^{6}$ Hoe het vennootschapsbelang concreet in te vullen is voorwerp geweest van veel discussie, die uiteindelijk tot relatieve stilstand kwam op het snijvlak van de twee belangrijkste opvattingen: geen pure optelsom van de individuele belangen van de huidige aandeelhouders, evenmin de resultante van de belangen van alle stakeholders van de onderneming (aandeelhouders, directie, werknemers, schuldeisers, streek, gemeenschap), maar wel het collectief winstbelang van de aan-

6I O. Caprasse en R. Aydogdu, Les conflits entre actionnaires - prévention et résolution, Brussel: Larcier 20I0, nr. 377-379, p. 2II-2I3; Geens en Wyckaert, Algemeen deel, nr. I42-I43, p. 257-259. 
deelhouders in een continuïteitsperspectief, dat wordt afgewogen tegen de belangen van de andere betrokkenen. ${ }^{62}$ Maar zelfs binnen deze consensus blijft het een relatief open norm, geval per geval in te vullen, waarvan de beoordeling - vaak achteraf-verrassingen kan opleveren. ${ }^{63}$

24. Continuïteit van de rechtspersoonlijkheid: de remediërende mechanismen van de overdraagbaarheid en van de gedwongen overname - De continuïteit die afwijkt van het persoonlijk karakter van het vennootschapscontract wordt op haar beurt geremedieerd door de overdraagbaarheid van de aandelen en in voorkomend geval ook door de gedwongen overname om wettige redenen. Dit tweeledig mechanisme komt overeen met de uitbreiding van twee ideeën die, in hun beginsel, zijn gekend in het gemeen recht: de overdracht van de aandelen, al was het maar door een croupierovereenkomst of een contractuele afwijking op de niet-overdraagbaarheid (artikel 38 W.Venn), en de mogelijkheid om de vennootschap op te zeggen om wettige redenen, zelfs indien deze terugtrekking de gerechtelijke ontbinding van de ganse vennootschap tot gevolg heeft (artikel 45 W.Venn.).

Doordat het continuïteitsbeginsel van de rechtspersoon de mogelijkheid om de vennootschap te ontbinden door eenvoudige opzegging van een vennoot terzijde stelt (artikelen 43, 343 en 645 W.Venn.), verbreekt de continuïteit van de rechtspersoon het evenwicht dat het gemeen recht had geschapen teneinde het principe te handhaven op grond waarvan niemand voor het leven kan zijn gebonden door een overeenkomst voor onbepaalde duur, zelfs als ze intuitu personae werd gesloten. Enerzijds kan de vennootschap die voor onbepaalde duur werd aangegaan zogenaamd op elk moment worden ontbonden ingevolge de loutere opzegging door één enkele vennoot (artikel 43 W.Venn.). Anderzijds zijn de aandelen in een dergelijke vennootschap niet overdraagbaar wat het bestaan van een croupierovereenkomst niet uitsluit. In de maatschap kunnen de partijen dit evenwicht wijzigen voor zover het beginsel dat een persoon niet levenslang kan zijn verbonden wordt geëerbiedigd. Zo kan het maatschapscontract de opzeggingsmogelijkheid uitsluiten en de overdraagbaarheidsmogelijkheden aanzienlijk uitbreiden. ${ }^{64}$ Het is dus geheel logisch dat, in een wettelijk kader waar artikel 43 W.Venn. terzijde is gesteld door de wetgever zelf, precies om de gedepersonaliseerde continuïteit van de vennootschap met beperkte aansprakelijkheid te vergemakkelijken (artikel 343 en 645 W.Venn.), de overdraagbaarheid van de aandelen de bevoorrechte uitgangspoort wordt voor de aandeelhouders of vennoten die de vennootschap willen verlaten. Om redenen van verschillende wettelijke 'specialiteit', is de overdraagbaarheid in de naamloze vennootschap

62 Zie voor deze discussie François, Het vennootschapsbelang, nr. 325, p. 385-389; zie ook W. Van Gerven, 'Bedrijfsbezetting en verkoop in eigen beheer door werknemers van de onderneming', RW I976-77, p. 68; S. Van Crombrugge, Juridische en fiscale eenheidsbehandeling van vennootschapsgroepen, Antwerpen: Kluwer I984, nr. 7I, p. 77; Geens en Wyckaert, Algemeen deel, nr. I44, p. 260262.

63 De wetgever laat de invulling van het concrete vennootschapsbelang over aan de rechter, in functie van de concrete omstandigheden, waardoor aan deze vage norm een essentieel veranderlijke betekenis toekomt: François, Vennootschapsbelang, nr. I32, p. I65.

64 Geens en Wyckaert, Algemeen deel, nr. 88, p. I6r en nr. 434, p. 727. 
in beginsel 'absoluut' en kan ze slechts binnen zekere wettelijke grenzen worden beperkt (artikel 5 Io W.Venn.) (zie daarover hierna nr. 44 e.v.), terwijl ze in de besloten vennootschap met beperkte aansprakelijkheid is onderworpen aan strenge wettelijke beperkingen, maar, in voorkomend geval, de gerechtelijke ontbinding teweeg brengt indien een verkoper zijn koper door de medevennoten niet aanvaard weet zonder dat deze laatsten hem een alternatieve koper tegen een redelijke prijs kunnen voorstellen (artikel 294 en 295 W.Venn.).

De wetgever beseft dat zelfs een absoluut gewaarborgde overdraagbaarheid theorie kan blijven indien er geen liquide markt voor de betrokken aandelen bestaat. Om deze reden heeft hij een remediërende procedure in het leven geroepen in de naamloze en de besloten vennootschappen die geen publiek beroep op het spaarwezen doen of hebben gedaan (artikel 340 en 642 W.Venn.). Op analoge wijze met de gerechtelijke ontbindingsprocedure (artikel 45 W.Venn., hernomen in artikel 343 en 645 W.Venn.), vergt de gedwongen overname de aanwezigheid van wettige redenen, maar anders dan die procedure leidt zij niet tot de ontbinding van de vennootschap. Inderdaad kan de voorzitter van de rechtbank van koophandel zetelend zoals in kort geding, degene die de oorzaak is van de wettige redenen veroordelen tot de overname van de aandelen van degene die zich daarover beklaagt, zonder de continuïteit van de rechtspersoon in het gedrang te brengen. ${ }^{65}$ Het vennootschapsbelang is niet geheel vreemd aan de rechtvaardiging van de gedwongen overname. De wettige redenen hoeven immers geen foutief karakter te vertonen. Als de voorzitter derhalve van oordeel is dat een einde moet worden gesteld aan een situatie van duurzame onenigheid terwijl de kost daarvan niet onoverkomelijk lijkt voor de verweerder, kan hij deze laatste veroordelen tot de overname van de aandelen van de eiser.

Het corollarium van de gedwongen overname of uittreding is de gedwongen overdracht (artikel 334-339 en 636-64I W.Venn.), die neerkomt op de gerechtelijke uitsluiting van een vennoot of aandeelhouder. Zij past in hetzelfde wettelijk kader dat wil remediëren aan de afwezigheid van eenzijdige ontbindingsmogelijkheid, zonder de continuïteit van de vennootschappelijke rechtspersoon en zijn belang uit het oog te verliezen. Het komt bijvoorbeeld aan de voorzitter van de rechtbank van koophandel toe om, wanneer hij wordt gevat door tegenstrijdige eisen van uittreding en uitsluiting, na te gaan of het vennootschapsbelang best is gediend door hetzij de uittreding van de ene vennoot, hetzij diens uitsluiting, hetzij de uittreding of uitsluiting van een andere vennoot. De procedure van uitsluiting kan enkel worden aangespannen

65 In dezelfde zin als de gedwongen overname, remedieert de 'sell out' aan de continuïteit van de beursgenoteerde vennootschap waarvan de aard door het bod aanzienlijk is gewijzigd, maar waaraan de minderheidsaandeelhouder die zijn effecten niet heeft aangeboden geen einde kan stellen: helemaal alleen kan deze laatste de nieuwe controlerende aandeelhouder die 95\% aanhoudt, verplichten om zijn aandelen af te kopen tegen dezelfde voorwaarden als degene die werden geboden bij gelegenheid van het geslaagde openbaar bod (art. 44 van het K.B. van 27 april 2007 op de openbare overnamebiedingen). 
door een vennoot die meer dan 30\% van de aandelen bezit. Eens te meer wordt deze kwantitatieve voorwaarde gerechtvaardigd door het vennootschapsbelang.

25. Aanpassingszone rond de overdraagbaarheid - De vrije overdraagbaarheid van de aandelen remedieert aan de nadelige gevolgen van de continuïteit van de rechtspersoon nu zij de overdracht van de aandelen op gelijk welk ogenblik toelaat, voor zover uiteraard de aandeelhouder een koper vindt. Deze vrije overdraagbaarheid wordt beschouwd als een pijler van het recht van de naamloze vennootschap: $\mathrm{zij}$ maakt deel uit van haar essentie, minstens van haar aard. Niettemin heeft de wetgever zelf een zone van contractuele of statutaire aanpassing gecreëerd rond dit beginsel. Hij staat inderdaad aan de aandeelhouders toe om een intuitu personae element binnen te brengen in de naamloze vennootschapsrelatie. Hij heeft ook de grenzen van die aanpassing strikt aangegeven (artikel 510 W.Venn.) (zie hierna, nr. 44 e.v.).

Het beginsel van de vrije overdraagbaarheid dat enkel de aandeelhouders beschermt, moet trouwens soms op zijn beurt wijken voor dat van de kapitaalbescherming dat o.a. de rechten van derden beschermt. Zo moet de vennootschap derden informeren over het feit dat een aandeelhouder zijn aandeel nog niet heeft volgestort (artikel 506 W.Venn.). Daarnaast blijft de verkoper van een niet-volgestort aandeel, binnen de grenzen van zijn inbreng, gehouden om bij te dragen in de vennootschapsschulden die zijn ontstaan vóór de overdracht (artikel 507 W.Venn.).

In de BVBA zijn de zaken minder duidelijk. Om reden van haar specialiteit is de overdraagbaarheid van de aandelen onderworpen aan strenge beperkingen (artikel 249 e.v. W.Venn.) die beogen te vermijden dat de vennoten zouden worden geconfronteerd met een vennoot die ze niet wensen. De overdraagbaarheid moet dus op dwingende wijze wijken voor het besloten karakter van deze vennootschapsvorm. De statuten kunnen deze wettelijke begrenzingen derhalve strenger maken, maar ze kunnen ze niet verzachten. De wetgever was zich niettemin bewust van het risico dat een vennoot op die wijze de gevangene zou worden van zijn aandelen. Daarom is hij, zoals hiervoor aangegeven (zie nr. 24), verder gegaan in de remediëring omdat, ultiem, de BVBA door de rechter kan worden ontbonden indien de partijen er niet in slagen de horde van de kandidaat-vennoot te nemen. Anders gezegd, de ultissimum remedium bestaat erin de continuïteit van de rechtspersoon op te offeren.

26. Beperkte aansprakelijkheid: de remedie van het maatschappelijk kapitaal, zijn vorming, zijn handhaving en zijn vermindering - Het afwijkend beginsel van de beperkte aansprakelijkheid wordt geremedieerd door het mechanisme van het maatschappelijk kapitaal in zijn verschillende aspecten: vorming ${ }^{66}$ handhaving ${ }^{67}$ en vermindering. ${ }^{68}$ Het principe van gemeen recht dat wordt versterkt en uitgediept, en

66 Zoals bijvoorbeeld de controle van de inbreng in natura, de storting van de inbreng in geld op een geblokkeerde bankrekening, de onvoorwaardelijkheid van de inbreng, enzovoort.

67 In de eerste plaats de art. 320 en 6I4 W.Venn.

68 Art. 3 I7 en $6 I_{3}$ W.Venn. 
dat dus onrechtstreeks doorwerkt, is het verbod zich vrijwillig insolvabel te maken (artikel $\mathrm{I}_{67}$ B.W.). Dit verbod is uiteraard in zijn algemeenheid ook van toepassing op de naamloze vennootschap, maar wordt verbreed en verdiept door technieken waarvan de finaliteit erin bestaat om de daling van het vennootschappelijk vermogen beneden zijn kapitaalcijfer te vermijden, nog los van de intentie om derden te benadelen.

De vorming van het kapitaal wordt gesanctioneerd door de aansprakelijkheid van de oprichters. Zij wil vooral de ongelukkige combinatie vermijden van continuïteit van de rechtspersoon enerzijds en van beperkte aansprakelijkheid anderzijds, zoals die zich voordoet indien wilsgebreken de oprichtingshandeling aantasten. In een maatschap, en ook in de vennootschappen met onbeperkte aansprakelijkheid, wordt de nietigheid van een inbreng ten gevolge van een wilsgebrek bij een vennoot gecompenseerd door de onbeperkte aansprakelijkheid van alle andere vennoten, en loopt ze normalerwijze uit op de nietigheid van de vennootschap. Dit is het regime van de personenvennootschappen (hiervoor, nr. 9). De vennootschap met beperkte aansprakelijkheid is een kapitaalvennootschap, en dus is er altijd continuïteit van de rechtspersoon, terwijl de inbreng van de betrokken vennoot of aandeelhouder nietig wordt zodat hij deze ten laste van de vennootschap kan terugnemen. Het uiteindelijke resultaat voor de derden is een verlies van kapitaal en dus van onderpand. Aan deze lacune wil de hoofdelijke aansprakelijkheid van de oprichters voor de nietige inbreng remediëren (artikelen 229, 314, 456 en 6Io W.Venn.). ${ }^{69}$

27. Aanpassingszone rond het maatschappelijk kapitaal. Oprichtersaansprakelijkheid - Als onderdeel van de maatregelen die de vorming van het maatschappelijk kapitaal beschermen, verzacht de oprichtersaansprakelijkheid het beginsel van de beperkte aansprakelijkheid. Alleen in de naamloze vennootschap heeft de wetgever de aanpassingszone rond deze aansprakelijkheid afgegrensd, en heeft hij op dwingende wijze aangeduid in welke mate een oprichter eraan kan ontsnappen. Een oprichter die ten minste een derde van het kapitaal inbrengt, kan zijn medeoprichters voor oprichtersaansprakelijkheid vrijwaren, met extern gevolg, op voorwaarde dat deze laatsten uitsluitend geld inbrengen en geen enkel bijzonder voordeel ontvangen (artikel 450 lid 2 W.Venn.).

Anderzijds belet niets om in de statuten de oprichtersaansprakelijkheid aan strengere eisen te laten voldoen (vgl. hiervoor, nr. I3). Bij oprichting van de vennootschap door middel van inschrijvingen (artikel 45I W.Venn., zeer zeldzaam in de praktijk), dragen evenzeer enkel de promotoren die verschijnen bij het verlijden van de voorlopige akte de oprichtersaansprakelijkheid. Ze kunnen daar niet aan ontsnappen,

69 In bepaalde gevallen is de aansprakelijkheid beperkt tot een welbepaalde schade; in andere gevallen, bijvoorbeeld in het geval van een ontoereikend kapitaal dat heeft bijgedragen tot het faillissement binnen de drie jaar na de oprichting, kan de rechter de aansprakelijkheid appreciëren en uitbreiden tot een geheel of een gedeelte van het netto-passief. 
maar niets belet om de oprichtersaansprakelijkheid uit te breiden tot de latere inschrijvers.

28. Meerderheid: remediërend mechanisme van de evenredigheid - Verfijnde mechanismen van evenredigheid trachten de (on-)evenwichtsproblemen te compenseren die het afwijkend meerderheidsbeginsel zou kunnen veroorzaken. Het vennootschappelijk evenredigheidsprincipe verdiept en verbreedt het suppletief beginsel van gemeen recht op grond waarvan de winsten van een vennootschap naar verhouding met de inbrengen worden verdeeld (artikel 30 W.Venn.). Het recht van de vennootschappen met volkomen rechtspersoonlijkheid makt dit evenredigheidsprincipe grotendeels dwingend en breidt het uit tot alle vennootschappelijke en patrimoniale rechten die zijn verbonden met een aandeel: het stemrecht, $7^{\circ}$ het dividendrecht ${ }^{71}$ en het voorkeurrecht (artikel 309 en 592 W.Venn.). Inzake het voorkeurrecht is het evenredigheidsbeginsel enkel van toepassing op inbrengen in geld..$^{2}$

29. Aanpassingszone rond het remediërend mechanisme van het evenredig stemrecht. Winstbewijzen en aandelen zonder stemrecht. Stemovereenkomst - Het recht van de vennoot of de aandeelhouder om zich uit te drukken met zijn stemrecht, is sedert 1934 absoluut: één aandeel geeft recht op één stem (artikel 275 en 54I W.Venn.). In de huidige stand van het Belgisch recht bestaan er drie afwijkende pistes ten aanzien van dit beginsel: de uitgifte van aandelen zonder stemrecht (artikel 240 en 480 W.Venn.); alleen in de naamloze vennootschap, de uitgifte van winstbewijzen die, ondanks een inbreng van geld of goederen, niet met het stemrecht moeten zijn bekleed (artikel 542 W.Venn.); ten slotte een statutaire beperking van het aantal stemmen waarover een vennoot of aandeelhouder kan beschikken op de algemene vergadering (artikel 277 en 544 W.Venn.).

Voor de aandelen zonder stemrecht heeft de wetgever het toegestaan kader op een zeer strikte manier uitgetekend. Het is opmerkelijk dat het verlies van evenredigheid vrijwel geheel wordt gecompenseerd door patrimoniale voorrechten. Wanneer deze voorrechten niet worden gehonoreerd, leidt dat tot een herstel van het stemrecht (artikel 24I en 48I W.Venn.). In de praktijk heeft precies dit verlies van prerogatieven en hun sanctie tot gevolg dat deze aanpassingszone volstrekt wordt onderbenut. Er worden weinig of geen aandelen zonder stemrecht uitgegeven.

70 Met dien verstande dat, kennelijk vanuit een loutere bekommernis tot mathematische vereenvoudiging, de wetgever beslist heeft de fracties van stemmen te negeren in de naamloze vennootschap (art. 54I W.Venn.). Andere oplossingen waren nochtans mogelijk, zoals de regel in de BVBA die de creatie van kapitaalsaandelen met ongelijke waarde verbiedt, of nog, het Nederlandse systeem, dat enkel die fractie negeert die rest na optelling van alle fracties ten aanzien van eenzelfde aandeelhouder.

7I Als men zich beperkt tot één soort aandelen.

72 Men kan zich de vraag stellen naar de opportuniteit van ditzelfde beginsel bij inbreng in natura, zoals dit bijvoorbeeld het geval is in het Duitse en het Deense recht, daargelaten dat de afwijkingen kunnen worden versoepeld. 
In datzelfde perspectief is de grote vrijheid die de wet laat aan de naamloze vennootschap om winstbewijzen uit te geven zonder stemrecht, zonder dat dit op patrimoniaal vlak wordt gecompenseerd, enkel een bevestiging van het vermoeden dat de wetgever niet de tijd en de moeite heeft genomen om een logisch wettelijk kader uit te werken voor een aandelenklasse 'van tweede categorie' (zie ook hierna, nr. 47).

In beide gevallen staat de aanpassingszone niet toe om te raken aan de respectieve rechten van de titularissen van aandelen zonder stemrecht of winstbewijzen. Op het ogenblik dat daarvan sprake is, worden zij immers op dwingende wijze hersteld in hun proportioneel stemrecht (artikel 56o W.Venn.).

De statutaire beperking van het stemrecht wordt ook beperkt door het beginsel van de evenredigheid. De beperking is enkel geldig indien ze zich opdringt aan elke vennoot of aandeelhouder, welke ook de effecten zijn waarmee hij deelneemt aan de stemming. In de praktijk moet dit beginsel echter worden gerelativeerd (zie hierna, nr. 38).

Overigens moet ook de stemovereenkomst, om geldig te zijn, worden gerechtvaardigd door het belang van de vennootschap, zoals veel aanpassingen aan de remediërende mechanismen (artikel 28I en 55I W.Venn.). De stemovereenkomst kan tot op zekere hoogte zo'n aanpassing inhouden: inderdaad staat de overeenkomst toe dat bepaalde vennoten of aandeelhouders anticipatief verzaken aan de persoonlijke uitoefening van hun stemrecht, na te hebben deelgenomen aan een predeliberatie, voor zover de verzaking is beperkt in de tijd, zij de regels van het vennootschapsrecht eerbiedigt en zij op elk moment gerechtvaardigd blijft door het belang van de vennootschap (zie hierna, nr. 38).

30. Aanpassingszone rond het remediërend mechanisme van het evenredig dividendrecht - Soorten van effecten - Kapitaalvermindering en aanpassing - De Boeken VI en VIII van het Wetboek van vennootschappen in verband met de naamloze vennootschap en de besloten vennootschap met beperkte aansprakelijkheid bevatten geen specifieke regel in verband met de verdeling van de winsten en de verliezen tussen de vennoten of de aandeelhouders. Derhalve is de suppletieve regel van gemeen recht van toepassing waardoor het recht op de winst wordt verdeeld naar verhouding met de inbreng (artikel 30 W.Venn.).

Deze regel is dwingend voor de BVBA waar geen enkele ruimte voor aanpassing is gelaten, daargelaten het uitzonderlijke geval waarin preferentiële aandelen zonder stemrecht zouden zijn gecreëerd (zie hiervoor, nr. 29).

Voor de naamloze vennootschap is de wetgever soepeler geweest. Het is inderdaad mogelijk verschillende soorten van aandelen te creëren, en aldus de evenredigheid 
tussen de inbreng en het dividendrecht te verbreken.73 De toegestane graad van onevenredigheid is redelijk groot, voor zover binnen elke soort van effecten de proportionaliteit wordt gerespecteerd. De enige intercategoriële begrenzing die wordt gesteld aan de 'disproportie' tussen de kapitaalwaarde enerzijds en het aandeel in winst of verlies anderzijds, is het leonijns verbod (artikel 32 W.Venn.). ${ }^{74}$

Wanneer de verhouding tussen de verschillende soorten van effecten ter discussie staat, en één soort wordt vervangen door een andere, voorziet de wet in een zeer oorspronkelijk remediërend mechanisme (zie hiervoor, nr. 29). Een dergelijke wijziging van de onderlinge verhouding tussen de rechten is slechts toegelaten indien in elke soort aandelen die door de wijziging van rechten wordt geraakt aan de voorwaarden van quorum en versterkte meerderheid die voor een statutenwijziging is vereist is voldaan (artikel 560 W.Venn.).75 Ingevolge zijn bestaansreden kan dit percentage worden verhoogd noch verlaagd door de statuten. Bovendien kan dit mechanisme niet leiden tot de afschaffing van een soort zonder vervanging van deze laatste door een andere, of zonder de toestemming van alle leden van die soort omdat elke andere oplossing zou neerkomen op een uitsluiting. ${ }^{76}$

Dezelfde regel van evenredigheid is van toepassing bij kapitaalvermindering (formeel of reëel). De gelijke behandeling die de wet voorschrijft (artikel 3I6 en 6I2 W.Venn.) impliceert, tenminste in al haar gestrengheid, dat alle vennoten of aandeelhouders op evenredige wijze de gevolgen van de vermindering ondergaan. De praktijk en de recente doctrine houden evenwel voor dat de gelijke behandeling ook is gewaarborgd indien de loutere mogelijkheid (in tegenstelling tot de verplichting) om op evenredige wijze deel te nemen aan de kapitaalvermindering wordt geboden aan alle aandeelhouders of vennoten.

Deze vertaling van het evenredigheidsbeginsel door de loutere mogelijkheid van evenredige deelname bestaat evenzeer bij de inkoop van eigen aandelen (artikel 322, $4^{\circ}$ en 620 S I, $5^{\circ}$ W.Venn.). De mogelijkheid die aan alle aandeelhouders of vennoten wordt gelaten om hun aandelen tegen dezelfde voorwaarden aan te bieden, volstaat om van gelijke behandeling te spreken (door middel van een proportionele reductie van de aangeboden aandelen indien meer aandelen worden aangeboden dan

73 Hoewel de wetgever, toen hij het wettelijk begrip van de soorten van aandelen invoerde, uiteraard beoogde een disproportionaliteit mogelijk te maken tussen de vermogensrechten van de aandelen en hun kapitaalwaarde (met name wat betreft de winst- en verliesdeling), heeft de praktijk deze intentie gedenatureerd door het begrip uit te breiden naar de vennootschappelijke rechten, zoals het vetorecht, de overdraagbaarheid van aandelen en het recht van (on-)evenredige vertegenwoordiging in de raad van bestuur.

74 In afwijking van het gemeen recht, wil het principe van continuïteit dat de leonijnse clausule in een vennootschap met beperkte aansprakelijkheid voor niet-geschreven wordt gehouden, in plaats van de nietigheid van de vennootschap te veroorzaken (art. 228 en 455 W.Venn.).

75 De invoering van een nieuwe soort dient zich dan aan als een 'eenvoudige' statutenwijziging voor de enige voordien bestaande soort: in zo'n geval ondergaan alle bestaande aandelen op evenredige manier de impact van de bijzondere regels van de nieuwe soort.

76 Men moet dus in ieder geval het unanieme akkoord verkrijgen van alle titularissen van aandelen waarvan de afschaffing wordt voorgesteld. 
de vennootschap mag of wil kopen). In een genoteerde vennootschap moeten de voorwaarden zelfs niet identiek zijn voor alle aandeelhouders: het volstaat dat de prijzen waartegen de aandeelhouders hun effecten aanbieden niet hoger zijn dan de marktprijs (artikel 208 K.B. W.Venn.). Uiteraard mag de vennootschap geen aandeelhouders bevoordelen ten nadele van anderen door het moment van aankoop 'oordeelkundig' te kiezen.

3I. Aanpassingszone rond het remediërend mechanisme van het evenredig voorkeurrecht - De evenredigheid is ook de dwingende regel die de vennoot of de aandeelhouder toestaat om zijn relatief aandeel te behouden bij een kapitaalverhoging in geld. Daarom genieten alle vennoten of aandeelhouders een aan de kapitaalvertegenwoordigende waarde van hun aandelen evenredig voorkeurrecht.

In de naamloze vennootschap bestaat een beperkte manoeuvreerruimte die men niet terugvindt bij de besloten vennootschap. Artikel 596 e.v. W.Venn. staat inderdaad aan de algemene vergadering van een naamloze vennootschap toe om het voorkeurrecht op te heffen of het te beperken bij gekwalificeerde meerderheid. De algemene vergadering neemt deze beslissing met kennis van zaken (vandaar de bijzondere verslagen die worden gevergd van de raad van bestuur en de commissaris) in het belang van de vennootschap. Indien het risico op ongelijke behandeling toeneemt, omdat een uitsluiting of beperking van het voorkeurrecht wordt beoogd in het belang van één of meer bepaalde personen, moeten de bijzondere verslagen gedetailleerder zijn en is er een patrimoniale bescherming onder de vorm van een minimumprijs waartegen de kapitaalverhoging moet worden geplaatst (artikel 598 W.Venn.). ${ }^{77}$

32. Bevoegdheid van het bestuursorgaan: remediërend mechanisme van de jaarrekenschapsverplichting en van de controle - Het mechanisme dat remedieert aan de ruime bevoegdheden van het bestuursorgaan bestaat in de versterking van de verplichting om rekenschap te geven die in het gemeen recht wordt opgelegd aan de lasthebber door artikel 1993 B.W. en die wordt gesanctioneerd door zijn herroepbaarheid ad nutum in artikel 2004 B.W.

Bovendien moeten de quasi-onbeperkte bevoegdheden van het bestuursorgaan worden uitgeoefend in het strikte belang van de vennootschap, wat aan elk van zijn leden verbiedt om rekening te houden met het eigen belang en meteen gebiedt om in

77 Indien niet de algemene vergadering over de kapitaalverhoging beslist, maar de raad van bestuur in het kader van het toegestaan kapitaal, is de wet nog voorzichtiger, door specifieke machtigingen te eisen voor de opheffing of de beperking van het voorkeurrecht (art. 605 W.Venn.), en door zonder meer bepaalde verrichtingen van opheffing of beperking van het voorkeurrecht te verbieden aan de raad van bestuur in het kader van het toegestaan kapitaal (art. 606 en 607 W.Venn.). 
voorkomend geval een strenge procedure van belangenconflict te respecteren (artikel 258-26I en 523 W.Venn.). ${ }^{78}$

In het recht van de vennootschappen met volkomen rechtspersoonlijkheid moet de rekenschapsverplichting worden nagekomen ten aanzien van de algemene vergadering, wat niet het geval is in het gemeen recht dat in beginsel dit orgaan niet kent.

De rekenschapsverplichting moet worden nagekomen overeenkomstig een hele reeks dwingende regels die het jaarrekeningenrecht vormen. Het bestuursorgaan doet verslag aan de algemene vergadering over de activiteiten van het voorbije jaar (artikel 94 e.v. W.Venn.), stelt ('arrête') de rekeningen vast (artikel 92 e.v. W.Venn.) en vraagt de goedkeuring ervan door de algemene vergadering (artikel 284 en 554 W.Venn.). Met het oog op deze goedkeuring kunnen de aandeelhouders of vennoten de stukken vooraf raadplegen (artikel 283 en 553 W.Venn.) en meer in het algemeen beschikken zij over een individueel controlerecht in de 'kleine' vennootschappen met beperkte aansprakelijkheid (artikel I65-I67 W.Venn.), terwijl zij zich in de grote vennootschappen moeten laten bijstaan door een commissaris (artikel I30 e.v. W.Venn.). Deze laatste komt niet alleen tussen in het belang van de aandeelhouders of de vennoten, maar ook in het belang van werknemers en derden, en zodoende van het ganse maatschappelijk verkeer. In zijn verslag aan de vergadering geeft hij een verklaring over het getrouw beeld van de rekeningen (artikel I44 W.Venn.).

Door een afzonderlijke stemming stelt de algemene vergadering de winstverdeling vast en geeft zij in voorkomend geval kwijting aan de leden van het bestuursorgaan (artikel 284 en 554 lid 2 W.Venn.). Door de kwijting te weigeren aan één of meer leden van het bestuursorgaan, behoudt de vergadering zich het recht voor om een actio mandati tegen hen in te stellen (artikel 289 en 56r W.Venn.).

33. Macht van het bestuursorgaan: remediërend mechanisme van de herroepbaarheid ad nutum en aanpassing - De algemene vergadering benoemt $\mathrm{t}^{79}$ en herroept de leden van het bestuursorgaan (artikel 256 en 518 \$ 2 W.Venn.). In het recht van de naamloze vennootschappen is de maximale termijn van het bestuursmandaat zes jaar, en zelfs binnen die termijn kan de bestuurder ad nutum worden herroepen. Eens te meer gaat het over een versteviging van het gemeen recht waarin de herroepbaarheid ad nutum enkel suppletief is. In de naamloze vennootschap daarentegen is zij volgens het Hof van Cassatie van openbare orde en laat ze dus geen enkele ruimte voor aanpassing (artikel 518 § 3 W.Venn.) (zie ook hierna, nr. 34 en 38).

Door haar verschillende specialiteit kent de BVBA de herroepbaarheid ad nutum, maar er wordt, naar het voorbeeld van het gemeen vennootschapsrecht, een

\footnotetext{
78 Ook art. 524 W.Venn. kan worden vermeld, maar deze regel lost veeleer het belangenconflict van de controlerende aandeelhouder in de beursgenoteerde naamloze vennootschap op, en ressorteert dus eerder onder de mechanismen die remediëren aan de meerderheidsregel. Dit artikel is een goed voorbeeld van een aan het vennootschapsrecht eigen remedie (hiervoor nr. 23).

79 Behoudens statutaire of conventionele clausule van proportionele vertegenwoordiging.
} 
aanpassingszone gelaten. Het is inderdaad mogelijk om een - behoudens wettige redenen - onherroepelijke statutaire zaakvoerder te benoemen (artikel 256 W.Venn.).

Dit verschil in behandeling tussen de twee vennootschapsvormen vindt wellicht veeleer zijn oorsprong in het id quod plerumque fit in een besloten vennootschap, met name de identiteit tussen eigenaar en bestuurder.

Indien de eigenaar van een BVBA daarentegen een beroep doet op een externe statutaire zaakvoerder kan enkel een statutaire aanpassing die de herroeping vergemakkelijkt, een voldoende tegengewicht geven aan de algemene vergadering.

34. Verzaking aan de remediërende mechanismen, en tijdstip daarvan - Kwijting. Kapitaalvermindering - Inroepen nietigheid - Voorkeurrecht - Herroepbaarheid ad nutum - Wij hebben achtereenvolgens meerdere aanpassingszones beschreven die de wetgever heeft afgegrensd. Zij staan, in de mate waarin hij dat aanduidde, toe om af te wijken van het remediërend mechanisme, meestal in overeenstemming met het belang van de vennootschap. Buiten deze aanpassingszones is het niet mogelijk om een remediërend mechanisme buiten werking te stellen tenzij eraan wordt verzaakt.

De verzaking heeft geen uitwerking indien zij door bedrog is aangetast. Wie bijvoorbeeld de kwijting stemt op zicht van een vervalste jaarrekening, is niet gebonden en kan nog steeds een minderheidsvordering instellen (artikel 284, 290, 554 en 562 W.Venn.).

Het is niet mogelijk op voorhand te verzaken. De verzaking is enkel geldig indien de dwingende bescherming reeds is geactiveerd door de gebeurtenis die het remediërend mechanisme in werking stelt.

De derde-schuldeiser wordt bijvoorbeeld beschermd tegen de negatieve gevolgen van een kapitaalvermindering van zijn debiteur door een wettelijke bepaling die hem het recht geeft een procedure zoals in kort geding in te stellen binnen twee maanden na de publicatie van de beslissing van de algemene vergadering. Deze procedure strekt ertoe hem de betaling van zijn vordering te waarborgen (artikel 317 en 613 W.Venn.). Hij kan niet verzaken aan dit recht dan ná de beslissing tot kapitaalvermindering: pas dan kan de individuele schuldeiser groen licht geven voor de operatie.

Evenzeer kan een aandeelhouder of vennoot niet eerder verzaken aan de formaliteiten van oproeping en termijn voor een algemene vergadering (artikel 268 en 533 W.Venn.) dan in het proces-verbaal zelf van die algemene vergadering. ${ }^{80}$

8o Een dergelijke anticipatieve verzaking is in de praktijk toegestaan aan zaakvoerders, bestuurders en commissarissen (art. 269 en 535 W.Venn.), maar hun aanwezigheid op de algemene vergadering waar ze niet deelnemen aan de besluitvorming is van een andere aard. 
Ook een geldige verzaking sorteert slechts effect wanneer ze wordt verkregen van alle partijen die er belang bij zouden kunnen hebben de bepaling in kwestie in te roepen. Een dergelijke unanieme verzaking is bijvoorbeeld noodzakelijk voor een asymmetrische kapitaalvermindering: indien alle vennoten of aandeelhouders toestemmen, is een afwijking van de evenredige behandeling toegestaan zodat welbepaalde vennoten of aandeelhouders de vennootschap geheel kunnen verlaten zonder dat de andere vennoten aan de vermindering kunnen deelnemen (vgl. artikel 3 I 6 en 6r2 W.Venn.).

De verzaking kan stilzwijgend zijn, zowel in het gemeen recht als in het vennootschapsrecht. Zo wordt de aandeelhouder of vennoot geacht te verzaken aan de nietigheidsprocedure die hij zou kunnen inroepen nadat hij aan een algemene vergadering heeft deelgenomen zonder bepaalde vormgebreken vooraf op te werpen (artikel I78 W.Venn.).

Hoewel de verzaking stilzwijgend kan zijn, geldt de enkele niet-uitoefening van een recht waarvan men geniet daarom nog niet als een verzaking. De aandeelhouder die zijn voorkeurrecht niet wenst te benutten, verliest het niet en kan het alsnog verkopen. De aandeelhouder die niet deelneemt aan de algemene vergadering, of die zich onthoudt van de kwijting, kan nog steeds een vordering tot nietigheid instellen (artikel I78 W.Venn.), of een minderheidsvordering (artikel 290 en 562 lid 3 W.Venn.). Dergelijke passieve beslissingen staan niet toe aan de partij die een zekere bescherming is verschuldigd, om zijn weg voort te zetten zonder de beschermingsprocedure te eerbiedigen.

De verzaking moet dus actief zijn en staat toe, voor zover ze geldig en efficiënt is, om de beschermingsprocedure niet te eerbiedigen, of in ieder geval, om ze niet te voltooien vanaf het ogenblik dat de gebeurtenis die de bescherming in het leven roept zich voordoet.

Een mooi voorbeeld van een dergelijke geldige verzaking buiten de aanpassingszone, is deze aan het voorkeurrecht. Zoals hiervoor werd aangeduid (nr. 34), heeft de wetgever een procedure van uitzondering op het voorkeurrecht uitgewerkt (hetzij afwijking, hetzij beperking) in de naamloze vennootschap: als de algemene vergadering deze scrupuleus naleeft, en goedkeurt met drie vierde van de stemmen, met het belang van de vennootschap als leidraad, dan kan zij een kapitaalverhoging buiten voorkeurrecht met een 75\%-meerderheid goedkeuren (artikel 596-599 W.Venn.).

Voor een naamloze vennootschap die geen beroep doet of heeft gedaan op het spaarwezen ${ }^{8}{ }^{8}$ is het mogelijk deze zware procedure achterwege te laten op

8I In de BVBA heeft het voorkeurrecht een absoluut karakter: zijn opheffing of beperking is niet toegestaan. Een unanieme verzaking kan dus enkel nuttig zijn om het verstrijken van de termijn van vijftien dagen niet te moeten afwachten om te beginnen aan de tweede ronde (inschrijving door personen die zijn toegelaten door de wet of de statuten als vennoten) (art. 3Io W.Venn.). 
voorwaarde dat elke aandeelhouder met kennis van zaken aan zijn voorkeurrecht verzaakt. Iedereen aanvaardt dat een dergelijke verzaking niet mogelijk is vóór het recht ontstaat, dat wil zeggen dat het eerste nuttige ogenblik ná de beslissing van de algemene vergadering komt om het kapitaal te verhogen met eerbiediging van het voorkeurrecht. Indien de aandeelhouder vóór die datum bevestigt dat hij zijn voorkeurrecht niet zal uitoefenen, heeft dat enkel de juridische waarde van een gentlemen's agreement.

Het is onmogelijk om geldig te verzaken aan een regel die niet enkel private belangen beschermt, maar die ook aan de openbare orde raakt (vgl. artikel I78 W.Venn.).

Voor zover zij nog steeds van openbare orde wordt geacht,,$^{82}$ kan de herroepbaarheid ad nutum van de bestuurder dus niet het voorwerp uitmaken van een geldige verzaking door de vennootschap. Dat wil zeggen dat elke overeenkomst die - zelfs ná de herroeping gesloten - van aard zou zijn om de vennootschap te doen verzaken aan het beginsel van de herroepbaarheid ad nutum, nietig is (zie hierna, nr. 38).

Evenzeer is het onvoorstelbaar dat een vennoot of een aandeelhouder zelfs op het ogenblik dat zijn recht op inzage is ontstaan, zou verzaken aan het vennootschappelijk recht om kennis te nemen van de maatschappelijke documenten of van de bijzondere verslagen (artikel 283 en 553 W.Venn.).

Zoals gezegd (hiervoor, nr. 5) zijn er gevallen zoals dat van individueel verworven rechten waarin de efficiëntie van de statuten moet worden genuanceerd omwille van de contractuele aard van het engagement dat zij bevatten. Het zijn de gevallen waarin het enkel met instemming van betrokkene(n) is toegestaan om een clausule in te voegen of te wijzigen.

Deze hypothese moet worden onderscheiden van de hypothese van de zelfs unanieme verzaking: het dient nergens toe om deze verzaking in de statuten in te voegen, omdat die invoeging alleen reeds het bewijs is van de anticipatie van de gebeurtenis die de bescherming in het leven roept, en dus van haar ongeldigheid.

Indien een dergelijke verzaking plaatsvindt tijdens de algemene vergadering die de beslissing neemt die de bescherming van het remediërend mechanisme doet ontstaan, is het noodzakelijk om in het proces-verbaal van die vergadering te akteren dat elke aanwezige of vertegenwoordigde vennoot of aandeelhouder verklaart om met kennis van zaken te verzaken aan zijn recht. Bovendien moet de aanwezigheidslijst

82 Cass. I3 april I989, TRV I989, 326, m.nt. M. Wyckaert en m.nt. F. Bouckaert; TBH I989, 878; RW I989-90, 253; JT I990, 75I, m.nt. D. Michiels; RCJB, I99I, 205, m.nt. J.M. Nelissen Grade; JDSC I999, 96, ondanks de kritiek vanuit de rechtsleer en de praktijk die zich de facto zo ontwikkelde dat er van het beginsel weinig overblijft, maar dat is een andere discussie (zie bijvoorbeeld K. Geens, M. Wyckaert, C. Clottens, F. Parrein, S. De Dier en S. Cools, m.m.v. F. Jenne en A. Steeno, 'Overzicht van rechtspraak - vennootschappen (I999-20I0)', TPR 20I2, nr. I6I, p. 245; S. Cools, 'Europe's Ius Commune on Director Revocability', ECFR 20II, p. I99-234). 
worden getekend door de vennoten of aandeelhouders. De beslissing is immers niets anders dan de som van de individuele verzakingen.

\section{Doorwerking van aandeelhoudersovereenkomsten in het vennootschapsrecht}

35. Overzicht - In dit onderdeel van het preadvies wordt nader ingegaan op twee typen van overeenkomsten die vaak worden aangegaan in de vennootschapsrechtelijke context, met name de stemovereenkomst en de overeenkomst met betrekking tot de overdracht van aandelen. ${ }^{8}$ Er wordt in het bijzonder ingegaan op de vraag in welke mate de contractuele afspraken tussen partijen impact hebben op de vennootschapsrechtelijke spelregels, dan wel een halt worden toegeroepen door diezelfde vennootschapsrechtelijke spelregels.

Voor beide is opmerkenswaard dat ze in het Wetboek van vennootschappen (beperkt) zijn geregeld, ${ }^{84}$ maar dat ze voorheen al bestonden in de praktijk. De geldigheid van stemovereenkomsten was daarbij een steeds wisselende kwestie; over overdrachtsbeperkende afspraken is van oudsher veel minder te doen. Dat ze een regeling kennen, betekent in elk geval dat de vennootschapswetgever het nodig heeft gevonden de contractuele afspraken te kaderen binnen het vennootschapsrecht, en dus aan bepaalde grenzen te onderwerpen. Daarmee is niet gezegd dat dit wettelijk kader volledig is.

83 Over deze typen van overeenkomsten verschenen relatief recent twee eerdere praktijkgerichte maar goede monografieën (Coibion, Les conventions d'actionnaires en Pattyn, Aandeelhoudersovereenkomsten). Beide auteurs bedden hun betoog mooi in in literatuur en (weliswaar zeer beperkte gepubliceerde) rechtspraak. Dit laat ons toe om ons eigen voetnotenapparaat wat te beperken door naar deze publicaties te verwijzen; de lezer vindt daar alle verdere verwijzingen.

84 Voor de stemovereenkomst voor de vennoten/aandeelhouders, zie art. 28I (BVBA) en 55I (NV) W.Venn. (gelijkluidende bepalingen); voor overdrachtsregelingen zie art. 510-5I2 W.Venn. Naar Belgisch recht is het besloten karakter van de BVBA nog steeds erg streng geregeld (zie art. 249-25I W.Venn.), algemeen wordt aanvaard dat men deze regeling statutair enkel strenger kan maken en niet afzwakken. Het is binnen deze grenzen nog steeds mogelijk om de wettelijke beperkingen aan te vullen met conventionele overdrachtsbeperkingen (zie daarover R. Aydogdu, 'Les clauses statutaires d'agrément dans les s.p.r.l.: “aménager n'est pas dénaturer”, JT 2008, I65). Het W.Venn. bevat geen bijzondere regels hierover, maar grosso modo volgt de praktijk de beginselen inzake de NV. Wat de CVBA betreft, ook zij kent een wettelijk overdrachtsregime (art. 362-376 W.Venn., inclusief uittredingen en uitsluitingen) dat sterk is gekleurd door de kapitaalvariabiliteit die deze vennootschapsvorm kenmerkt. In de praktijk wordt het besloten karakter dat art. 366 W.Venn. als beginsel vooropstelt, veel soepeler ingevuld dan bij de BVBA. Ook in de CVBA kunnen deze wettelijke regels gepaard gaan met op het model van de NV gesteunde conventionele overdrachtsafspraken. De CVBA kent geen regels inzake de uitoefening van het stemrecht, wat wordt verklaard door de grote vrijheid die de vennoten ter zake genieten (C. en K. Van Hulle, De coöperatieve vennootschap, Antwerpen: Kluwer I989, nr. 27I, p. I93195). Dat neemt niet weg dat de basisprincipes die aan de regeling van stemovereenkomsten in de NV ten grondslag liggen, ook naar de CVBA moeten worden doorgetrokken; F. Hellemans, De algemene vergadering. Een onderzoek naar haar grondslagen, haar bestaansreden en de geldigheid van haar besluiten, Kalmthout: Biblo 200I, nr. III, p. I46 (verder aangehaald als Hellemans, De algemene vergadering). Gemakshalve verwijzen we in onze verdere bespreking steeds naar de NV. 


\section{I Stemovereenkomsten}

36. Inleiding - Stemovereenkomsten kunnen worden gedefinieerd als overeenkomsten die de uitoefening van het stemrecht op de algemene vergadering of in het bestuursorgaan van een vennootschap op directe of indirecte wijze regelen, en waarbij minstens één aandeelhouder is betrokken. ${ }^{85}$ De afspraak kan slaan op de rechtstreekse wijze waarop ter vergadering wordt gestemd (ja, neen, onthouding; stemmen op instructie - al dan niet eenmalig of beperkt tot bepaalde agendapunten), maar kan ook betrekking hebben op onrechtstreekse of begeleidende maatregelen (bijvoorbeeld een (al dan niet) bindende voorafgaande stemming in kleine groep, of aanvaarding van andere - meestal strengere - dan de in de statuten vastgelegde meerderheden). ${ }^{86}$ Ons uitgangspunt voor de analyse is dat deze stemovereenkomsten uit hun aard niet in de statuten worden opgenomen. ${ }^{87}$

De Belgische doctrine heeft het lang moeilijk gehad met stemovereenkomsten, hoewel ze in de praktijk wijdverspreid waren. ${ }^{88}$ Dat heeft uiteraard te maken met het wezenlijke belang dat aan het stemrecht toekomt: (I) de aandeelhouder staat een groot deel van zijn beheersautonomie af aan een raad van bestuur (van het gemeen recht afwijkend beginsel, zie hiervoor, nr. 9), en (2) hij onderwerpt zich aan het meerderheidsbesluit (van het gemeen recht afwijkend beginsel, zie hiervoor, nr. 9) voor dat stukje autonomie dat hij wel behoudt, met name zijn proportionele inspraak in de algemene vergadering (evenredigheid als onrechtstreekse doorwerking van het gemeen recht, zie hiervoor, nr. 28). De stemovereenkomst doorbreekt dit evenwicht, doordat de aandeelhouders anticipatief verzaken aan de persoonlijke uitoefening van hun stemrecht. De vraag is dan hoe men tot een nieuw evenwicht komt.

De spreidstand tussen doctrine en praktijk was moeilijk vol te houden, en is uiteindelijk beslecht door het Hof van Cassatie in het arrest Bouccin van 13 april $1989,{ }^{89}$ dat

85 I. Corbisier, 'La société et ses associés', in: Droit des sociétés: les lois des 7 et 13 auril 1995, Brussel: Bruylant I995, p. I68-I69; B. Feron, 'Les conventions d'actionnaires après la loi du I3 avril I995', TBH I996, 697; P. Van Hooghten, 'Aandeelhoudersovereenkomsten na de wet van I3 april I995', DAOR I997, 54; O. Caprasse en R. Aydogdu, 'Contrôle et pactes d'associés', in: X (ed.), Contrôle, stabilité et structure de l'actionnariat, Brussel: Larcier 2009, p. I30; Coibion, Les conventions d'actionnaires, p. 77; Pattyn, Aandeelhoudersovereenkomsten, nr. I76, p. I29.

86 H. Braeckmans en R. Houben, Handboek vennootschapsrecht, Antwerpen: Intersentia 2012 (verder aangehaald als Handboek vennootschapsrecht), nr. 799, p. 432.

87 Een versterkt meerderheidsquorum of een vetorecht dat statutair is verankerd, stelt andere vragen (Geens en Wyckaert, Algemeen deel, nr. 29, p. 50-5I en nr. 43, p. 65-68).

88 Voor een overzicht daarvan: M. Wyckaert, 'De conventionele bescherming van de minderheidsaandeelhouders', in: De bescherming van de minderheidsaandeelhouder, TRV, bijzonder nummer I988, IV; J.M. Nelissen Grade, 'De la validité et de l'exécution de la convention de vote dans les sociétés commerciales', noot onder Cass. I3 april I989, RCJB I99I, 205; Hellemans, De algemene vergadering, nr. 89-IIo, p. II8-I46; C. Clottens, Proportionaliteit van stemrecht en risico in kapitaalvennootschappen, Antwerpen: Biblo 2012, nr. 135, p. I38-I39; Pattyn, Aandeelhoudersovereenkomsten, nr. I70-I74, p. 125 -I 28 .

89 Cass. I3 april ı989, TRV I989, 326, m.nt. M. Wyckaert en m.nt. F. Bouckaert, TBH I989, 878, RW I989-90, 253, JT I990, 75I, m.nt. D. Michiels, RCJB, I99I, 205, m.nt. J.M. Nelissen Grade, JDSC 1999, 96. 
stemovereenkomsten binnen bepaalde grenzen toelaatbaar achtte. Deze grenzen werden uiteindelijk, in I99I en I995, grotendeels gecodificeerd, wat elke twijfel over de principiële geldigheid ervan wegnam (zie ook hiervoor, nr. 5). Zo heeft de wetgever een aanpassingszone gecreëerd (zie hiervoor, nr. 8), waarin het belang van de vennootschap (zie hiervoor, nr. 23) het centraal criterium is dat toelaat de verzaking aan de stemautonomie van een aandeelhouder tijdelijk te rechtvaardigen (zie hiervoor, nr. 29 in fine).

37. Partijen - Het staat aandeelhouders volledig vrij om stemovereenkomsten aan te gaan, en daarbij slechts bepaalde dan wel alle andere aandeelhouders te betrekken. Een stemovereenkomst tussen alle aandeelhouders laat weliswaar toe bepaalde afspraken aan het publiek zicht te onttrekken, maar indien men niet meteen de vennootschapsrechtelijke meerderheidsregels mee importeert, is men gebonden aan de gemeenrechtelijke unanimiteit voor elke wijziging (vgl. ook hiervoor, nr. 2I).

Een aandeelhouder kan ook een stemafspraak aangaan met een derde. Hoewel dat niet met zoveel woorden uit de wettekst blijkt, is men het erover eens dat ook deze overeenkomsten zijn onderworpen aan de spelregels die tussen aandeelhouders gelden..$^{\circ}$

In de Belgische praktijk is het geen traditie om de vennootschap zelf partij te laten worden bij een stemovereenkomst, tenzij voor kennisgeving, of omdat zij bepaalde verplichtingen zou opnemen rond de praktische organisatie van de stemovereenkomst (bijvoorbeeld bewaargeving). Dat heeft onvermijdelijk impact op de doorwerking van stemovereenkomsten (zie hiervoor, nr. 5 en hierna, nr. 4I). De genoteerde NV moet het bestaan van stemovereenkomsten overigens in haar jaarverslag vermelden, ${ }^{9 \mathrm{I}}$ wat lijkt te veronderstellen dat ze van het bestaan ervan op de hoogte moet worden gebracht. Een duidelijke algemene informatieverplichting vanwege aandeelhouders aan hun genoteerde vennootschap bestaat nochtans niet. ${ }^{22}$

38. Wettelijke regeling vanuit het vennootschapsrecht - Artikel 55I W.Venn. legt de volgende beperkingen op aan stemovereenkomsten:

90 Het arrest Bouccin betrof een stemovereenkomst tussen een erfgenaam (aandeelhouder geworden door de erfenis) en een erflater, en had de vorm aangenomen van een last op de erfenis. Andere, meer typerende voorbeelden zijn stemafspraken tussen een aandeelhouder-schuldenaar en diens schuldeiser, een aandeelhouder-optiegever en diens optiehouder, de stembeperkingen die tussen de signing en de closing van een aandelenverkoop tussen de koper en de verkoper van de aandelen worden afgesproken.

9I Art. 34, $6^{\circ} \mathrm{KB}$ I4 november 2007 betreffende de verplichtingen van emittenten van financiële instrumenten die zijn toegelaten tot de verhandeling op een gereglementeerde markt, in uitvoering van art. Io lid I van Richtlijn 2004/25/EG van 2I april 2004 betreffende het openbaar overnameaanbod.

92 Vgl. met art. 63I \$ 2 en 632 \$ 2 W.Venn., die voor kruisparticipaties wel in kennisgevingsverplichtingen voorzien. 
Stemovereenkomsten moeten in de tijd zijn beperkt.93 Dit wordt beschouwd als een vertaling van de vennootschapsrechtelijke regel dat een aandeelhouder niet het recht mag worden ontzegd deel te nemen aan de maatschappelijke besluitvorming. ${ }^{94} \mathrm{De}$ regel van gemeen contractenrecht dat een overeenkomst slechts wijzigbaar is als alle contractspartijen daarmee instemmen, wordt in het rechtspersonenrecht opzijgeschoven door het meerderheidsbesluit: ${ }^{95}$ wie zich dan toch onderwerpt aan die wettelijke afwijkende regel van het meerderheidsbesluit in de volkomen rechtspersoon, mag niet geheel of definitief verzaken aan zijn inspraak in de totstandkoming daarvan. In onze classificatie (hiervoor, nr. 8) gaat het om een onrechtstreekse doorwerking van het gemeen recht (de verzaking mag niet definitief zijn) op een vennootschapsrechtelijke afwijking (het meerderheidsbesluit) op het gemeen recht (unanimiteit). Toch blijft het al met al een vaag criterium..$^{6}$

93 Daarbij bestaat discussie over de vraag of een stemovereenkomst die niet in de tijd is beperkt meteen nietig is (in die zin o.m. Hellemans, De algemene vergadering, nr. 98, p. I28, en nr. II2II3, p. I46-I49; C. Clottens, Proportionaliteit tussen stemrecht en risico in kapitaalvennootschappen, Antwerpen: Biblo 20I2, nr. I37, p. I4I; Pattyn, Aandeelhoudersovereenkomsten, nr. 179, p. I34) dan wel onder de gemeenrechtelijke regel valt dat ze kan worden opgezegd mits met inachtneming van een redelijke opzeggingstermijn (in die zin: F. Bouckaert, Notarieel Vennootschapsrecht - NV en BVBA (Deel I in de reeks Notarieel Recht), Antwerpen: Kluwer 2000, p. 434-437; Y. De Cordt, 'Le droit de vote', in: Le statut des actionnaires (S.A., S.P.R.L. et S.C.R.L.) - questions spéciales, Brussel: Larcier 2006, p. I36; M. Wyckaert, 'Overdrachtsbeperkingen en stemrecht', in: De nieuwe vennootschapswetten van 7 en 13 april 1995, Kalmthout: Biblo I995, nr. 34, p. II6) dan wel door de rechter kan worden gered door reductie van de duur tot een aanvaardbare duurtijd (in die zin: C. Staudt en P. Kileste, 'Le statut des administrateurs et les pactes d'actionnaires', in: Les conflits au sein des sociétés commerciales ou à forme commerciale, Brussel: Editions Jeune Barreau 2004, p. 4I; O. Caprasse en R. Aydogdu, 'Contrôle et pactes d'associés', in: X (ed.), Contrôle, stabilité et structure de l'actionnariat, Brussel: Larcier 2009, p. I85; Coibion, Les conventions d'actionnaires, p. 8I). Wel is men het erover eens dat een redelijke duurtijd afhankelijk van de omstandigheden tot meer dan twintig jaar kan uitlopen, en dat stilzwijgende verlengingen kunnen op voorwaarde, in de strenge nietigheidsvisie, dat ze niet onbeperkt in de tijd worden.

94 Cass. I3 april I989, TRV I989, 326, m.nt. M. Wyckaert en m.nt. F. Bouckaert; TBH I989, 878; RW I989-90, 253; JT I990, 75I, m.nt. D. Michiels; RCJB I99I, 205, m.nt. J.M. Nelissen Grade; JDSC I999, 96; zie specifiek J.M. Nelissen Grade, 'De la validité et de l'exécution de la convention de vote dans les sociétés commerciales', noot onder Cass., I3 april I989, RCJB I99I, 224-229, nr. I8-27; P. De Wolf en B. Feron, 'Les conventions d'actionnaires - Une évolution inachevée', DAOR 2I/I99I, p. 36-37, nr. 20-22; M. Wyckaert, 'Overdrachtsbeperkingen en stemrecht', in: De nieuwe Vennootschapswetten van 7 en 13 april 1995, Kalmthout: Biblo 1995, p. III, nr. 23.

95 Geens en Wyckaert, Algemeen deel, p. 43, nr. 17 en p. 50, nr. 29.

96 Zie bijvoorbeeld de niet steeds overtuigende analyse van Hellemans, De algemene vergadering, nr. I06, p. I4I-I43: een overeenkomst waarbij aandeelhouders bindende afspraken maken over hun stemgedrag voor een bepaalde materie of in een bepaalde vergadering zou wel geldig zijn, maar de stemovereenkomst die resulteert in de niet-aanwending van stemrechten (die bijvoorbeeld de vorm kan aannemen van de verplichting zich niet ter vergadering aan te melden) zou niet kunnen. Nochtans is het verschil tussen een vennoot die er zich (bijvoorbeeld na een voorafgaande stemming) toe verbindt zich te onthouden of zich niet aan te bieden in de resultaten veelal onbestaand (voor gekwalificeerde meerderheden telt de onthouding evenwel als een neestem, terwijl een afwezigheid zich alleen in het quorum laat voelen (zie Hellemans, De algemene vergadering, nr. 552-554, p. 612-6r6)). Dat een vennoot zich ook nooit zou kunnen verbinden om overeenkomstig de instructies van een andere vennoot te stemmen (nr. II5, p. I5I) overtuigt ons niet (zo wordt bijvoorbeeld wel aanvaard dat de pandgevende aandeelhouder er zich toe kan verbinden op instructie van de pandhouder te stemmen, wat impliciet ligt vervat in art. II van de Wet Financiële Zekerheden van I5 december 2004). Het komt ons voor dat alleen een langdurige en systematische verbintenis om zich niet ter vergadering aan te bieden c.q. een andere vennoot 
Nog vager en derhalve moeilijker te omschrijven is de voorwaarde dat stemovereenkomsten steeds in het belang van de vennootschap moeten zijn, terwijl in het gemeen recht de geldigheid van de interne oorzaak van een overeenkomst wordt beoordeeld op het ogenblik dat zij wordt aangegaan ${ }^{97}$ (over de notie 'belang', zie hiervoor, nr. 23). Het belang is ook hier de toetssteen voor het evenwicht dat de wetgever heeft gewild tussen de onrechtstreekse doorwerking van het gemeen recht (evenredig stemrecht) en de contractuele aanpassing daarvan (onderwerping van dat evenredig stemrecht aan contractuele beperkingen).$^{98}$ Verschillende auteurs hebben nog vóór de wetswijziging van I99I gepleit voor de vervanging van deze toetssteen door klassieke gemeenrechtelijke criteria, die evenzeer een evenwicht tot stand kunnen brengen, zoals de goede trouw ${ }^{99}$ of het misbruik van meerderheid, ${ }^{\text {10o }}$ maar werden door de wetgever niet gehoord.

De literatuur worstelt bovendien met de wijze waarop dit evenwicht wettelijk werd vertaald, met name als een 'moving target'. Immers, wat bij het aangaan van de overeenkomst perfect verzoenbaar was met het vennootschapsbelang, is dat misschien drie jaar later niet langer. Sommige auteurs verzachten de pil door te aanvaarden dat het volstaat dat een stemafspraak niet tegen het vennootschapsbelang ingaat; andere vereisen wel degelijk dat de stemovereenkomst voortdurend positief het vennootschapsbelang moet benaarstigen. ${ }^{\text {Ior }}$ Een veruitwendiging van dat belang in een preambule van de overeenkomst kan de toetsing vergemakkelijken, maar verhoogt meteen het risico dat bij een evoluerend belang de overeenkomst aanvechtbaar wordt. Ondanks al deze kopzorgen van de auteurs lijkt het in de praktijk mee te vallen: uit de gepubliceerde rechtspraak blijken hierover geen betwistingen.

Uiteraard mag een stemovereenkomst evenmin strijdig zijn met het Wetboek van vennootschappen. Het klassieke voorbeeld is de nietigheid van een stemovereenkomst die afbreuk doet aan het ad nutum karakter van het bestuursmandaat (artikel 518 § 3

blind te gehoorzamen, ongeacht de agenda en de omstandigheden, onder dit verbod zou kunnen vallen.

97 P.H. Ghekiere, 'Overdrachtsbeperkingen op aandelen en stemafspraken in naamloze vennootschappen na de reparatiewet', Acc. Bedr., Themanummer Reparatiewet Deel I, september I995, p. 59; Hellemans, De algemene vergadering, nr. II3, p. I48-I50; L. Cornelis, Algemene theorie van de verbintenis, nr. II5 e.v., p. I40 e.v.; Van Gerven en Covemaeker, Verbintenissenrecht, p. 8o-8I; E. Janssens en F. Keskin, 'Aandelen. Een overzicht van de principes en een aantal toepassingen', CABG 2009/3, p. 58; Pattyn, Aandeelhoudersovereenkomsten, nr. I8I, p. I36.

98 Geens en Wyckaert, Algemeen deel, nr. 31, p. 52.

99 K. Geens, 'Beschermingsconstructies: enkele recente evoluties', in: Openbaar bod en beschermingsconstructies, Kalmthout: Biblo i99o, p. I07.

Ioo J.M. Nelissen Grade, 'De la validité et de l'exécution de la convention de vote dans les sociétés commerciales', RCJB I99I, nr. 5I-53, p. 244-246; O. Caprasse en R. Aydogdu, 'Contrôle et pactes d'associés', in X (ed.), Contrôle, stabilité et structure de l'actionnariat, Brussel: Larcier 2009, p. I92.

IoI Het feit dat art. 55I $\S \mathrm{I}$, lid 2, $\mathrm{I}^{\circ}$ W.Venn. een stemovereenkomst die strijdt met het vennootschapsbelang nietig acht, pleit voor de eerste opvatting. Zie voor een overzicht van de verschillende opvattingen, Pattyn, Aandeelhoudersovereenkomsten, nr. I8I, p. I35, die zelf denkt dat gelet op de flexibele invulling van de notie vennootschapsbelang en de marginale toetsing van het gebruik door een aandeelhouder van zijn stemrecht, het verschil in de praktijk beperkt blijft. Als men het belang vervangt door de goede trouw of het verbod tot misbruik van meerderheid (zie hiervoor, voetnoot 98 en 99), komt men overigens tot een vergelijkbaar resultaat. 
W.Venn.), ${ }^{\text {102 }}$ bijvoorbeeld door een versterkte meerderheid op te leggen. In diezelfde logica moeten ook stemovereenkomsten die soepelere meerderheden opleggen dan het Wetboek van vennootschappen dwingend voorschrijft (zie hiervoor, nr. 2I ${ }^{\mathrm{I03}}$ in de regel nietig worden verklaard: de contractuele vrijheid stuit daar op de grenzen van de wettelijke en dus dwingende rechtstreekse doorwerking (gekwalificeerde meerderheid) die de afwijking (meerderheidsbesluit) op het gemeen recht (unanimiteit) corrigeert (zie hiervoor, nr. 8). ${ }^{104}$ Nochtans zijn de grenzen van dit verbod relatief: in een voorafgaande bindende stemming tussen aandeelhouders die een beperkter deel van het kapitaal vertegenwoordigen waarbij dezelfde absolute meerderheidsregels worden gehanteerd, worden de tegenstemmen de facto omgezet in stemmen voor, en vertekenen zij dus de dwingende meerderheidsregels. Desondanks maakt de literatuur geen bezwaar tegen dit soort voorstemmingen. ${ }^{105}$ De analyse van Hellemans, daarin gevolgd door Clottens, dat stemovereenkomsten uit hun natuur moeilijk verzoenbaar zijn met het wettelijk beginsel 'één aandeel, één stem' (artikel 54I lid I W.Venn.), dat wij vertalen als een onrechtstreekse doorwerking van het gemeen recht, is dus correct, ${ }^{106}$ maar wijst allicht eerder op de relativiteit van dat beginsel dan op een inconsistente wettelijke regeling van stemovereenkomsten (zie ook hiervoor, nr. 29).

Dat stemovereenkomsten ook de statuten moeten respecteren, is een evidentie, ${ }^{\text {Io }}$ maar staat niet met zoveel woorden in de wet.

Ook stemovereenkomsten waarbij de aandeelhouder zich ertoe verbindt zijn stemrecht uit te oefenen overeenkomstig de richtlijnen van de vennootschap, van een dochtervennootschap of van een de organen van die vennootschappen, dan wel zich jegens deze vennootschappen of haar organen ertoe verbindt de voorstellen van de organen van de vennootschap zonder meer goed te keuren, zijn nietig. Het

I02 Voorlopig wordt daaraan nog vastgehouden door constante cassatierechtspraak die dit beginsel van openbare orde noemt-zie ook hiervoor, nr. 34 .

I03 De oefening of een bepaalde wettelijke meerderheidsregel dwingend is mag niet aan de hand van automatische reflexen gebeuren: zo hebben wij hiervoor (nr. I4) betoogd dat een versoepeling van de regels die de ontbinding van de vennootschap vergemakkelijken, wel geldig zou moeten zijn, omdat aldus de vennootschapsrechtelijke afwijking (meerderheidsbesluit) terug toenadering zoekt tot het gemeen recht (elke vennoot heeft het recht de vennootschap eenzijdig op te zeggen). Met andere woorden, het intuitu personae-karakter van een contractueel verband uit het gemeen recht wint het hier van de unanimiteitsregel (zie ook Geens en Wyckaert, Algemeen deel, nr. 22, p. 47).

I04 Zie ook Geens en Wyckaert, Algemeen deel, nr. I6, p. 4I. Dit betekent bijvoorbeeld dat een stemovereenkomst die een statutenwijziging toelaat bij gewone meerderheid niet geldig is.

I05 Dit zou niet het geval zijn mocht de voorstemming proportioneel worden omgezet in de werkelijke stemming, maar dan heeft ze enkel een indicatieve betekenis.

Io6 Hellemans, De algemene vergadering, nr. 93, p. I2I; C. Clottens, Proportionaliteit tussen stemrecht en risico in kapitaalvennootschappen, Antwerpen: Biblo 20I2, nr. I35, p. I39. Het is interessant om een verband te leggen met de visie van Hellemans dat het afnemend belang van de algemene vergadering als beslissingsorgaan binnen de vennootschap stemovereenkomsten aanvaardbaar heeft gemaakt (nr. Ior, p. I35 en nr. II7, p. I58).

I07 J.M. Nelissen Grade, 'Goedkeurings- en voorkoopclausules in de naamloze vennootschap. Overeenkomsten betreffende de uitoefening van het stemrecht', in: N.V. en B.V.B.A. na de Wet van 18 juli 1991, Kalmthout: Biblo I992, p. 86, nr. 63. 
remediërend doorwerkend gemeen recht (evenredig stemrecht) wordt hiermee sterk afgeschermd tegen de almacht van het bestuur, die op zijn beurt inbreekt op de beheersautonomie van de eigenaar uit het gemeen recht. ${ }^{108}$

39. Wettelijke regeling vanuit het gemeen recht - In één pennenstreek wordt aanvaard dat stemovereenkomsten ook moeten beantwoorden aan de gemeenrechtelijke beginselen, en dat brengt meteen een heel gamma van mogelijke bijkomende nietigheidsgronden in het gelid. ${ }^{109}$ Dat een stemovereenkomst die neerkomt op stemmenkoop de openbare orde miskent, en dus een ongeoorloofde oorzaak is, is evident. ${ }^{\text {II }}$ Maar ook miskenning van de gemeenrechtelijke geldigheidsvoorwaarden (onbekwaamheid en de wilsgebreken (bedrog, dwaling)) leiden tot de gebruikelijke - relatieve - vernietigbaarheid van de stemovereenkomst, en via die weg mogelijk ook van de beslissing van de algemene vergadering (zie nr. 40), zelfs in die gevallen waarin de gemeenrechtelijke ongeldigheid waarmee de stemovereenkomst is behept, op geen enkele manier te maken heeft met de vennootschap of de andere aandeelhouders (bijvoorbeeld een bij het aangaan van de stemovereenkomst ongeldig vertegenwoordigde minderjarige aandeelhouder; of nog een financiële instelling die bedrog pleegt wanneer zij van haar pandgevende schuldenaar een instructierecht op het stemrecht verbonden aan diens aandelen bekomt).

40. Nietige stemovereenkomst, nietige stem - Een stemovereenkomst die zondigt tegen de onder nr. 38 uiteengezette beginselen levert een nietige stem op (artikel 55I § 3 W.Venn.). ${ }^{I I I}$ Men mag allicht aannemen dat dit eveneens het geval is wanneer een gemeenrechtelijke nietigheidsgrond de stemovereenkomst (of haar uitvoering) aantast (nr. 39).

I08 Geens en Wyckaert, Algemeen deel, nr. 17, p. 43-44.

Io9 J. Lievens, De Nieuwe Vennootschapswet (Wet van 18 juli 1991), Gent: Mys \& Breesch I99I, p. I27; J.M. Nelissen Grade, 'Goedkeurings- en voorkoopclausules in de naamloze vennootschap. Overeenkomsten betreffende de uitoefening van het stemrecht', in: N.V. en B.V.B.A. na de Wet van 18 juli 1991, Kalmthout: Biblo 1992, nr. 63, p. 86; R. Nieuwdorp, 'Overeenkomsten tussen aandeelhouders', in: H. Braeckmans en E. Wymeersch (red.), Het gewijzigde vennootschapsrecht 1991, Antwerpen: Maklu 1992, p. 269; J.M.M. Maeijer, 'Stemovereenkomsten van aandeelhouders naar Belgisch en Nederlands recht', in: Liber Amicorum Baeteman, Antwerpen: Kluwer 1997, nr. 4, p. I85; P. Baurain, 'Le point sur les conventions de vote, marqueurs de la contractualisation du mécanisme sociétaire: l'originalité extrastatutaire sera payante', Rev. not.b. 1998, 86; Hellemans, De algemene vergadering, nr. II5, p. I5I; Pattyn, Aandeelhoudersovereenkomsten, p. I32, nr. 178; Braeckmans en Houben, Handboek vennootschapsrecht, nr. 804, p. 434.

IIo J. Van Ryn en P. Van Ommeslaghe, 'Les sociétés commerciales. Examen de jurisprudence (Ig66I97I)', RCJB 1973, 408, nr. 45; L. Weyts, 'De redactie van de aandeelhoudersovereenkomst', in: X. (red.), Liber amicorum Jan Ronse, Brussel: Story-Scientia 1986, p. 424, nr. 17; C. Clottens, Proportionaliteit tussen stemrecht en risico in kapitaalvennootschappen, Antwerpen: Biblo 2012, nr. I38, p. I4I en nr. I42, p. I43.

III Naar de letter van de wet treft de nietigheidssanctie niet de voor onbepaalde tijd aangegane stemovereenkomsten noch de stemovereenkomsten in strijd met het vennootschapsbelang (art. 55I $\S 3$ verwijst niet terug naar $\S$ I lid 2). Over de onenigheid over de sanctie bij schending van de beperkte duurtijd, zie hiervoor, voetnoot 92; er is eensgezindheid dat een stemovereenkomst die niet (langer) het vennootschapsbelang dient c.q. ermee strijdt, nietig is (Pattyn, Aandeelhoudersovereenkomsten, nr. I85, p. I39). Hellemans kwalificeert de uitdrukkelijke nietigheden (\$I lid 3) als absoluut, en die uit § I lid 2 als relatief (De algemene vergadering, nr. II6, p. 154 . 
Een dergelijke nietige stem levert evenwel alleen de nietigheid van de beslissingen van de algemene vergadering tijdens dewelke zij is aangewend op, wanneer zij invloed heeft gehad op de geldigheid van de genomen stemming. ${ }^{112}$ Aldus wordt aansluiting gezocht bij de algemene vennootschapsrechtelijke regels inzake besluitvorming ter algemene vergadering (artikel 64 W.Venn.). ${ }^{113}$ Tenzij de aangetaste stem samenhangt met een onrechtmatige afwezigheid ter vergadering zal de proef in dergelijke gevallen louter rekenkundig zijn: was de nietige stem nodig (aan de zijde van de ja- of van de nee-stemmers ${ }^{\mathrm{II} 4}$ om hetzij de meerderheid hetzij de blokkeringsminderheid te behalen, dan wordt de beslissing nietig.

Ook derden zouden het recht hebben de nietigheid van een stemovereenkomst aan te voeren: van dit recht zullen zij evenwel maar gebruik kunnen maken wanneer zij en het bestaan en de inhoud van de stemovereenkomst kennen, en zij een belang hebben bij de nietigheid. ${ }^{115}$

4I. Relatie tot de statuten - Het wordt vrij unaniem aanvaard dat een stemovereenkomst die de statuten aanvult (over dat begrip hiervoor, nr. 5), of, sterker nog, afwijkt van de statuten (zie hiervoor, nr. 38) op zichzelf geldig is, maar dat die geldigheid zich beperkt tot de partijen bij de stemovereenkomst. ${ }^{\text {I16 }}$ Met andere woorden, een beslissing die de statutaire meerderheden haalt, is vennootschapsrechtelijk geldig genomen, en de partijen die zich contractueel beschermd weten door een sterkere

II2 Met andere woorden, de stem wordt vermoed nietig te zijn, tenzij diegene die haar gehandhaafd wil zien aantoont dat ze geen invloed had op de stemming (J.M. Nelissen Grade, 'Goedkeuringsen voorkoopclausules in de naamloze vennootschap. Overeenkomsten betreffende de uitoefening van het stemrecht', in: N.V. en B.V.B.A. na de Wet van 18 juli 1991, Kalmthout: Biblo I992, nr. 67).

II3 Daarover: B. Tilleman, De geldigheid van besluiten van de algemene vergadering. Het nieuwe artikel 19obis Venn. W., Kalmthout: Biblo I994; Hellemans, De algemene vergadering).

II4 Waarbij men rekening moet houden met de regel dat voor statutenwijzigingen een onthouding een nee-stem is: F. De Bauw, Les assemblées générales dans les sociétés anonymes, Brussel: Bruylant I996, nr. 595, p. 25I; Hellemans, De algemene vergadering, nr. 552-554, p. 612-6r6.

II5 Hellemans, De algemene vergadering, nr. II6, p. I54 en nr. I23, p. I63: het is voor deze auteur een van de redenen om de lege ferenda een vergaande transparantie van stemovereenkomsten te bepleiten (zie ook nr. 37 voor de inmiddels de lege lata gerealiseerde maar beperkte transparantie in genoteerde vennootschappen).

II6 Zie bijvoorbeeld V. Simonart, 'La contractualisation des sociétés ou les aménagements contractuels des mécanismes sociétaires', RPS 1995, 75. Een strengere stelling, maar die inmiddels grotendeels verlaten lijkt, stelde dat een aandeelhoudersovereenkomst die afwijkt van de statuten of haar aanvult op essentiële punten die de werking van de vennootschap aanbelangen, ongeldig is (zo bijvoorbeeld een clausule van proportionele vertegenwoordiging van de aandeelhouders in de raad van bestuur die niet in de statuten is opgenomen): P. Van Ommeslaghe, 'Les conventions d'actionnaires en droit belge', RPS I989, nr. 6532, nr. I9, p. 316-317; J.M. Nelissen Grade, 'De la validité et de l'exécution de la convention de vote dans les sociétés commerciales', RCJB I99I, nr. 56, p. 247; J.M. Nelissen Grade, 'Goedkeurings- en voorkoopclausules in de naamloze vennootschap. Overeenkomsten betreffende de uitoefening van het stemrecht', in: N.V. en B.V.B.A. na de Wet van 18 juli 1991, Kalmthout: Biblo I992, nr. 6o, p. 85; P. De Wolf en B. Feron, 'Les conventions d'actionnaires. Une évolution inachevée', DAOR I99I, nr. 2I, p. 43; H. Laga, Statuten, statutenwijziging en reglement van inwendige orde getoetst aan algemene beginselen van contractenrecht (diss. KU Leuven) I99I, nr. 222-224, p. 264-266; Hellemans, De algemene vergadering, nr. 668, p. 7I3; Pattyn, Aandeelhoudersovereenkomsten, nr. 23-25, p. 15-17; Braeckmans en Houben, Handboek vennootschapsrecht, nr. 809, p. 436. 
meerderheid, kunnen alleen schadevergoeding vorderen van hun medecontractanten (vgl. hiervoor, nr. 5). Omgekeerd - hoewel in de praktijk weinig tot niet voorkomend, maar belangrijk om het principe te schetsen - zou een beslissing die een voldoende contractueel overeengekomen meerderheid verzamelt (bijvoorbeeld $75 \%$ ) die minstens overeenkomt met de wettelijk voorgeschreven meerderheid ${ }^{117}$ maar bij veronderstelling minder dan de statutair voorgeschreven meerderheid (bijvoorbeeld $80 \%)$, niet geldig zijn genomen. Dit zou op dezelfde manier gelden voor een bindende voorafgaande stemming, waarvan de uitslag die niet wordt nageleefd bij de uiteindelijke stemming.

Als alle aandeelhouders partij zouden zijn tot een stemovereenkomst die van de statuten afwijkende meerderheden oplegt, zou men kunnen betogen dat zij aldus impliciet de statuten hebben gewijzigd, zij het zonder naleving van de regels voorgeschreven voor statutenwijziging. De vraag rijst dan onvermijdelijk waarom dit type stemovereenkomsten niet statutair is verankerd: als dat is om derden te benadelen, zou de vennootschap - als zij de overeenkomst al kent - de statuten moeten laten prevaleren, zo niet, dan wordt daaraan - o.i. terecht - getwijfeld ${ }^{118}$ (zie ook hiervoor, nr. 5).

42. Uitvoering in natura - De basisregel in het verbintenissenrecht is dat bij wanprestatie de schuldenaar wordt gedwongen vooralsnog te presteren (uitvoering in natura); slechts wanneer dat onmogelijk is of daardoor niet alle schade zou zijn vergoed, kan (vervangende of bijkomende) schadevergoeding worden toegekend. ${ }^{\text {I9 }}$ Betekent dit dat wanneer een aandeelhouder die zich niet houdt aan een bij veronderstelling geldige stemovereenkomst die niet strijdt met de statuten in de hiervoor (nr. 5 en $4 \mathrm{I}$ ) aangegeven zin, zijn stem moet worden geneutraliseerd en vervangen door een wel aan de overeenkomst conforme stem, en zo ja, hoe moet dit dan gebeuren?

De doctrine lijkt vrij unaniem te aanvaarden dat een aandeelhouder die wordt geconfronteerd met een medecontractant die op het punt staat zijn contractuele verbintenis niet na te leven, hem in kort geding en zo nodig op straffe van een dwangsom anticipatief tot naleving kan dwingen. ${ }^{120}$ Veel rechtspraak is er niet, maar het enige enigszins aansluitende geval ${ }^{121}$ laat nochtans niet veel ruimte: volgens het Hof van

II7 Een stemovereenkomst waarbij een mindere dan de wettelijk voorgeschreven meerderheid wordt afgesproken, is nietig wegens strijdigheid met het W.Venn. (zie hiervoor, nr. 38).

II8 Vgl. Hellemans, De algemene vergadering, nr. 669, p. 7I4-7I5; Pattyn, Aandeelhoudersovereenkomsten, nr. 23, p. I6-I7.

II9 L. Cornelis, Algemene theorie van de verbintenis, nr. 4I4 e.v., p. 523 e.v.; I. Durant, 'Les dommages et intérêts accordés au titre de la réparation d'un dommage contractuelle. Rapport belge', in: M. Fontaine en G. Viney (eds.), Les sanctions de l'inexécution des obligations contractuelles. Etudes de droit comparé, Brussel: Bruylant 200I, p. 307-360; Van Gerven en Covemaeker, Verbintenissenrecht, p. I82-I88.

I20 Hellemans, De algemene vergadering, nr. II9, p. I59; Pattyn, Aandeelhoudersovereenkomsten, nr. I88, p. I43-I44.

I2I Bergen 23 maart I989, RPS I989, I96, TBH I990 326, m.nt. J. Romain, TRV I989, 343, m.nt. L. Neefs en D. Blommaert, 'Bevoegdheid van de rechter in kort geding bij misbruik van 
Beroep te Bergen is het een voorrecht van de aandeelhouder om zijn stem ter vergadering effectief uit te brengen, en kan de rechter dus hoe dan ook pas ingrijpen nadat dat effectief is gebeurd.

Gaat het er dan om een in strijd met een stemovereenkomst uitgebrachte stem achteraf ongedaan te maken, was er traditioneel zelfs in de rechtsleer een grote terughoudendheid, die meteen tot gevolg zou hebben dat, ondanks de algemene erkenning van hun geldigheid, stemovereenkomsten in de praktijk niet evident afdwingbaar zijn. Immers, de stemovereenkomst is een 'res inter alios acta', en is dus slechts in haar bestaan tegenwerpelijk aan derden (artikel II65 B.W.), waaronder de vennootschap en de aandeelhouders die geen partij zijn. Anders gezegd, een in strijd met een stemovereenkomst uitgebrachte stem tast de geldigheid van het besluit van de algemene vergadering niet aan; de benadeelde partij moet het stellen met vervangende schadeloosstelling. ${ }^{122}$ Deze benadering relativeert zeer sterk de principiële aanvaarding van de geldigheid van stemovereenkomsten, en wordt om die reden - vooral sinds hun jurisprudentiële en nadien wettelijke bekrachtiging fel bestreden. ${ }^{\mathrm{I} 3}$

Het enige ons bekende geval uit de rechtspraak is recenter en genuanceerder: het Brusselse Hof van Beroep aanvaardde in $20 \mathrm{II}^{\mathrm{I2} 4}$ de principiële mogelijkheid van herstel in natura ingeval een stem is aangetast door misbruik of een contractuele verbintenis miskent. Dat kan de rechter in elk geval niet door zich in de plaats te stellen van de algemene vergadering en zelf de beslissing te nemen, ${ }^{125}$ maar wel door

minderheidspositie': een minderheidsaandeelhouder geeft publiek signalen dat hij tegen een bepaalde beslissing zal stemmen; de meerderheidsaandeelhouder percipieert dit als een misbruik en eist in kort geding een verbod voor de minderheidsaandeelhouder om tegen te stemmen.

I22 L. Lerut, 'De aandeelhoudersovereenkomst bij notariële akte: why not?', Not. Fisc. M. 20Io, nr. 9I, p. 290; Hellemans, De algemene vergadering, nr. II9, p. I59 en nr. I76, p. 200 (waarbij hij opnieuw het verband legt met de publiciteit); P. De Wolf, 'Exercice du pouvoir et fonctionnement de la SA: un régime de liberté (moins) surveillée', JT 2003, 59I; Y. De Cordt, 'Le droit de vote', in: Le statut des actionnaires (S.A., S.P.R.L. et S.C.R.L.) - questions spéciales, Brussel: Larcier 2006, p. I50; Pattyn, Aandeelhoudersovereenkomsten, p. I42-I43, nr. I87.

I23 Met als koploper J.M. Nelissen Grade, 'De la validité et de l'exécution de la convention de vote dans les sociétés commerciales', RCJB I99I, p. 252-257, nr. 64-72; voor de auteurs die hem nadien volgden, zie Hellemans, De algemene vergadering, nr. II9, p. I6o, vn. (497) en (498), zie verder ook nog Braeckmans en Houben, Handboek vennootschapsrecht, nr. 8o8, p. 435. Hellemans wijst erop dat de zaken eenvoudiger zouden zijn mocht er een wettelijk aanknopingspunt zijn, bijvoorbeeld in art. 64 W.Venn., dat de nietigheidsgronden voor besluiten van de algemene vergadering opsomt. Nochtans biedt art. 64 op de letter beschouwd evenmin een aanknopingspunt voor de nietigverklaring van stemmen die zijn aangetast door een gemeenrechtelijk geldigheidsgebrek (vgl. hiervoor, nr. 39).

I24 Brussel 6 december 20II, TRV 20I3, I45, m.nt. D. Bruloot, 'Kapitaalverhoging: misbruik van meerderheid en herstel in natura bij de onrechtmatige uitoefening van stemrechten' (hervorming van Rb. Brussel I2 augustus 2008, TRV 2013, 158).

I25 Voor die mogelijkheid was eerder gepleit in de doctrine, zij het dan vooral in de context van misbruik van stemrecht: zie J. Ronse en K. Geens, 'Misbruik van minderheidspositie', in: Van vennootschappelijk belang, Zwolle: W.E.J. Tjeenk-Willink I988, p. 246; L. Neefs en D. Blommaert, 'Bevoegdheid van de rechter in kort geding bij misbruik van minderheid' (noot onder Bergen 23 maart I989), TRV I989, 348; D. Bruloot, 'Kapitaalverhoging: misbruik van meerderheid en herstel in natura bij de onrechtmatige uitoefening van stemrechten', TRV 20I3, nr. 8, p. I67. 
schorsing van stemrechten, tijdelijke overdracht van stemrechten aan een lasthebber ad hoc of de invloed van het stemgewicht ongedaan maken. Dat laatste moet gebeuren door 'de tegenstemmen uit de telling te weren'. ${ }^{126}$ Dit is een hele stap vooruit, maar de vraag blijft of de laatste remedie niet nog steeds een te strenge invulling van de rol van de rechter is: als er contractueel geen twijfel mogelijk is hoe er had moeten worden gestemd, lijkt niets te beletten dat de rechter de stemmen inderdaad op die wijze invult, en de telling opnieuw doet. ${ }^{\mathrm{I27}}$

Deze belangrijke opening laat niet alleen de stemovereenkomst als geldige overeenkomst veel beter tot haar recht komen, maar lijkt ook consistenter met de eerder beschreven vanzelfsprekendheid (nr. 39) waarmee wordt aanvaard dat gemeenrechtelijke nietigheidsgronden die de geldigheid van een stemovereenkomst aantasten, leiden tot de nietigheid van de aldus uitgebrachte stemmen en op die manier mogelijk ook tot de nietigheid van het genomen besluit, ook al staan zij inhoudelijk ver af van het vennootschapsleven en de andere aandeelhouders. Door de dubbele gelaagdheid van het besluit van de algemene vergadering (de individuele stemmen vormen allemaal samen een collectief besluit) ondergaan de aandeelhouders die niets te maken hebben met de stemovereenkomst en ook de vennootschap zelf dus toch mogelijkerwijze de gevolgen van haar bestaan. De grens tussen het bestaan van de overeenkomst - die de derde moet ondergaan - en haar inhoud - die de derde niet moet ondergaan - is daardoor niet steeds evident te trekken.

Volledigheidshalve wijzen we erop dat een stemovereenkomst die de statuten aanvult of ermee strijdt, hoewel geldig tussen partijen, omwille van haar niet-tegenwerpelijkheid aan derden, in geen geval vatbaar zou zijn voor uitvoering in natura (zie hiervoor, nr. 5 en 4I).

43. Stemovereenkomsten op het niveau van de raad van bestuur - De rechtsleer is het er vrij unaniem over eens dat stemafspraken op het niveau van de raad van bestuur niet kunnen: ${ }^{128}$ anders dan aandeelhouders, die hun stemrecht mogen uitoefenen ter behartiging van hun eigen belangen, op voorwaarde dat ze er geen misbruik van maken, moeten bestuurders steeds handelen met exclusief het vennootschapsbelang voor ogen. Dit functioneel karakter staat afspraken tussen bestuurders - of

I26 Waarbij het arrest in het midden laat hoe dit precies moet gebeuren. O.i. moeten de betreffende stemmen in een dergelijke redenering overal worden afgetrokken in teller en noemer, zo niet dan blijven zij wegen op zowel het aanwezigheids- als het meerderheidsquorum (zie ook D. Bruloot, 'Kapitaalverhoging: misbruik van meerderheid en herstel in natura bij de onrechtmatige uitoefening van stemrechten', TRV 2013, p. I67, nr. Io).

I27 D. Bruloot, 'Kapitaalverhoging: misbruik van meerderheid en herstel in natura bij de onrechtmatige uitoefening van stemrechten', TRV 20I3, p. I68, nr. II-I2. In dat geval moeten de betreffende stemmen uiteraard niet worden geneutraliseerd.

I28 L. Weyts, 'De redactie van de aandeelhoudersovereenkomst', in: X. (red.), Liber amicorum Jan Ronse, Brussel: Story-Scientia I986, p. 425; J.M. Nelissen Grade, 'De la validité et de l'exécution de la convention de vote dans les sociétés commerciales', RCJB I99I, nr. 6o, p. 249; B. Feron, 'Les conventions d'actionnaires après la loi du I3 avril I995', TBH I996, p. 703; P. De Wolf, 'Exercice du pouvoir et fonctionnement de la SA: un régime de liberté (moins) surveillée', JT 2003, p. 595; Coibion, Les conventions d'actionnaires, p. 84; Pattyn, Aandeelhoudersovereenkomsten, nr. I92, p. I45. 
nog, tussen aandeelhouders en bestuurders - over de wijze waarop bestuurders stemmen in de raad van bestuur in de weg. Zo bijvoorbeeld zijn versterkte meerderheid en/of vetorechten voor een bepaalde bestuurder - die dan wordt geacht in het bijzonder oog te hebben voor de belangen van de aandeelhouders die hij vertegenwoordigt, zonder nochtans het algemene vennootschapsbelang uit het oog te mogen verliezen - wel aanvaard als ze in de statuten zijn opgenomen, maar niet als ze deel uitmaken van een overeenkomst. Of de praktijk dit principe ook gezagsgetrouw navolgt, is nog maar de vraag.

\subsection{Overdrachtsbeperkingen}

44. Inleiding - Hiervoor (nr. 24) zetten we uiteen hoe de vennootschapswetgever via de principiële overdraagbaarheid van de aandelen remedieert aan de continuïteit van de rechtpersoon, die noch door overlijden van een vennoot noch door opzegging kan worden beëindigd. ${ }^{129}$ Met andere woorden, de natuurlijke manier voor een aandeelhouder om de vennootschap achter zich te laten, is de verkoop van zijn aandelen: op die manier wordt het beginsel dat niemand voor zijn leven kan zijn gebonden gerespecteerd, op voorwaarde uiteraard dat de aandeelhouder een koper vindt voor een aanvaardbare prijs. Toch laat het Wetboek van vennootschappen aandeelhouders dan weer toe daaraan te verzaken, zij het binnen vrij strikt getrokken grenzen. Hieronder lichten we die evenwichtsoefening toe.

De klassieke overdrachtsbeperkingen zijn het verbod tot overdracht, het goedkeuringsrecht (de overnemer moet worden goedgekeurd) en het voorkooprecht (de genieters daarvan hebben als eerste het recht de aandelen aan te kopen, hetzij omdat de aandelen zonder meer eerst aan hen moeten worden aangeboden, hetzij dat zij bij een bod van een derde als eerste een koopkans krijgen (al dan niet tegen dezelfde prijs als de derde biedt); soms is dat voorkooprecht ook overdraagbaar). Vaak wordt een goedkeuringsrecht gekoppeld aan een voorkooprecht (als de kandidaat-overnemer wordt geweigerd, hebben de begunstigden van het goedkeuringsrecht vooralsnog het recht om de aandelen zelf te kopen of een alternatieve koper naar voor te schuiven).

Op deze hoofdcategorieën bestaan talloze variaties. ${ }^{130}$

Anders dan stemovereenkomsten kunnen overdrachtsbeperkingen perfect hun plaats vinden in de statuten, dan wel in een aandeelhoudersovereenkomst worden

I29 Geens en Wyckaert, Algemeen deel, nr. 32, p. 52.

I30 Zie de talloze voorbeelden bij onder meer Pattyn, Aandeelhoudersovereenkomsten, p. 35 e.v.; B. Feron, 'Les conventions d'actionnaires après la loi du I3 avril I995', TBH I996, p. 676 e.v.; O. Caprasse en R. Aydodgu, 'Contrôle et pactes d'associés', in: G.A. Dal (ed.), Contrôle, stabilité et structure de l'actionnariat, Brussel: Larcier 2009, p. I22 e.v . 
opgenomen. ${ }^{13 \mathrm{I}}$ Een belangrijke vraag wordt dan uiteraard of dat tot een verschil in juridische behandeling leidt dan wel zou moeten leiden (zie ook hiervoor, nr. 5).

Anders dan voor stemovereenkomsten het geval was, is er nooit een echte controverse geweest rond de aanvaardbaarheid van overdrachtsbeperkingen, op voorwaarde dat zij niet tot gevolg hadden dat aandelen in de NV volledig onoverdraagbaar zouden worden. Toch heeft het tot I9gI geduurd eer de wetgever heeft geprobeerd de contouren van dit beginsel vorm te geven, en deze eerste poging was niet bijzonder geslaagd, want veel te rigide. Met de wet van 13 april 1995 kwam de wetgevende evolutie tot stilstand. ${ }^{132}$ Vele maar niet alle vragen waren daarmee opgelost.

45. Partijen - De doorsnee-afspraken over de overdraagbaarheid van aandelen worden gemaakt tussen aandeelhouders. Niets belet evenwel om derden-partijen bij dergelijke afspraken te betrekken, hetzij als partij, het zij als derde-begunstigde van een recht. Zo bijvoorbeeld (I) de schenker die aandelen schenkt op voorwaarde dat ze niet worden overgedragen, de aandeelhouder die zich ertoe verbindt zijn aandelen bij verkoop aan een derde-geïnteresseerde partij aan te bieden, (2) vrijstelling van goedkeuring of voorkooprechten ten voordele van erfgenamen of van verbonden personen of vennootschappen.

De doctrine lijkt het erover eens te zijn dat wanneer een aandeelhouder zich verbindt jegens een derde, de bijzondere vennootschapsrechtelijke regels geen toepassing vinden: ${ }^{133}$ het beginsel van de vrije overdraagbaarheid beschermt inderdaad uitsluitend de aandeelhouders (hiervoor, nr. 25). Weliswaar lopen deze regels af en toe gelijk aan de regels van gemeen recht, maar ze zijn veel minder uitgewerkt. Dat is minder vreemd dan op het eerste gezicht lijkt: wanneer een aandeelhouder zich jegens een derde verbindt, is dat meestal om redenen die buiten de vennootschapsverhoudingen liggen. Vanuit die optiek is het verdedigbaar dat dergelijke afspraken enkel aan het gemeen recht zijn onderworpen.

Als de overdrachtsafspraken niet in de statuten zijn opgenomen, kan maar hoeft de vennootschap geen partij te zijn, en ook dit is geen standaardpraktijk (zie hiervoor, nr. 5). Wordt ze wel partij, dan is dit meestal om de overeenkomst aan haar

I3I Zie evenwel art. $453,3^{\circ}$ W.Venn., dat voorschrijft dat bijkomende voorwaarden voor de overdracht van aandelen in de oprichtingsakte (of eventuele latere wijzigende akten) moeten worden opgenomen. Volgens sommige auteurs doelt deze verplichting alleen op overdrachtsbeperkingen die van de vennootschap zelf uitgaan: dat belet haar nog steeds niet om partij te worden bij overeenkomsten tussen aandeelhouders die buiten de statuten blijven: V. Simonart, 'La contractualisation des sociétés ou les aménagements contractuels des mécanismes sociétaires', RPS I995, p. I04; D. Willermain, 'Les pactes d'actionnaires: principes fondamentaux - clauses relatives à l'exercice du pouvoir', DAOR 49-2005, I4.

I32 Pattyn, Aandeelhoudersovereenkomsten, nr. 3I-34, p. 2 I-24.

I33 J.M. Nelissen Grade, 'Goedkeurings- en voorkoopclausules in de naamloze vennootschap. Overeenkomsten betreffende de uitoefening van het stemrecht', in: N.V. en B.V.B.A. na de Wet van 18 juli 1991, Kalmthout: Biblo I992, nr. I0, p. 6o; Braeckmans en Houben, Handboek vennootschapsrecht, nr. 92I, p. 496 en de verwijzingen; Pattyn, Aandeelhoudersovereenkomsten, nr. I44, p. Iog en de verwijzingen. 
tegenwerpelijk te maken (zie daarover hierna, nr. 49) of omdat ze een rol speelt in de in de praktische afwikkeling. ${ }^{134}$

Ook het bestaan van dit soort overeenkomsten moet de genoteerde vennootschap melden in haar jaarverslag, ${ }^{135}$ zonder dat deze openbaarmakingsplicht wordt ondersteund door een meldingsplicht van de contracterende aandeelhouders (vgl. hiervoor, nr. 37).

46. Wettelijke regeling vanuit het vennootschapsrecht - De wettelijke regeling, neergelegd in artikel 5io W.Venn., raakt op dezelfde manier overdrachtsbeperkingen in de statuten, de uitgiftevoorwaarden of in een overeenkomst.

Artikel 5 Io W.Venn. regelt in twee regels drie typen van beperkingen op de vrije overdraagbaarheid. In de eerste plaats kan de overdraagbaarheid van aandelen, warrants en converteerbare obligaties ${ }^{136}$ in aandelen zonder meer worden uitgesloten. Een dergelijke volledige blokkering moeten echter in de tijd zijn beperkt en steeds zijn verantwoord in het belang van de vennootschap. Hierover bestaan discussies vergelijkbaar met die rond dezelfde voorwaarden bij stemovereenkomsten (zie hiervoor, nr. 38), zij het dat o.i. het gegeven dat een overdrachtsverbod niet mag strijden met het vennootschapsbelang zonder het actief te moeten promoten, nog vanzelfsprekender lijkt: het gaat hier nog veel meer om de private belangen van de aandeelhouders.

In de tweede plaats laat artikel 5 ro ook goedkeuringsclausules toe (te begrijpen als een clausule waarbij de koper van de aandelen moet worden goedgekeurd door een vennootschapsorgaan, een ad hoc orgaan, of de medecontractanten ${ }^{137}$ of voorkooprechten (breed te begrijpen als elk recht van de/sommige andere aandeelhouders of medecontractanten als het recht om als eerste te kopen), ${ }^{\mathrm{I} 3}$ maar op een voorwaarde:

I34 Bijvoorbeeld als depositaris van de effecten aan toonder (wat met de naderende definitieve afschaffing van effecten aan toonder per I januari 2014 zijn belang verliest), of opdat er geen inschrijvingen in het aandelenregister zouden plaatsvinden in strijd met de overeenkomst.

I35 Art. 34, $6^{\circ}$ K.B. van I4 november 2007 betreffende de verplichtingen van emittenten van financiële instrumenten die zijn toegelaten tot de verhandeling op een gereglementeerde markt, in uitvoering van art. Io lid I van Richtlijn 2004/25/EG van 2I april 2004 betreffende het openbaar overnameaanbod.

I36 Art. 5Io W.Venn. vermeldt ook alle andere effecten die recht geven op de verkrijging van aandelen, waaronder naast converteerbare obligaties ook obligaties met voorkeurrecht of in aandelen terugbetaalbare obligaties, maar deze komen zo goed als nooit voor. Het lijkt wel de bedoeling om alleen instrumenten die recht geven op nieuw uit te geven aandelen onder de regeling te brengen. Verder valt nog te wijzen op de regel dat eventueel afzonderlijk verhandelde voorkeurrechten bij een kapitaalverhoging in geld aan dezelfde (statutaire) overdrachtsbeperkingen zijn onderworpen als het effect waaraan zij zijn verbonden (art. 593 lid 4 W.Venn.).

I37 Dit wordt vaak gekoppeld aan het recht om een alternatieve koper voor te stellen zo goedkeuring wordt geweigerd.

I38 Met talloze varianten: zo kan het bijvoorbeeld gaan om een 'right of first offer', al dan niet tegen een contractueel vastgestelde prijs (er is nog geen bod van een derde), een recht om het bod van een derde te matchen, het recht om bij bod van een derde de aandelen te kopen tegen een contractueel vastgestelde prijs, of nog, het recht om een alternatieve koper voor te stellen. 
de aandelen mogen niet langer dan zes maanden onoverdraagbaar zijn. Met andere woorden, wat ook de uitkomst is van de procedure, heeft de kandidaat-verkoper na zes maanden nog steeds geen uitzicht op de verkoop van zijn aandelen, dan staat het hem zonder meer vrij te verkopen. Dit vertaalt het wettelijk gezocht evenwicht tussen de op het spel staande belangen (kandidaat-overdrager, vennootschap, andere aandeelhouders). ${ }^{139}$ Dit soort afspraken kan onbeperkt in de tijd bestaan, ${ }^{140}$ en er wordt geen verband gelegd met het vennootschapsbelang.

Opmerkenswaard zijn ten slotte de bijzondere regelingen voor overdrachtsbeperkingen in het kader van een openbaar overnameaanbod (artikel 5II-5I2 W.Venn.): in de eerste plaats is een goedkeuring of een recht van voorkoop, ongeacht of het is opgenomen in de statuten dan wel in een aandeelhoudersovereenkomst, niettegenwerpelijk aan de bieder, maar onder ontbindende voorwaarde. Dit betekent dat de aandeelhouders het bod van de bieder mogen aanvaarden, maar dat, wanneer de bieder als koper wordt geweigerd of de begunstigden hun voorkooprecht uitoefenen, de bieder vooralsnog moet wijken, als een witte ridder, die respectievelijk wordt goedgekeurd of tegen wie het voorkooprecht niet wordt ingeroepen, ${ }^{\mathrm{I} 4 \mathrm{I}}$ bereid is hun aandelen te kopen voor ten minste de prijs van het laatste bod. ${ }^{142}$ Ten tweede heeft de vennootschap de mogelijkheid om deze keer uitsluitend statutaire goedkeuringsrechten in te roepen tegen de bieder zonder dat zij een witte ridder in de plaats moet schuiven, als de weigering van de goedkeuring is verantwoord 'op grond van een blijvende en niet-discriminerende toepassing' vastgesteld door de raad van bestuur en vóór het bod aan de FSMA meegedeeld. Voor het behandelde onderwerp verdienen twee punten bijzondere aandacht. Voor de eerste regel maakt de wetgever geen onderscheid tussen statutaire of louter conventionele goedkeurings- of overdrachtsclausules: beide zijn onder dezelfde voorwaarden afdwingbaar, zowel jegens de bieder als jegens hen die zich onder deze rechten verbonden. Weliswaar behouden zij de mogelijkheid hun aandelen over te dragen,maar zij genieten niet van de (minstens) $5 \%$ meerprijs die onder de openbare bodsregels voor zo'n tegenbod wel zou gelden. ${ }^{\mathrm{I} 3}$ De tweede opvallende vaststelling: om een goedkeuringsclausule zonder meer toegepast te zien (zonder verplichting tot gelijk tegenbod) moet ze minstens

I39 Zie de bedenkingen bij Pattyn, Aandeelhoudersovereenkomsten, nr. 74, p. 56.

I40 Pattyn, Aandeelhoudersovereenkomsten, nr. I20, p. 89.

I4I Waaronder ook mag worden begrepen die aandeelhouders die hun voorkooprecht uitoefenen.

I42 Hij ontsnapt dus aan de regel dat elk tegenbod 5\% hoger moet zijn dan het vorige bod (art. 37 K.B. 27 april 2007 op de openbare overnameaanbiedingen). Over de oorsprong van dit compromis, zie K. Geens en H. Laga, 'Overzicht van rechtspraak - Vennootschappen (I986-9I)', TPR I993, II86, nr. 305. Buiten het Assubel-precedent dat aan de oorsprong ligt van de regel, kennen wij geen andere toepassingsgevallen. Op het ogenblik waarop deze regels werden ingevoerd (I989, opname in het W.Venn. (toen nog de Vennootschappenwet) in I99I) was er overigens nog geen sprake van enige verplichting tot bekendmaking van dit soort overeenkomsten. Haar invoering met de Openbaar overnamebodrichtlijn (2004/25/EG, 2I april 2004) had precies tot doel tot een grote transparantie te komen (zie preambule i8, dat het echter enkel heeft over 'door de vennootschap opgezette beschermingsconstructies').

I43 Art. 37 KB 27 april 2007 op de openbare overnameaanbiedingen. 
statutair zijn verankerd. ${ }^{144}$ Op het eerste gezicht is er geen verklaring voor dit verschil, maar de vraag is wat dan logischer zou zijn: alleen in statuten neergelegde overdrachtsbeperkingen onder beide regelingen brengen, dan wel ze beide uitbreiden tot louter conventionele regelingen. De eerste oplossing biedt zich o.i. logischer aan dan de tweede, onder meer in het licht van de tegenwerpelijkheidsproblematiek (zie hiervoor, nr. 5 en hierna, nr. 49).

47. Draagwijdte van de vennootschapsrechtelijke regeling - Deze wettelijke regeling is verre van allesomvattend. Zo wordt bijvoorbeeld door de meerderheid van de rechtsleer aanvaard dat ze niet van toepassing is op winstbewijzen, ${ }^{145}$ die naar Belgisch recht nochtans algemeen als (tweederangs) deelbewijzen (en dus niet als een schuldtitel) worden gekwalificeerd. ${ }^{\mathrm{I} 4^{6}}$ In onze systematiek is dat niet vanzelfsprekend: ook winstbewijshouders ondergaan de continuïteit van de rechtspersoon en zouden dus via de overdracht van hun effecten hieraan moeten kunnen ontsnappen.

Daarnaast bestaat een aantal grijze zones. Zo is bijvoorbeeld betwist of volgrechten zijn onderworpen aan artikel 5Io W.Venn.: ja, volgens sommigen, omdat zij kunnen leiden tot de de facto niet-overdraagbaarheid (omdat de overnemer niet bereid is de aandelen van de volggerechtigden mee over te nemen); neen, volgens anderen, omdat dit slechts resulteert in een specifieke niet-overdraagbaarheid in dit ene geval. ${ }^{\text {I77 }}$ Ook stand stills (begrepen als een verbintenis om de bestaande aandeelhoudersverhoudingen te respecteren) kunnen op die twee verschillende manieren worden benaderd: men mag immers niet verkopen tenzij de anderen proportioneel evenveel verkopen. Volgplichten vallen dan weer buiten de spelregels, want betreffen een verplichting tot overdracht. Ook puts en calls vallen erbuiten, want zijn eenzijdige verbintenissen tot aankoop respectievelijk verkoop van de gever.

Desalniettemin is de hoofdlijn duidelijk: of het nu gaat om statutaire dan wel om conventionele overdrachtsbeperkingen, zij zijn toegelaten maar zij mogen niet leiden tot (een voortdurende) niet-overdraagbaarheid. Dit bewijst het belang dat de wetgever aan de remedie tegen de continuïteit hecht. ${ }^{148}$

I44 Of zijn opgenomen in de authentieke uitgifteakte voor converteerbare obligaties en warrants. Wie deze akten wil kennen moet iets meer moeite doen dan voor statuten, maar ze worden bij uittreksel gepubliceerd en zijn ter inzage ter griffie (art. 588 W.Venn.).

I45 Pattyn, Aandeelhoudersovereenkomsten, nr. 35, p. 25, en de verwijzingen; Braeckmans en Houben, Handboek vennootschapsrecht, nr. 92I, p. 496 en de verwijzingen. Dit is bevestigd door Kh. Hasselt 8 maart 2004, TRV 2004, 249, JDSC 2005, 64 (de rechter oordeelt wel dat ook onder het gemeen recht een blokkeringsverplichting ten aanzien van winstbewijzen die niet in de tijd is beperkt, nietig is, maar gaat - ten onrechte - niet zo ver de gemeenrechtelijke regel toe te passen dat elke overeenkomst van onbepaalde duur kan worden opgezegd met een redelijke opzeggingstermijn).

I46 Wyckaert, Kapitaal in N.V. en B.V.B.A., nr. 886-888, p. 6o6-607; D. Roelens en S. Steevens, 'Winstbewijzen praktisch bekeken', TRV 2010, 285 en de verwijzingen.

I47 Zie het betoog bij Pattyn, Aandeelhoudersovereenkomsten, nr. 49, p. 38, en specifiek over het volgrecht: nr. Io8, p. 8I.

I48 Geens en Wyckaert, Algemeen deel, nr. 32, p. 53. 
Overdrachtsbeperkingen die die wettelijke grenzen niet respecteren, zijn nietig (artikel 55I § 2 W.Venn.), met dien verstande dat goedkeuringsclausules en voorkooprechten die procedureel zo zijn uitgeschreven dat er meer dan zes maanden verstrijken vooraleer de kandidaat-verkoper weet waar hij aan toe is, van rechtswege tot zes maanden worden ingekort (artikel 5 Io lid 4 W.Venn.) - wat er de facto meestal op zal neerkomen dat de aandelen na zes maanden vrij kunnen worden overgedragen. De onduidelijke formulering van artikel 55I § 2 ('aandeelhoudersovereenkomsten' in plaats van 'overdrachtsbeperkingen') heeft sommige auteurs tot de stelling gebracht dat deze nietigheidssanctie niet van toepassing zou zijn op statutaire clausules, ${ }^{\mathrm{I} 99}$ maar er is geen enkel reden om aan te nemen dat de wetgever een dergelijke onderscheiden behandeling, die ook contra-intuïtief aanvoelt, ${ }^{150}$ heeft bedoeld.

48. Wettelijke regeling vanuit het gemeen recht - In zoverre de overdrachtsbeperkingen een louter conventionele grondslag hebben, zijn zij ook onderworpen aan de verbintenisrechtelijke geldigheidsvereisten; zijn zij opgenomen in de statuten, dan moeten die statuten uiteraard geldig zijn aangenomen. In de doctrine wordt aan deze algemene geldigheidsgronden nauwelijks aandacht besteed, en in de rechtspraak kwam zij evenmin al aan de orde. De verklaring daarvoor is allicht dat de impact van een nietige overdrachtsbeperkende clausule op het vennootschapsleven, anders dan voor stemovereenkomsten, niet zo groot is, en zich meestal beperkt tot de discussie tussen de betrokken partijen wie nu eigenaar is. ${ }^{15 \mathrm{I}}$ Overigens speelt ook hier het instrument een rol: een overdrachtsbeperking die in de statuten is opgenomen, is gemakkelijk(er) kenbaar, en zal dus minder snel aanleiding geven tot dwaling of bedrog, of miskenning van de precontractuele informatieverplichtingen..$^{152}$

Soms loopt het gemeen recht parallel aan het vennootschapsrecht (vgl. hiervoor, nr. 47): zo bijvoorbeeld erkent ook ons gemeen recht de principiële overdraagbaarheid van alle zaken die in de handel zijn (artikel I598 B.W.).

49. De keuze van het instrument - Hiervoor (nr. 46) werd er reeds op gewezen dat het Wetboek van vennootschappen zelf aangeeft dat overdrachtsbeperkingen hun

I49 Voor de stellingen pro en contra, zie Pattyn, Aandeelhoudersovereenkomsten, nr. I44, p. Io9.

I50 Zij zou betekenen dat statutaire bepalingen in strijd met de wet niet door nietigheid worden gesanctioneerd ('pas de nullité sans texte', vgl. ook art. $64,5^{\circ}$ W.Venn.), terwijl dit wel het geval zou zijn met identiek dezelfde afspraken buiten de statuten.

I5I De vennootschap zou betrokken kunnen worden als een aandeelhouder wil stemmen of heeft gestemd met aandelen die hij verkreeg in uitvoering van een overdrachtsbeperking die is aangetast door een gemeenrechtelijke nietigheidsgrond (zoals bijvoorbeeld een wilsgebrek) en de overdrager zou anders stemmen of hebben gestemd. In het eerste geval komt het allicht niet tot een uitoefening van het stemrecht (bijvoorbeeld door een schorsing als voorlopige maatregel); in het tweede geval zou het besluit van de algemene vergadering nietig kunnen worden verklaard als de ten onrechte uitgebrachte stem het resultaat heeft beïnvloed. Voor zover wij weten, bestaat hierover geen rechtspraak.

I52 M. Tison, 'Klassieke vraagstukken en nieuwe perspectieven inzake overdrachtsbeperkingen in niet-publieke vennootschappen', in: Knelpunten van dertig jaar vennootschapsrecht, Kalmthout: Biblo I999, p. 6I4-6i6; Pattyn, Aandeelhoudersovereenkomsten, nr. I56, p. II8. 
plaats kunnen vinden in de statuten of in overeenkomsten. Het wetboek regelt evenwel niet de gevolgen van die keuze, en de doctrine is sterk verdeeld.

Er is geen discussie over het feit dat overdrachtsbeperkingen die in een overeenkomst zijn opgenomen, voor derden en in de eerste plaats voor de kandidaat-overnemer een res inter alios acta uitmaken: het bestaan van de overeenkomst moeten zij erkennen, maar de inhoud ervan niet. ${ }^{153}$ Met andere woorden, de kandidaat-overnemer wordt geldig aandeelhouder, ook als hij de conventionele overdrachtsbeperking heeft miskend. De vennootschap heeft overigens geen rechtsgrond om hem als aandeelhouder te weigeren. De benadeelde contractspartij moet zich dus tevreden stellen met plaatsvervangende schadeloosstelling (in voorkomend geval berekend zoals in tempore non suspecto contractueel vastgelegd, en kan geen uitvoering in natura bekomen. Dat wordt maar anders als er sprake is van derdemedeplichtigheid aan contractbreuk, met andere woorden wanneer de derde op de hoogte is van het bestaan van de overeenkomst en bewust en actief heeft meegewerkt aan de schending daarvan. ${ }^{154}$ Dergelijke derde-medeplichtigheid wordt traditioneel gesanctioneerd met de nietigheid van de overdracht, waarna de kandidaat-verkoper, zo hij dat wenst, de aandelen terug kan te koop aanbieden, maar deze keer met naleving van het goedkeurings- of het voorkooprecht. Sommige auteurs gaan een stap verder door te betogen dat in geval van sanctionering van een met derde-medeplichtigheid miskend goedkeurings- of voorkooprecht de aandelen meteen moeten worden toegewezen aan de (voor het eerste geval bij veronderstelling wel goedgekeurde) kandidaat-koper, of in ieder geval, dat aan de begunstigde de kans wordt gegeven de voorkoop- of de goedkeuringsprocedure te doorlopen. Met andere woorden, de overnemer die de conventionele beperkingen poogt te negeren en wordt teruggefloten, mag in deze stelling niet inroepen dat, als hij deze conventionele verplichtingen moet naleven, hij geen verkopende partij meer is. ${ }^{155}$

Deze analyse wordt meteen heel wat dubbelzinniger als de vennootschap partij is tot de overeenkomst: de overeenkomst is haar dan inhoudelijk tegenwerpelijk. Moet zij dan, ook al zijn haar aandelen volgens de wet en haar statuten vrij overdraagbaar, de derde weigeren, op gevaar af zich schuldig te maken aan contractbreuk? Pleegt de vennootschap toch contractbreuk, is afdwingbaarheid in natura dan toch mogelijk? En wat als de vennootschap geen partij is, maar de overeenkomst wel kent: stelt zij zich bloot aan aansprakelijkheid wegens derde-medeplichtigheid aan contractbreuk door zich niet te verzetten tegen de overdracht? Deze vragen geven op zichzelf al aan dat de opname van de overdrachtsbeperkingen in de statuten leidt tot een veel

I53 Pattyn, Aandeelhoudersovereenkomsten, nr. I52, p. II3 en de verwijzingen. Zie ook K.G. Kh. Gent I4 november I997, TRV I998, 54, noot.

I54 Voor de leer van de derde-medeplichtigheid, zie L. Cornelis, Algemene theorie van de verbintenis, nr. 302, p. 375; Van Gerven en Covemaeker, Verbintenissenrecht, p. I54-I55. In de praktijk voorzien overeenkomsten dan ook vaak in de contractuele verplichting van de kandidaat-overlater om kandidaat-overnemers in kennis te stellen van de inhoud van de overeenkomst. Erg effectief is deze clausule niet, omdat ze bij miskenning tot hetzelfde resultaat leidt; ze benadrukt alleen nog sterker de contractuele aansprakelijkheid van de overdrager.

I55 Vgl. Pattyn, Aandeelhoudersovereenkomsten, nr. I6I, p. I20-I2I en de verwijzingen. 
zuiverder situatie. Ook een conventionele beperking die bewust en uitdrukkelijk tegen de statutaire bepalingen ingaat (omdat ze strenger dan wel minder streng is), en waarbij de vennootschap partij is, plaatst haar in een moeilijke positie. Het komt ons voor dat de vennootschap opnieuw niet het recht heeft haar statuten te negeren als de belangen van derden op het spel staan. De aandeelhouders die geen partij zijn tot de overeenkomst kunnen derden zijn, maar ook de overnemer van de aandelen als hij te goeder trouw is, of de schuldeiser van een aandeelhouder. Ook dat wijst op een intuïtieve voorkeur voor opname in de statuten. Nochtans wordt dat aanvoelen niet door iedereen gedeeld. ${ }^{56}$

Een minderheidsstrekking in de rechtsleer trekt deze analyse immers zonder meer door naar de statutaire overdrachtsbeperkingen: ${ }^{157}$ de overnemer moet als aandeelhouder worden aanvaard, zelfs tegen een niet-nageleefde statutaire overdrachtsbeperking in, tenzij hij derde-medeplichtig is aan de miskenning van de statuten door de overdrager. In de 'harde' visie wordt het bewijs van derde-medeplichtigheid niet geleverd door het bestaan van de statutaire clausules, maar moet er een bijkomend bewijs van derde-medeplichtigheid voorhanden zijn. In een 'zachtere' visie mag van de derde-overnemer in alle redelijkheid worden verwacht dat hij de statuten raadpleegt alvorens te kopen, zodat zijn kwade trouw wordt vermoed..$^{158}$

De meerderheidsstrekking hecht terecht wel een afzonderlijk belang aan de opname in de statuten (zie ook hiervoor, nr. 5), zij het dat er geen eensgezindheid bestaat over de grondslag van deze tegenwerpelijkheid: sommigen wijzen op het herwonnen intuitu personae-karakter van de met de overdrachtsbeperkingen belaste effecten; anderen steunen op de algemene vennootschapsrechtelijke regels inzake tegenwerpelijkheid van bekendgemaakte statuten zoals neergelegd in artikel 76 W.Venn., ${ }^{159}$ maar de strekking die de bovenhand lijkt te hebben gehaald is de toekenning, naar Nederlands voorbeeld, van een zakenrechtelijke werking aan de statuten. ${ }^{60}$ De

I56 Voor een overzicht van de aanhangers van de verschillende stellingen en hun evolutie (voornamelijk van de stelling die de tegenwerpelijkheid aanvaardt: alleen statutaire goedkeuringsclausules of ook voorkooprechten; alleen aandelen op naam of ook toonder; daarmee samenhangend: wel of niet voor genoteerde vennootschappen), zie M. Wyckaert, 'Overdrachtsbeperkingen en stemrecht', in: De nieuwe vennootschapswetten van 7 en 13 april 1995, Kalmthout: Biblo I995, nr. I6, p. Io6-Io8; Braeckmans en Houben, Handboek vennootschapsrecht, nr. 928, p. 499; Pattyn, Aandeelhoudersovereenkomsten, nr. I53-I55, p. II3-II7.

I57 H. Laga, 'Het leerstuk van de derde-medeplichtigheid aan andermans contractbreuk toegepast op de schending van statutaire aanvaardings- en voorkoopprechten', noot onder Kh. Namen 22 februari I990, TRV I99I, 234 (vonnis dat zich deze analyse eigen maakt).

I58 D. Van Gerven, 'Kroniek vennootschapsrecht 2005-06', TRV 2006, p. 529, nr. 57; zie verder ook de verwijzingen bij Pattyn, Aandeelhoudersovereenkomsten, nr. I54, p. II6.

I59 Daarover: M. Van Gils, 'Derdentegenwerpelijkheid van akten van een NV', TRV 2004, p. 705 e.v.

I60 K. Geens, 'L'opposabilité d'une clause statutaire d'agrément ou de préemption', in: Liber Amicorum Commission Droit et Vie des Affaires, Brussel: Bruylant I998, 50I4, nr. II; K. Geens, M. Denef, F. Hellemans, R. Tas en J. Vananroye, 'Overzicht van rechtspraak - Vennootschappen (I992-98)', TPR 2000, p. 4I6, nr. 402; Braeckmans en Houben, Handboek vennootschapsrecht, nr. 929, p. 501. Ook deze strekking vindt bevestiging in één beschikking (K.G. Kh. Gent I4 november I997, TRV I998, 54, noot: dit geval betrof een conventionele aanvaardingsclausule, die de rechter niettegenwerpelijk aan de vennootschap verklaarde, maar hij gaf aan dat hij anders zou hebben geoordeeld mocht de clausule statutair zijn geweest). 
overnemer wordt dan niet erkend als aandeelhouder in de vennootschapsrechtelijke verhouding; in zijn relatie met de overdrager wordt hij croupier (ondervennoot) (artikel 38 W.Venn.), ${ }^{161}$ tenzij hij de overeenkomst nietig laat verklaren, bijvoorbeeld omdat hij kan aantonen dat zijn toestemming is aangetast door een wilsgebrek (vgl. echter hiervoor, nr. 48), of uitsluitend vervangende schadeloosstelling vordert.

I6I K. Geens, 'De derdemedeplichtigheid is overbodig om miskenningen van statutaire aanvaardings- en voorkooprechten te sanctioneren', TRV, 2006, p. 70; Braeckmans en Houben, Handboek vennootschapsrecht, nr. 929, p. 50I; Pattyn, Aandeelhoudersovereenkomsten, nr. I57, p. II9. 